UNIVERSIDADE DE SÃO PAULO

FACULDADE DE EDUCAÇÃO

DANIEL ROMÃO DA SILVA

Educação Matemática: equidade e legitimação

SÃO PAULO-SP

2019 
DANIEL ROMÃO DA SILVA

Educação Matemática: equidade e legitimação

Versão corrigida

Tese apresentada ao Programa de Pós-graduação em Educação da Faculdade de Educação da Universidade de São Paulo para obtenção do título de Doutor em Educação.

Linha de pesquisa: Ensino de Ciências e Matemática

Orientador: Vinício de Macedo Santos

SÃO PAULO-SP 
Autorizo a reprodução e divulgação total ou parcial deste trabalho, por qualquer meio convencional ou eletrônico, para fins de estudo e pesquisa, desde que citada a fonte.

Catalogação da Publicação

Ficha elaborada pelo Sistema de Geração Automática a partir de dados fornecidos pelo(a) autor(a)Bibliotecária da F E/USP: Nicolly Soares Leite - CRB-8/8204

Re Romão da Silva, Daniel
Educação Matemática / Daniel Romão da Silva;
orientador Vinício de Macedo Santos. -- São Paulo,
$2019.7 \mathrm{p.}$
167 .
Tese (Doutorado - Programa de Pós-Graduação
Educação Científica, Matemática e Tecnológica) --
Faculdade de Educação, Universidade de São Paulo,
2019.
1. Educação Matemática. 2. Discurso. 3. Equidade.
Muducação Para Todos. 5. Organizações
II. Título.


Nome: SILVA, Daniel Romão da

Título: Educação matemática: equidade e legitimação

Tese apresentada à Faculdade de Educação da Universidade de São Paulo para obtenção do título de Doutor em Educação.

Aprovado em:

\section{BANCA EXAMINADORA}

Prof. Dr. Vinício de Macedo Santos (presidente)

Instituição: FEUSP. Assinatura:

Prof. Dr. Carlos Roberto Vianna

Instituição: UFPR. Assinatura:

Prof. Dr. Antônio José Lopes

Instituição: CEM. Assinatura:

Prof. Dr. Alexandre Silva

Instituição: IFSP. Assinatura:

Prof. Dr. José Carlos Oliveira Costa

Instituição: CUFSA. Assinatura: 


\section{RESUMO}

A presente tese aborda os desdobramentos para o ensino de matemática dos discursos sobre equidade presentes nos documentos oficiais produzidos pela UNESCO e por outras organizações multilaterais durante a década de 1990. A agenda internacional estabelecida por tais documentos assumiu o lema "educação para todos" como sua principal marca e se ajustou às políticas neoliberais de reestruturação da ordem mundial e ao contexto da globalização. De modo a analisar os referidos discursos, primeiramente foram discutidos os conceitos de igualdade e equidade, assim como sua utilização nos discursos educacionais, particularmente como herança da própria consolidação da escola pública burguesa nos séculos XVIII e XIX. Em seguida, com base no referencial teórico da Análise Crítica do Discurso, foram analisados os principais marcos oficiais da educação para todos, com destaque à Declaração Mundial de Educação para Todos (1990) e, no âmbito nacional, o Plano Decenal de Educação para Todos (1983) e os Parâmetros Curriculares Nacionais (1997 e 1998). Finalmente, foram discutidos uma série de perspectivas teóricas em Educação Matemática que poderiam representar contrapontos ao discurso hegemônico no sentido de promover maior igualdade no acesso ao ensino de matemática.

Palavras-chave: Equidade, análise crítica do discurso, educação matemática, educação para todos. 


\begin{abstract}
The present thesis deals with the implications for the teaching of mathematics of the discourses on equity presented in official documents produced by UNESCO and other multilateral organizations during the 1990s. The international agenda established by such documents has assumed the theme of "education for all" as its main element and conformed to the neoliberal policies of restructuring the world order and the context of globalization. In order to analyze these discourses, the concepts of equality and equity were first discussed, as well as their use in educational discourses, particularly as inheritance of the very consolidation of the bourgeois public school in the eighteenth and nineteenth centuries. Then, based on the theoretical framework of Critical Discourse Analysis, the main official milestones of education for all were analyzed, with emphasis on the World Declaration of Education for All (1990) and, at the national level, the Ten Year Plan of Education for All (1983) and the National Curricular Parameters (1997 and 1998). Finally, a series of theoretical perspectives in Mathematics Education were discussed that could represent counterpoints to the hegemonic discourse in order to promote greater equality in the access to mathematics education.
\end{abstract}

Keywords: Equity, critical discourse analysis, mathematical education, education for all. 


\section{LISTA DE SIGLAS}

BM - Banco Mundial

ENEM - Exame Nacional do Ensino Médio

FEUSP - Faculdade de Educação da Universidade de São Paulo

IBE - Bureau Internacional de Educação

ICME - Congresso Internacional de Educação Matemática

NEBA - Necessidades Básicas de Aprendizagem

OCDE - Organização para a Cooperação e Desenvolvimento Econômico

ONU - Organização das Nações Unidas

PISA - Programa Internacional de Avaliação de Estudantes

PNUD - Programa das Nações Unidas para o Desenvolvimento

Saeb - Sistema de Avaliação da Educação Básica

UNESCO - Organização das Nações Unidas para a Educação, Ciência e Cultura

UNICEF - Fundo das Nações Unidas para a Infância 
SUMÁRIO

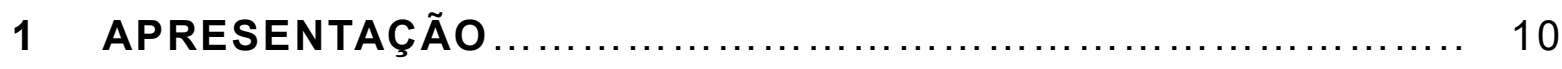

2 CONCEPÇÕES DE IGUALDADE E EQUIDADE NOS DISCURSOS EDUCACIONAIS ............................... 24

2.1 Universalização do ensino e consolidação da escola pública burguesa

2.2 Sobre os conceitos de igualdade e equidade ................... 35

2.3 Discursos sobre equidade e educação.......................... 43

2.4 Discursos sobre matemática, escola e equidade................ 50

3 ANÁLISE DOCUMENTAL: DISCURSOS SOBRE EQUIDADE, EDUCAÇÃO E MATEMÁTICA NAS POLÍTICAS PÚBLICAS

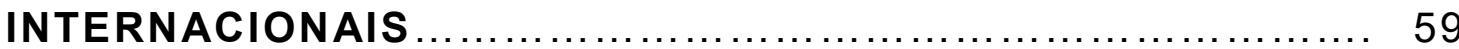

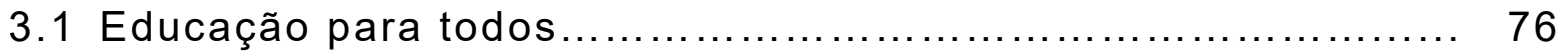

3.2 Educação para todos e as políticas educacionais brasileiras......................................................... 95

3.3 Educação para todos e o ensino de matemática ........................................................ 102

4 EDUCAÇÃO MATEMÁTICA: CONTRAPONTOS AO DISCURSO

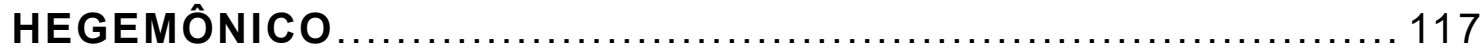


4.1 Aprendizagem situada....

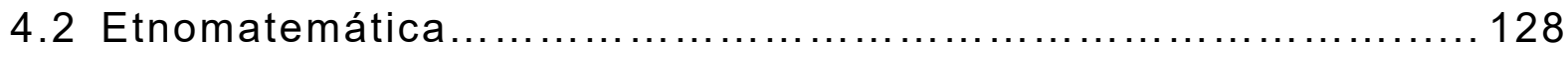

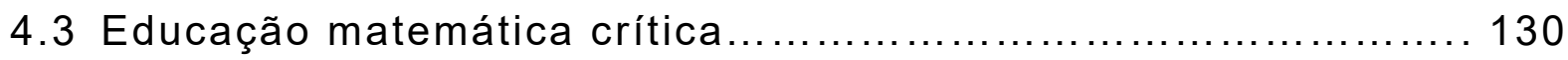

4.4 Educação matemática culturalmente relevante .................... 136

4.5 Educação matemática realística.................................. 138

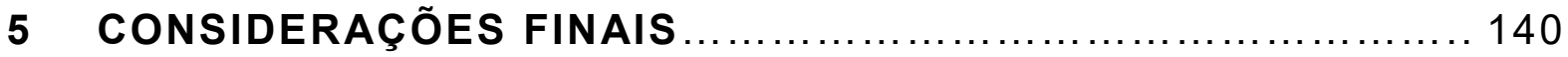

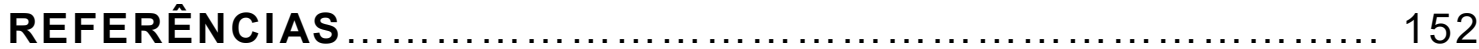




\section{APRESENTAÇÃO}

A presente tese, desenvolvida junto ao programa de pósgraduação da Faculdade de Educação da Universidade de São Paulo (FEUSP), é fruto de uma série de inquietações provenientes de minha experiência pessoal como professor de matemática e educador social, entre os anos de 2004 e 2017, tanto em escolas municipais e estaduais, quanto em organizações não governamentais, em ambas as situações, trabalhando com crianças e adolescentes residentes em bairros periféricos e favelas na cidade de São Paulo. Ao longo deste período, tive a oportunidade de desempenhar funções e papéis diversos, desde o trabalho de sala de aula, até formação de professores, produção de materiais didáticos, coordenação pedagógica e direção. Como educador em uma organização não governamental, pude explorar a matemática num contexto de ensino não formal, assim como me aproximar mais do cotidiano extraescolar dos alunos, de suas famílias e da comunidade em que vivem de modo geral.

A noção de inquietação, proposta por Innerarity (2007), expressa pertinentemente as questões, contradições e reflexões surgidas ao longo deste percurso, assim como a forma como eu, na condição de professor, educador e pesquisador, me relacionei com as mesmas. Segundo tal perspectiva, a inquietação se desdobra como fruto do espanto para com o mundo, manifestada através do desassossego e que, quando colocada em prática, dá origem a perguntas sobre as razões de ser e de existir de determinados fatos e objetos.

Entendidas dessa forma, tais inquietações, em grande parte, se originaram da multiplicidade de discursos que permeiam tanto o ensino de matemática, quanto a educação em seu sentido mais amplo. São discursos veiculados pela mídia, estão presentes nas falas cotidianas dos indivíduos, são objetos de pesquisas acadêmicas e, em determinados casos, estão institucionalizados em documentos oficiais e 
políticas públicas.

Desta multiplicidade de discursos e das formas com que estes circulam, destaco um conjunto particular de temas que aponta para algumas das principais inquietações em torno das quais esta tese foi articulada: i. a essencialidade da educação para o progresso da sociedade e do indivíduo; ii. a educação vinculada à formação para a cidadania; iii. a relação entre educação, inserção no mercado de; iv. e, como um desdobramento deste último, a educação como forma de mobilidade social.

Por um lado, esta temática, por si só, se configurou no campo pessoal das inquietações, principalmente pela redução com que encarava problemas como a pobreza, o reconhecimento, a participação dos indivíduos na sociedade, ou a relação entre formação para o trabalho e mobilidade social. Nesse sentido, destes temas emanam narrativas sobre a educação como elemento necessário para a transformação do indivíduo em cidadão e, desse modo, inserido num contexto de direitos e deveres, de normas morais e jurídicas e de regras sociais diluídas nas relações cotidianas. Estas narrativas, ao entender a educação como crivo entre o cidadão e o "não cidadão", legitimam a exclusão dos "não educados"; e, ao assumir a mobilidade social como propósito da educação, naturalizam a existência das desigualdades sociais e posicionam a educação segundo uma lógica meritocrática.

Por outro lado, o grande desassossego com que me defrontei foi a naturalização destes discursos no cotidiano escolar nas vozes de gestores, professores, alunos e familiares, assim como a forma com que se apresentam em documentos oficiais e materiais didáticos.

Assim, uma primeira hipótese reside no fato de que tais discursos se tornaram de tal forma naturalizados e esvaziados de significado que, 
em certa instância, constituíram um falatório, segundo a concepção de Heidegger (2005), ou seja, um repetir e passar adiante sem um esforço real ou genuíno em efetivamente dizer aquilo sobre que se fala. Tratase de um falar vazio, sem originalidade, um falar cujo conteúdo é o já dito e repetido de tantas e inúmeras formas, que se torna indiferente a quem escuta (HEIDEGGER, 2005; DUARTE, 2007). Em outra instância, é possível entender que tal discurso circula ao nível do senso comum, no sentido do termo atribuído por Santos (2010, p.32), como um "conhecimento evidente, que pensa o que existe tal como existe e cuja função é a de reconciliar a todo custo a consciência comum consigo mesma". Não se trata do resultado de uma prática explicitamente intencional, mas sim das próprias interações cotidianas, reproduzindose no contexto social, inspirando segurança e confiança para aqueles nele inseridos e, por esse motivo, privilegiando ações que não acarretam em rupturas significativas nem no contexto, nem em sua própria existência.

Outra hipótese, levantada por Charlot (2000, 2013a), se orienta no sentido de que, dada a aparente evidência e aceitação social destes discursos, por um lado, eles poderiam se configurar apenas como objetos sociomidiáticos, por outro, poderiam cumprir a função de apaziguar disputas e as aspirações de determinados grupos ao testemunharem suas bandeiras empunhadas, sem necessariamente refletir numa contemplação imediata ou efetiva destas demandas. Nesse sentido, Dagnino (2004) sinaliza para como o neoliberalismo, se apropria de forma perversa de uma série de discursos, remodelando-os e adequando-os a sua própria lógica e propósito.

Tais hipóteses não são excludentes entre si ou contraditórias. O ponto de toque entre elas é justamente a forma como os discursos são apropriados, interpretados, reinterpretados e utilizados. Nesse sentido, seja como forma de apaziguamento, de apropriação perversa, de falatório ou de senso comum, tais discursos se articulam em torno de 
discurso hegemônico sobre a função social da educação. Vale ressaltar que tal hegemonia não significa unicidade, ou seja, existem outros discursos, alguns que se complementam, enquanto outros que se opõem. Inseridos nesta arena de disputas, eventualmente um destes discursos se sobrepõe e assume a liderança em relação aos demais, estabelecendo uma condição hegemônica.

Segundo Apple (2001), isso não ocorre necessariamente pela via da coerção, mas pela obtenção de um consenso segundo o qual os demais grupos se alinham, mesmo não concordando plenamente.

A chave para isso é chegar a um compromisso de tal forma que esses grupos sintam como se as suas preocupações estivessem sendo ouvidas (...), mas sem que os grupos dominantes tenham de abrir mão de sua liderança em relação às tendências gerais da sociedade (APPLE, 2001, p.43).

Tal discussão elucidou parte das inquietações, mas trouxe à luz outras: de quem são as vozes preponderantes nestes discursos? É possível determinar seus autores? Existiriam interesses ocultos nestes discursos? Quem seriam seus beneficiários? Os efeitos e resultados destes discursos, quando transformados em políticas públicas, seriam exatamente os esperados, dadas as concepções sobre as quais foram amparados? Mais especificamente, qual o papel assumido pelos discursos sobre a matemática neste contexto?

O ensino de matemática, inserido nesta lógica, se alinha com os temas apresentados e reforça o discurso hegemônico: é essencial para o desenvolvimento tecnológico e progresso da sociedade; é importante na formação do cidadão, tanto para atuar em uma sociedade baseada na computação e informática, quanto para utilizar a matemática como recurso de análise e resolução de problemas cotidianos; por fim, fundamental para preparar os indivíduos para avaliações, exames vestibulares e processos de seletivos, uma vez que a matemática figura 
com uma posição privilegiada dentro destes instrumentos; em outras palavras, o ensino de matemática exerce também um papel fundamental no jogo meritocrático.

Segundo Skovsmose e Valero (2002), a partir deste cenário, o ensino de matemática precisa dialogar com dois paradoxos: da inclusão e da cidadania. O paradoxo da inclusão se refere ao fato de que é inerente à ideia de incluir, o estabelecimento de uma norma ou um estado ideal segundo o qual o indivíduo precisa se adequar para que seja entendido como incluído. Se entendermos como norma o aprendizado de um determinado conjunto de conteúdos, oficializado por orientações e diretrizes curriculares, livros didáticos, matrizes de macroavaliações e vestibulares, então aqueles que não aprendem matemática estão fora da norma, são uma abjeção (POPKEWITZ, 2010). Assim, a retórica da inclusão incorpora em si a exclusão daqueles que são distantes da norma (POPKEWITZ, 2004, 2010). O paradoxo da cidadania, por sua vez, se refere ao fato de que, enquanto o ensino de matemática se volta a responder as aspirações e necessidades da "sociedade da informação" ou do "mundo do trabalho", o próprio ensino se reduz a uma simples adaptação às demandas sociais vigentes. Assim, por um lado postula a preparação do indivíduo a uma participação cidadã ativa, por outro, assegura a sua adaptação a uma dada ordem social que, em muitos casos, configura-se de forma excludente.

Entretanto, o ensino de matemática não somente reitera e reinterpreta muitas das narrativas citadas, como também agrega outras, constituídas da própria especificidade da matemática e de sua história. A exemplo do realizado no caso da educação, agrupamos algumas destas narrativas a partir de temas centrais: i. a matemática revestida de idealidade e intangibilidade; ii. a matemática como descoberta e não como invenção humana; iii. a supervalorização da matemática em relação a outros conhecimentos e disciplinas no âmbito dos currículos 
escolares.

As origens deste discurso se encontram diluídas ao longo de sua própria construção histórica; contudo, a influência do pensamento grego clássico, particularmente de Platão e Aristóteles, pode ser demarcada como um aspecto fundamental de sua constituição. A idealidade com que, particularmente, a concepção platônica revestiu a matemática, segundo Foucault (2008, p.211), "se desenrolou ao longo da história e só foi questionada para ser repetida e purificada".

Sumariamente, a partir do século XVIII, filósofos iluministas como Diderot, D'Alambert, Condillac e Condorcet, mesmo dispondo de olhares e concepções diferentes, recuperaram este discurso e, conferiram à matemática um lugar privilegiado dentre os demais conhecimentos, assim como em seus projetos de instrução pública (GOMES, 2008). Após a Revolução Francesa, a matemática toma parte no jogo meritocrático, sendo assumida como critério de seleção em universidades e em postos do mercado de trabalho (ROQUE, 2012). O positivismo utópico de Condorcet, no século XIX, propõe não somente a matemática acima das demais ciências, mas também como a forma ideal segundo a qual a própria sociedade deveria ser estruturada (LÖWY, 2010). O contexto da Revolução Industrial, por sua vez, encara a matemática segundo uma ótica mais vinculada à engenharia e ao desenvolvimento tecnológico (ROQUE, 2012), potencializando sua essencialidade para a indústria e ao progresso da própria sociedade.

Tal associação entre matemática, progresso e desenvolvimento tecnológico tornou-se constante ao longo dos séculos $X X$ e $X X I$, coincidindo com movimentos de renovação da matemática, como as propostas do grupo Bourbaki, que virão a repercutir no âmbito do ensino segundo o denominado Movimento da Matemática Moderna ${ }^{\text {. }}$

Segundo Kline (1976), o lançamento do Sputnik pelos soviéticos, em 1959, levantou uma série de especulações sobre a aparente superioridade dos russos 
Finalmente, nas décadas seguintes, a condição de essencialidade da matemática se renovou associada ao desenvolvimento do processo de globalização e da então denominada sociedade em rede ${ }^{2}$ (CASTELLS, 2005).

Deste amplo conjunto de narrativas e discursos que compõem o discurso hegemônico sobre as funções da educação e do ensino de matemática - tal qual descrito até este ponto - se originam também os discursos que representam as vozes daqueles que, por motivos diversos se encontram excluídos da educação formal ou, mesmo quando incluídos, não encontram nela condições apropriadas de permanência ou de qualidade; nem, em certos casos, de uma educação que satisfaça as expectativas ou que seja representativa e relevante para seu grupo social e cultural.

Desse modo, no interior do discurso hegemônico, surgem discursos sobre igualdade de oportunidades, acesso democrático, diversidade etc. Se por um lado, foi o referido discurso hegemônico que deu origem às primeiras inquietações, é sobre este segundo grupo que erigiram as principais inquietações em torno das quais a presente tese foi estruturada.

em matemática e física, provocando intensas discussões nos EUA acerca de um novo currículo de matemática, que mais tarde viria se consolidar no Movimento da Matemática Moderna.

2 O "termo sociedade em rede" foi assumido como alternativa aos termos "sociedade de informação" ou "sociedade do conhecimento", segundo a perspectiva de Castells (2005, p.17), uma vez que "conhecimento e informação sempre foram centrais em todas as sociedades historicamente conhecidas". A inovação do fim do século $X X$ se deve ao fato de que o conhecimento e a informação passaram a se basear na computação e nas redes de informação, como a internet. 
Mais especificamente, as inquietações surgiram a partir das concepções de igualdade adotadas nestes discursos: ora tratada de modo amplo e abstrato (como uma igualdade plena ou absoluta), ora associada a fins específicos (igualdade de oportunidades, igualdade de acesso, igualdade de voz, igualdade de decisão etc.), ora associada à justiça social sob a lente da equidade.

Segundo uma concepção de igualdade absoluta, quaisquer indivíduos devem ser tomados como estritamente iguais e entendidos dessa forma por qualquer regra de distribuição de benefícios ou de ônus. Ou seja, todos os indivíduos são iguais, devem receber os mesmos benefícios e se onerar da mesma forma. No entanto, este cenário só pode ser considerado igualitário em virtude da premissa da igualdade entre todos os indivíduos, ou seja, quando suprimidas todas as diferenças. Assim, este cenário não é igualitário na perspectiva de indivíduos que possuem (que julguem possuir ou que almejem possuir), condições, necessidades ou expectativas diferentes. Segundo Abbagnano (2007), a concepção clássica de equidade de Aristóteles propôs uma alternativa a este problema ao adicionar à igualdade o aspecto da justiça, entendida por ele como a distribuição de benefícios e ônus proporcionalmente ao mérito de cada indivíduo.

No entanto, a equidade conforme apresentada nos discursos atuais se aproxima da interpretação feita por John Rawls nos anos 1970. Segundo Riscal (2011), a concepção de equidade também incorporou a ideia de diferença, mas reformulou a ideia de justiça em termos de justiça distributiva. Ou seja, a distribuição de recursos deve ser proporcional às necessidades de cada indivíduo, objetivando, em última instância, a restituição (ou instituição, em certos casos) da condição de igualdade para aqueles em condições sociais desprivilegiadas. Assim, enquanto a igualdade pode ser entendida a partir da noção da exatidão ou da congruência, a equidade pondera a existência de diferenças e, propõe formas de compensá-las. 
No âmbito da educação, os discursos sobre equidade ganharam projeção internacional após 1990, com a publicação da Declaração Mundial sobre Educação para Todos: Satisfação das Necessidades Básicas de Aprendizage ${ }^{3}$, assinada na conferência de mesmo nome organizada pela a Organização das Nações Unidas para a Educação, a Ciência e a Cultura (UNESCO) na cidade de Jomtien, na Tailândia.

Apesar de expressar um clima de esperança na proximidade do novo milênio, com aspirações cosmopolitas e projeções sobre a sociedade da informação, uma das principais marcas da Declaração de Jomtien foi a consternação ante os efeitos negativos provocados, ou acentuados, pelo próprio processo de transformação capitalista em sua conformação global.

A Declaração de Jomtien se insere neste contexto, tanto envolvida pelos discursos sobre equidade, quanto os institucionalizando segundo uma agenda internacional para educação. Se por um lado, a sua publicação pode ser entendida como uma vitória dos movimentos sociais por justiça social e democratização, ocorridos desde as décadas de 1960 e 1970 (GATES, VISTRO-YU, 2003), por outro, é possível interpretá-la como uma solução estratégica adotada pelas grandes potências neoliberais, através de organizações multilaterais, no sentido tanto de apaziguar as pressões dos movimentos sociais e amenizar os efeitos negativos decorrentes das crises capitalistas, acentuados pelo próprio processo de globalização e pelas políticas neoliberais, quanto de posicionar a educação como um setor de interesse do capitalismo em sua forma global, imprimindo suas próprias lógicas de controle e intervenção.

Assim, neste contexto, organizações multilaterais como a UNESCO, o Banco Mundial e a Organização para a Cooperação e

3 Referida deste ponto em diante apenas por Declaração de Jomtien. 
Desenvolvimento Econômico (OCDE) passam a ser posicionadas como grandes referências mundiais para a educação, tanto no âmbito do estabelecimento de princípios e objetivos para a educação, quanto no controle e avaliação dos mesmos. Segundo Mota Jr. e Maués (2014), as propostas do Banco Mundial para a educação nos países periféricos incluíram a descentralização da gestão escolar ao mesmo tempo em que a centralização da avaliação dos sistemas escolares. É neste contexto em que são criados o Sistema de Avaliação da Educação Básica (Saeb), em 1990, o Exame Nacional do Ensino Médio (ENEM), 1998, e, no cenário internacional, o Programa Internacional de Avaliação de Estudantes (PISA), em 2000. Um resultado direto dessa política é o fato de que, na medida em que a responsabilização pelos resultados das avaliações recai diretamente sobre a instituição escolar, a descentralização na gestão estimula que as instituições captem recursos visando melhores resultados via parcerias público/privada.

Nesse sentido, as inquietações iniciais a que nos referimos se estabeleceram a partir de discursos dúbios sobre a função da educação e do ensino de matemática, oscilando essencialmente entre o par inclusão/exclusão. Tais discursos, no entanto, gozando de certo grau de evidência e aceitação social, passaram a criar narrativas que circulam tanto como falatório quanto como senso comum. A partir desta constatação, outras hipóteses surgiram, levando a entender que as origens das várias interpretações destes discursos poderiam ser devidas às próprias disputas segundo as quais os significados e concepções destes discursos eram negociadas até que se consolidasse um discurso hegemônico. As inquietações então passaram a se dirigir especificamente aos discursos sobre igualdade e equidade, uma vez que são centrais aos demais discursos. Por fim, constatou-se como a agenda política internacional sobre educação para todos, iniciada nos anos 1990 e encabeçada por agências multilaterais como a UNESCO, OCDE e Banco Mundial, não somente se configurou como uma estratégia de expansão e manutenção do próprio neoliberalismo, como 
também imprimiu na educação uma série de discursos. Sendo que, particularmente no caso da presente tese, foram centrais os discursos sobre equidade.

A partir deste cenário, assumimos três grandes hipóteses ou questões: (i) os discursos que se formalizam nos marcos legais e documentos oficiais representariam o discurso hegemônico sobre a educação e o ensino de matemática? (ii) Uma vez que tais marcos e documentos geram programas sociais e políticas públicas, em que medida estes discursos se inserem na lógica cotidiana da escola e influenciam o próprio discurso educacional? (iii) Entendendo como os discursos são produzidos e ressignificados a partir de todo um espectro de concepções, intenções, interesses, justificativas e disputas, ao menos parcialmente, o discurso hegemônico também seria construído no (e pelo) próprio cotidiano escolar?

Em vista destas questões, estabelecemos como o objetivo principal desta tese, a identificação de como os discursos sobre igualdade e equidade, presentes nas normativas internacionais propostas por organizações multilaterais como UNESCO, OCDE e Banco Mundial, são apropriados pelo ensino de matemática e se desdobram nos programas e propostas curriculares para a educação básica. Da mesma forma, buscamos compreender como os discursos sobre a identidade, função e status social da matemática influenciam e se fazem presentes nos próprios discursos sobre equidade.

Nesse sentido, consideramos como recorte nesta tese os documentos produzidos ao longo da década de 1990, mais especificamente entre 1990 (quando da publicação da Declaração de Jomtien) e 1998, (ano da publicação dos PCN para terceiro e quarto ciclos). Abaixo, segue discriminado o corpus que será objeto da análise: 
i. Declaração Mundial sobre Educação para Todos (1990);

ii. Declaração de Nova Delhi sobre Educação para Todos (1993);

iii.Plano Decenal de Educação para Todos (1993);

iv. Lei de Diretrizes e Bases da Educação Nacional (1996);

v. Parâmetros Curriculares Nacionais (1997 e 1998);

vi. Constituição da República Federativa do Brasil (1988);

vii. Matemática para Todos (1984).

Os documentos $i$ e ii foram utilizados na identificação dos discursos sobre equidade propostos por organizações como UNESCO e Banco Mundial. Os documentos iii, iv e $v$, por sua vez, foram importantes para entender como os discursos identificados em $i$ e ii se fizeram presentes na legislação e nas políticas públicas nacionais. Nesse âmbito, o grande marco nacional é a LDB (documento iv), no entanto será nos PCN (documento $v$ ) que foi possível ser identificado como o ensino de matemática assimilou tais discursos. Por fim, os documentos vi e vii foram utilizados de forma a complementar as análises dos demais documentos.

Assim, cumprimos também um objetivo parcial desta tese: a identificação dos discursos sobre equidade presentes nos documentos citados. Assim, esperamos obter um retrato sobre como a equidade é concebida no âmbito da educação, na década imediatamente antes da virada do milênio.

E esta tese foi desenvolvida segundo uma perspectiva teórica inscrita no âmbito da pesquisa qualitativa e estruturada como descrito a 
seguir.

O presente capítulo apresentou algumas das inquietações surgidas das várias interpretações, paradoxos e dualidades despertados dos discursos sobre a função social da educação, bem como o papel que o ensino de matemática assumiu neste ínterim. Foi também discutido como tais discursos se alinham com a lógica neoliberal presente nas agendas políticas educacionais dos anos 1990, concebidas segundo o lema "educação para todos". Desse modo, a partir da perspectiva da análise crítica do discurso (FAIRCLOUGH, 2012), foi proposta a identificação dos discursos sobre equidade presentes tanto nos documentos produzidos por organizações multilaterais como a UNESCO e o Banco Mundial, quanto a sua influência na legislação e nas políticas públicas nacionais. Foi proposta também a análise sobre como o ensino de matemática dialoga, se apropria e também influencia tais discursos.

O segundo capítulo abordou a constituição e a transformação dos discursos sobre igualdade e equidade, desde o processo de consolidação da escola pública burguesa nos séculos XVIII e XIX até as concepções neoliberais que orientaram a internacionalização das políticas públicas educacionais da década de 1990.

No terceiro capítulo é realizada a análise dos documentos referidos no capítulo de apresentação segundo a abordagem metodológica da análise crítica do discurso (FAIRCLOUGH, 2012). No capítulo, além de definir o próprio conceito de discurso, é descrita tal abordagem metodológica, assim como os critérios utilizados para a análise dos textos dos documentos. A estrutura deste capítulo se estabeleceu em torno de três grandes blocos temáticos: i. Os documentos internacionais sobre educação para todos; ii. A influência destes documentos na legislação e nas políticas públicas nacionais; iii. A apropriação dos discursos presentes nestes documentos pelos 
documentos sobre o ensino de matemática.

O quarto capítulo considerou a análise feita no capítulo anterior e propôs um olhar sobre algumas perspectivas teóricas da área de educação matemática que, de formas variadas, representam pontos de resistência ao discurso hegemônico presente nos documentos avaliados e anunciam alternativas, de fora do discurso hegemônico, para um ensino de matemática que não seja excludente. Assim, foram particularmente consideradas referências vinculadas às denominadas viradas social e sociopolítica da educação matemática (LERMAN, 2000).

Por fim nas considerações finais, são retomadas algumas das principais discussões realizadas ao longo dos capítulos de modo a refletir sobre possibilidades para a ressignificação dos discursos sobre equidade, educação e matemática para todos, assim como oferecer alternativas ao discurso hegemônico. 


\section{CONCEPÇÕES DE IGUALDADE E EQUIDADE NOS DISCURSOS EDUCACIONAIS}

Neste capítulo, discutiremos como os conceitos de igualdade e equidade são apropriados, veiculados e reinterpretados pelos discursos sobre educação.

Primeiramente, será delineado o contexto do desenvolvimento da escola pública nos séculos XVIII e XIX. Consideramos tal período um marco histórico para o tema, sendo palco de eventos determinantes da modernidade, como a Guerra de Independência dos EUA, a Revolução Francesa e a Revolução Industrial. Para além das implicações econômicas e geopolíticas, esse período representou a consolidação dos valores iluministas e liberais, assim como da afluência de uma série de discursos vinculados a tais valores, sendo particularmente importantes em nosso estudo, os discursos sobre equidade, igualdade e justiça.

Estabelecida esta discussão, nos distanciaremos do contexto da educação e realizaremos o levantamento e a análise de algumas concepções fundamentais sobre equidade, igualdade e justiça. Em seguida, nos reaproximaremos da educação para discutir tais conceitos segundo a perspectiva da escola e dos sistemas educacionais. Por fim, discutiremos como a matemática se insere neste contexto.

\subsection{Universalização do ensino e consolidação da escola pública burguesa}

Luzuriaga (1971) destaca a democratização do ensino - a partir da implementação da escola primária pública, universal, gratuita e obrigatória - como o elemento comum à grande parte das discussões sobre o caráter da educação nos séculos XIX e XX. 
Na obra "Sociedade sem escolas", publicada em 1971, Ivan Illich afirma que "a escola é o mais insidioso de todos os falsos serviços [públicos]" (ILLICH, 1985, p.72). Esta afirmação se justifica no contexto da obra a partir de uma equiparação alegórica com o sistema de rodovias:

\begin{abstract}
À semelhança das rodovias, a escola dá a impressão, à primeira vista, de estar aberta igualmente a todos os aspirantes. Mas, de fato, está aberta apenas aos que constantemente renovam suas credenciais. Assim como as rodovias dão a impressão de que seu atual nível de custo por ano é necessário para que as pessoas se possam locomover, assim também as escolas são consideradas essenciais para atingir a competência exigida pela sociedade que usa a moderna tecnologia. (...) As rodovias resultam de uma perversão do desejo e necessidade de locomover-se que se converte em demanda por um carro particular. As próprias escolas pervertem a natural inclinação de crescer e aprender, convertendo-a em demanda pela instrução. (...) O valor da escolarização de alguém está em função do número de anos e do custo da escola que frequentou. A lei não obriga ninguém a adquirir carro, mas obriga todos a irem à escola (ILLICH, 1985, p.72-73).
\end{abstract}

A linha de raciocínio proposta em lllich (1985) se direciona à crítica da escola institucionalizada, balizada pelo discurso tecnicista e a serviço da manutenção das hierarquias e ordens sociais. No trecho citado estão representadas uma série de concepções acerca das características e funções sociais da escola: sua suposta universalidade ("aberta igualmente a todos"), seus objetivos ("atingir a competência exigida pela sociedade"), sua obrigatoriedade e sua relação com o Estado ("[a lei] obriga todos a irem à escola"). Subentendida a tais concepções podemos destacar a função da escola, de herança republicana, para formação dos cidadãos, circunscrita no âmbito dos direitos e deveres.

De certo modo, muitas das características criticadas por Illich (1985), possuem suas raízes no próprio contexto da consolidação da escola pública burguesa nos séculos XVIII e XIX. Segundo Luzuriaga 
(1971), as origens da escola pública burguesa encontram-se intimamente relacionadas às transformações da sociedade ocidental durante a passagem para modernidade: consolidação dos estadosnacionais, evolução do capitalismo industrial, ascensão da burguesia liberal ao poder, assim como a influência das reformas religiosas.

O surgimento dos estados-nacionais ocorre cronologicamente de forma desigual, na medida em que as antigas relações feudais se enfraquecem, consolidando-se principalmente após as revoluções Americana e Francesa. O desenvolvimento da indústria e o crescente poder político e econômico da burguesia, assim como o declínio das monarquias absolutistas europeias, foram determinantes para a superação do modelo feudal. A própria unificação territorial era fundamental aos interesses burgueses: estabelecia não somente moeda e sistema de pesos e medidas comuns, como também uniformizava tarifas, impostos e pedágios cobrados por diferentes nobres, além de desestabilizar o protecionismo das corporações de ofício aos produtos locais. Com o avanço da industrialização, este processo se intensifica, posto que o volume e o fluxo de produtos aumentam vertiginosamente, tornando ainda mais imprescindível a fiscalização e proteção do mercado.

Contudo, segundo Petitat (1994) e Luzuriaga (1971), não bastava que os territórios se unificassem e estabelecessem suas fronteiras geográficas, era fundamental constituir-se como nação, coadunando, língua, costumes e tradições comuns. Em termos de econômicos e políticos, os novos estados-nacionais se fundaram sobre alicerces liberais e fisiocráticos, imbuídos da lógica do laissez-faire, evocando a liberdade de empreendimento e alçando ao protagonismo a concepção de direito natural de propriedade. Desse modo, a única forma de igualdade possível seria balizada segundo a liberdade de trabalhar, fazer uso, vender, adquirir e valorizar seus bens e riquezas. A desigualdade passaria a ser então justificada pela própria desigualdade 
das faculdades individuais em fazer um "bom uso" destas liberdades. O fundamento da justiça, por sua vez, passa a ser configurado de modo a garantir a aplicação destas leis naturais.

O Estado moderno se consolidou evitando tanto um extremo caracterizado pela total livre iniciativa, quanto o outro extremo, do Estado absolutista, devendo consequentemente considerar um meio entre os excessos de liberdade e de poder (CHIAPPIN E LEISTER, 2017). Nesta perspectiva, segundo Chiappin e Leister (2017), o Estado assume o papel de controle e de regulação, ou seja, no alinhamento entre os interesses da esfera privada com os interesses nacionais, ou da esfera pública. Assim, a natureza do Estado, "é a de ser governo representativo, uma nova forma de governança com fundamento na representação, por consentimento" (CHIAPPIN e LEISTER, 2017, p.119). Este, por sua vez, se constituiu numa forma de poder no sentido de que "a representação é uma faculdade artificialmente criada no indivíduo por meio do Estado, com a distribuição de direitos e obrigações, transformando o num sujeito de direitos e obrigações" (CHIAPPIN e LEISTER, 2017, p.119).

Do ponto de vista do cotidiano, da dinâmica da sociedade, o avanço da industrialização implicou uma vasta migração do campo para os centros industriais urbanos que, carentes estruturalmente, não comportavam tal população, restando para estas, condições morais e físicas degradantes. Os efeitos da industrialização, ainda que moldando a vida de todos, eram distribuídos desigualmente, restando à grande massa benefícios escassos.

Da análise do contexto da Inglaterra e País de Gales, por exemplo, Altick (1998) revela que durante a primeira metade do século XIX, a população local praticamente dobrou, sendo que na segunda metade do século, esse número mais do que triplicou. Porém, os benefícios da modernidade e da industrialização estavam longe de ser 
igualmente distribuídos. Segundo Altick (1998) - baseado nos resultados obtidos pelo economista inglês Dudley Baxter - por volta de 1867, retirando os dependentes (crianças muito pequenas, inválidos e velhos), esta população era composta por cerca de 200.000 pessoas pertencentes às classes altas e médias altas, em contraposição a 1.85 milhões de pessoas das classes médias e de 7.8 milhões de pessoas das classes trabalhadoras (ALTICK, 1998).

Cruickshank (1978) salienta especialmente a condição das crianças na Inglaterra no período de 1833 a 1864 . Historicamente, as crianças sempre trabalharam, ajudando os pais nos campos, nas casas, oficinas e nas manufaturas domésticas. No entanto, o intenso movimento migratório desencadeado pelo desenvolvimento dos centros industriais, agravou a situação de miséria e precarizou as condições de nas grandes cidades. Assim, segundo Cruickshank (1978), de modo a escapar da miséria, as próprias famílias passaram a demandar a presença cada vez mais massiva de crianças nas fábricas.

Em uma jornada de trabalho similar a dos adultos e recebendo um salário expressivamente menor, crianças de até sete anos de idade eram empregadas especialmente na indústria têxtil, esgueirando-se dentro de máquinas para verificar defeitos e falhas (CRUICKSHANK, 1978). Em 1833, é adotada na Inglaterra a denominada Lei da Fábrica, que considerava a obrigatoriedade de frequentar a escola como condição para que crianças fossem empregadas. A lei também proibiu o emprego de crianças com menos de nove anos na indústria têxtil e restringiu a jornada de trabalho para crianças de até treze anos à quarenta e oito horas semanais (CRUICKSHANK, 1978). As crianças operárias deveriam dedicar ao menos doze horas semanas à escola, além da jornada de trabalho (CRUICKSHANK, 1978).

Neste cenário surgem questionamentos sobre suas próprias condições de vida e de trabalho e, ainda que incipiente, uma 
consciência de classe. Por outro lado, a ascensão dos partidos liberais ao poder, almejando a ampliação de sua influência e o apoio das massas, lança também as bases para o moderno estado de bem estar social. A sociedade industrial foi sintetizada por Aron (1981, p.73-75) em cinco características principais:

Inicialmente, observa-se que a empresa está radicalmente separada da família. (...) Em segundo lugar, a empresa industrial introduz um modo original de divisão do trabalho. Efetivamente, ela implica não só a divisão que existiu, em todas as sociedades, entre os setores da economia (entre os camponeses, os comerciantes e os artesãos), mas um tipo de divisão interno à empresa, uma divisão tecnológica do trabalho. (...) Em terceiro lugar, a empresa industrial supõe uma acumulação de capital. A civilização industrial exige que cada trabalhador utilize grande capital e, que este se renove continuamente. (...) A partir do momento em que o trabalhador tem a necessidade de um capital muito grande e em vias de expansão, introduz-se uma quarta noção, a do cálculo racional. (...) Pode-se afirmar que toda sociedade industrial implica um cálculo rigoroso, sem o qual as perdas de recursos e de energia seriam imensas. (...) Por fim, a quinta característica das empresas industriais é a concentração dos trabalhadores no local de trabalho. Surge, então, o problema da propriedade dos meios de produção.

No entanto, segundo a perspectiva de Arendt (2007), a grande revolução da modernidade constituiu justamente naquilo que Aron (1981) sintetizou em sua terceira característica da sociedade industrial: o advento de outra concepção de riqueza, não mais relacionada estritamente a seu conceito mercantil, mas como capital, cujo fundamento é gerar mais capital. Quando a riqueza se transforma em capital, a propriedade privada entra no espaço do mundo compartilhado por todos; ou seja, a preocupação individual com a propriedade privada se transforma em preocupação pública (ARENDT, 2007). Isso implica que a propriedade privada perde o "sentido de lugar tangível possuído por uma pessoa na terra" (ARENDT, 2007, p.80), passando a ter na força de trabalho do homem sua maior expressão. 
Segundo a concepção de Arendt (2007), enquanto a esfera privada corresponderia à intimidade (aquilo que se deseja ocultar, que diz respeito apenas ao indivíduo) e à propriedade (no sentido das posses pessoais do indivíduo), a esfera pública se referiria ao que se torna acessível a todos, seja naquilo que pode ser visto ou ouvido, seja no próprio mundo compartilhado, comum a todos. A esfera pública torna-se então a esfera da decisão, da política republicana. Habermas (1990), por sua vez, considera a esfera pública não somente nestes termos, mas também como um local no qual os assuntos e questões, tanto do âmbito público quanto privado, são julgados e debatidos em direção a um consenso; mais ainda, a esfera pública assume o papel de mediação entre a sociedade e o Estado.

Gorz (2005, p. 34), por sua vez, salienta como o próprio conhecimento também é transformado em capital:

a história da industrialização pode ser lida como a história do divórcio crescente entre o desenvolvimento dos conhecimentos científicos e técnicos, por um lado, e a cultura comum do outro. (...) O conhecimento-técnico científico não apenas está do lado do capital como dominação e subsunção do trabalho vivo pela maquinaria; ele faz parte do capital fixo como meio de extorsão do sobretrabalho. Seus detentores, os engenheiros, estão expressamente e ideologicamente no campo dos proprietários do capital. (...) O conhecimento, nesse estágio, existe na cabeça dos oficiais de produção e nos meios de produção tangíveis como poder restritivo sobre o trabalho.

Uma vez que o conhecimento é entendido como capital, este deixa de ocupar espaço puramente no âmbito privado e assume cada vez mais participação na esfera pública. Contudo, o ensino até o século XVIII, mesmo quando organizado pelo Estado, estabeleceu-se majoritariamente sob a responsabilidade da Igreja ou de congregações religiosas, sendo destinado apenas a uma parcela restrita da população e, constituindo-se dessa forma, segundo interesses do âmbito privado. 
Analisando por este viés, a discussão sobre o acesso ao conhecimento e sobre outro modelo de escola tornou-se preponderante.

O novo planejamento social não era apenas do cuidado com o individual. Ele incorporava narrativas de salvação, de como o indivíduo era e deveria ser. O mundo anterior, herdado da providência divina e do status social, foi substituído por noções de agência humana, progresso e cultura cívica, dirigidas ao presente e não para o Além. A visão religiosa da salvação foi transformada em noções de razão, racionalidade e progresso. A pedagogia era para efetivar os modos de vida em que as obrigações pessoais, as responsabilidades e a disciplina estavam ligadas em noções de progresso e auto realizações narradas como princípios de uma democracia liberal participativa (POPKEWITZ, 2010, p.79-80).

Boto (2003, p.742) salienta que, em certa instância,

Tratava-se de dar conteúdo simbólico às subjetividades revolucionárias, as quais haviam lançado à luz a bandeira da equidade; pela igualdade das oportunidades sociais. Tal intuito deveria consubstanciar-se na organização de políticas públicas; muito especialmente das políticas públicas da escolarização.

Desse modo, coube à escola responder aos desafios postos pela modernidade e pela sociedade industrial. A educação das massas não se tratava apenas de produzir cidadãos letrados ou técnicos; passou a ser compreendida como uma prática do Estado, responsável pela produção da criança como sua futura cidadã (POPKEWITZ, 2010). Ressaltamos como a própria ideia de massa, na acepção de Hardt e Negri (2005, p.13), cuja essência repousa na indiferença e na constituição de um "conglomerado indistinto e uniforme", aponta para a concepção de equidade destacadas por Boto (2003). A citada organização das políticas públicas de escolarização inscreveu a noção de "todas as crianças" não somente como um "compromisso ético", mas também como uma forma de apagar as diferenças (POPKEWITZ, 2010, p.90). 
Por uma série de razões a escola para as massas se apresentou numa posição privilegiada para efetivar tal proposta do Estado. Primeiro, por ser fundamental para a constituição de um sentimento nacionalista, em torno de cultura e língua comuns. Segundo Luzuriaga (1971), enquanto nos séculos precedentes a educação possuiu um caráter mais geral, no século XIX ela fica marcada pelo civismo e o patriotismo. Em certo nível, almejava-se alfabetizar a população e homogeneizar a língua falada e escrita dentro de cada território. Em outro nível, dos "já letrados”, era importante não somente o consumo, como também a produção literária e cultural.

O crescimento da população leitora e consumidora de livros e folhetins pode ser diretamente relacionado com o desenvolvimento dos sistemas públicos de ensino. Habermas (1990, n.p.) pondera que, na passagem para a modernidade,

Com um público generalizado de leitores, composto, sobretudo, por cidadãos burgueses, que ultrapassaram o círculo de eruditos, e que de tanto ler e reler intensivamente somente algumas obras clássicas, adapta doravante seus hábitos de leitura às novas publicações que aparecem forma-se quase que unicamente no seio da esfera privada uma rede relativamente densa de comunicação pública.

Todavia, acompanhando o referido desenvolvimento, tal esfera se amplia e extrapola os limites da burguesia. Conforme ressaltado por Altick (1998), foi principalmente dentre os trabalhadores um pouco mais qualificados (pequenos lojistas, balconistas e empregados domésticos) que se verificou o aumento de leitores.

Estas foram as pessoas que mais se beneficiaram da disseminação do ensino básico e cujas ocupações exigiam não só que eles fossem alfabetizados, mas que também mantivessem as suas faculdades de leitura. E também porque essas pessoas compartilhavam mais da prosperidade do século do que os trabalhadores não qualificados, garantindo-lhes uma melhor posição para comprar livros baratos e periódicos (ALTICK, 1998, p.83). 
Nesse contexto, ressalta-se o desenvolvimento do romantismo nas artes e na literatura, particularmente, tornando-se uma das grandes expressões da burguesia e um dos principais veículos para a divulgação de ideais republicanos e nacionalistas. Desse modo, Habermas (1990) discute como a influência da instrução burguesa e da literatura não somente altera a esfera pública, como também distingue uma esfera pública considerada como hegemônica de outra, entendida como uma esfera pública plebeia. No entanto, quaisquer destas esferas compartilhariam dos mesmos ideais básicos (essencialmente da visão liberal de sociedade, justiça e igualdade).

A segunda razão decorre desta primeira, estando intrinsecamente relacionadas: por se configurar num eficiente agente de doutrinação. Segundo Leonel (1994, p. 147):

Ao forjar o espírito revolucionário, foi preciso combater a religião do Estado para que os homens pudessem solucionar seus próprios problemas; para forjar o espírito contra-revolucionário, foi preciso obriga-los, por força da lei, a frequentar a escola pública. Por um lado, o indivíduo esta livre para, na vida privada, optar livremente por suas crenças, porém, na vida pública, deve-se configurar no projeto liberal de cidadão.

Assim, a educação para as massas se configurou numa potente ferramenta de persuasão e inculcação ideológica (PETITAT, 1994). Segundo Petitat (1994, p.144), “somente um raciocínio educado, esclarecido, poderia compreender o quanto é justo o direito de propriedade como fundamento de uma nova ordem social".

Finalmente, por seu papel específico na formação do operariado. Diferente das antigas corporações de ofício, a fábrica não era um lugar de formação, função que aos poucos vai sendo assumida pela escola. Sua importância, contudo, extrapola a formação instrumental ou técnica, mas garante também que o futuro operário também se atualize. Fato este de grande valor para a indústria, uma vez que a velocidade 
com a qual se modernizavam máquinas e equipamentos rapidamente tornavam obsoletos os trabalhadores, implicando, por um lado, o desperdício de mão de obra e, por outro, o aumento do número de desempregados e o aprofundamento da miséria e dos problemas sociais.

A partir destes variados papéis agregados pela escola é possível identificar duas propostas - ou interesses - distintas (os):

Paralelamente à implementação de um sistema estatal de ensino que tornasse a educação parte da esfera pública e não apenas da privada, mas afastando-se dos interesses unicamente religiosos, desenvolvia-se a discussão em torno da necessidade de desenvolver-se um ensino nacional, que tivesse por finalidade gerar na população o sentimento do civismo e do patriotismo, possibilitando a consolidação do Estado-nação através de laços mais fortes que os estritamente políticos (...). A conjunção desses dois processos - progressiva ingerência do Estado nas questões de educação e constituição de uma educação cívica que desenvolvesse o senso de nacionalidade - é a grande responsável pelos primitivos delineamentos do sistema de ensino público que perdura até nossos dias (GALLO, 2002, pp.127-128).

Segundo Gomes (2008), Condorcet também avaliou existência de uma dupla concepção: a educação nacional (cujo apelo maior está nos sentimentos, objetivando a formação moral e o sentimento de pertencimento à nação) e a instrução pública (focada no conhecimento, visando o desenvolvimento das faculdades intelectuais e aptidões técnicas). Desse modo, segundo Gomes (2008, p. 229-230),

Condorcet exclui da esfera pública essa noção de educação, considerando que cabe a cada cidadão dar a seus filhos a educação que desejar; o poder público ultrapassaria os limites de sua competência se pretendesse assumir uma formação moral com base nos sentimentos. Condorcet pensa, contudo, que os conhecimentos intelectuais são uma parte imprescindível no interior da formação moral e posiciona-se contrariamente a uma temática ordenada em um universo extra-racional. 
A existência destes múltiplos olhares sobre as funções e papéis a serem desempenhados pela escola ilustra como, desde sua gênese, a escola pública moderna esteve envolta em uma arena de disputas entre interesses conflitantes, especialmente pela expectativa nela depositada como um potencial agente capaz de moldar toda a sociedade. Mais ainda, a escola torna-se reconhecidamente vital para o funcionamento do projeto burguês e liberal de sociedade. Se, por um lado, ela é uma consequência deste projeto, por outro, o próprio projeto dela se torna dependente.

\subsection{Sobre os conceitos de igualdade e equidade}

Os conceitos de igualdade e equidade assumiram variadas interpretações ao longo da história, desde a concepção aristotélica, discutida brevemente no capítulo de introdução, até suas formulações modernas e contemporâneas. A seguir, discutiremos algumas destas concepções.

A igualdade pode ser compreendida a partir de uma formulação lógica, segundo a relação entre dois termos, na qual um possa ser substituído por outro num mesmo contexto sem que isso invalide esta relação (ABBAGNANO, 2007). Ou seja, se considerarmos a igualdade entre $A$ e $B$, qualquer condição ou relação entre $A$ ou $B$, implica sempre na mesma situação, uma vez que A e B são iguais.

Tal concepção é pertinente para verificar a igualdade de características físicas ou da distribuição de valores ou quantidades, assumindo, dessa forma, uma natureza descritiva, passível de ser verificada empiricamente. Um procedimento simples de contagem, por exemplo, permite verificar se as quantidades recebidas por dois indivíduos são iguais (BOBBIO, MATTEUCCI E PASQUINO, 1998). Assim, podem-se verificar isoladamente características físicas de coisas ou de pessoas e decidir se são ou não iguais. É o caso, por 
exemplo, da cor da pele, dos olhos, do sexo, da idade, da altura etc. É a partir deste raciocínio, por exemplo, que se justifica a impossibilidade de afirmar que duas pessoas são fisicamente iguais (BOBBIO, MATTEUCCI E PASQUINO, 1998). Elas podem possuir certas características físicas iguais, mas é impossível que haja igualdade absoluta de características físicas entre dois sujeitos. Para isso, a relação de igualdade precisaria ser verificada em todos os possíveis critérios, concluindo tautologicamente que o sujeito é ele mesmo.

Ao generalizar esta concepção para relações cotidianas, se uma determinada regra vale para um indivíduo, grupo ou classe, para que seja considerada igualitária, deveria valer da mesma forma para quaisquer substitutos (BOBBIO, MATTEUCCI E PASQUINO, 1998). Ou seja, se uma regra impõe determinado benefício ou ônus a um indivíduo, ela só será igualitária se qualquer outro indivíduo se beneficiar ou se onerar da mesma forma que o anterior. Dada a objetividade deste critério, não há abertura para interpretações ou dúvidas.

O mesmo já não pode ser verificado quando os critérios são relativos a regras sociais ou políticas. Se, por exemplo, os indivíduos $\mathrm{A}$ e $B$ recebem $\$ 1.000,00$ cada um por determinado serviço e $C$ recebe $\$ 500,00$ pelo mesmo serviço, o critério que verifica que as quantias de A e B são iguais e a de C é desigual em relação a estes, é empiricamente observável. Todavia, a regra que define que $C$ deve receber a metade do valor recebido por $A$ e $B$ é igualitária? Por esta definição de igualdade, $A$ e $B$ claramente não podem ser substituídos por C, logo, o tratamento recebido por C não é igual ao de A e B. Porém, se os critérios que definem as possibilidades de substituição se tornarem subjetivos, é possível entender esta regra como igualitária (BOBBIO, MATTEUCCI E PASQUINO, 1998). 
Assim, supondo que a regra que define que os valores a serem distribuídos entre A, B e C contempla o grau de formação técnica e propõe que os indivíduos de maior formação recebam mais, desde que estes critérios sejam observados, a regra é igualitária, já que o tratamento dado aos três indivíduos é imparcial (BOBBIO, MATTEUCCI E PASQUINO, 1998).

A partir destas considerações, o juízo sobre a igualdade se encontra implicado no tratamento a que os participantes de uma regra estão submetidos e nos critérios que definem as possibilidades de substituição entre os participantes desta regra. Além disso, é também importante discutir qual a relevância das características mobilizadas para determinar o tratamento dado em relação a certa regra. Por exemplo, características como idade e cidadania são relevantes em relação ao direito de voto, sendo então considerado igualitário limitar este privilégio em relação a estes critérios. Consequentemente, uma regra não é igualitária, quando se baseia em diferenças de características não relevantes, como sexo ou raça, no exemplo dado. No entanto, os juízos que estabelecem se tais características são ou não relevantes (ou ainda os subcritérios utilizados, como por exemplo, a idade mínima para o voto), são subjetivos, podendo se configurar como juízos de valor.

Um critério bastante defendido pelos anarquistas no século XIX propõe, segundo Bobbio, Matteucci e Pasquino (1998), que todos os benefícios ou ônus sejam distribuídos em partes iguais para todos. A partir deste critério, haveria um tratamento igualitário em relação ao consumo, à ocupação profissional, social e à educação, dissolvendo, consequentemente, as desigualdades das características pessoais.

Porém, segundo este critério, todas as regras seriam não igualitárias, uma vez que elas sempre se referem a benefícios ou encargos direcionados a determinadas pessoas ou grupos. Esse tipo de 
critério funciona bem em grupos reduzidos ou extremamente homogêneos. Em uma sociedade mais complexa e heterogênea, tais regras assumem a homogeneidade do todo e suprimem as diferenças pessoais e a diversidade. Fato este que por si só, já configura uma relação não igualitária.

Tal critério, resumido como "tudo para todos", contrapõe, em certa medida o critério de herança aristotélica no qual partes iguais devem ser distribuídas aos iguais. Ou seja, a exemplo dos limites do critério anterior, consiste em considerar somente uma parcela como o todo, mesmo que esta não represente nem mesmo a maioria. "Aos iguais" implica que tanto os benefícios quanto os ônus devem ser igualmente distribuídos entre aqueles que possuem alguma característica específica. Desta forma, este critério automaticamente autoriza um tratamento não igualitário aos não iguais (BOBBIO, MATTEUCCI E PASQUINO, 1998).

Assim, enquanto o primeiro propõe uma distribuição para todos e esbarra no limite da heterogeneidade da sociedade, resultando em regras não igualitárias, o segundo legitima a exclusão de um ou mais grupos ao considerá-los não iguais.

A solução, de inspiração iluminista, dada a esta situação implica que a distribuição de benefícios deve ser proporcional ao grau, não de uma característica qualquer estabelecida por uma regra, mas ao mérito. Ou seja, quanto mais uma pessoa merece, maior será a sua recompensa. Assim, a concepção de igualdade expressa num sistema meritocrático pode ser referida segundo a noção de que partes iguais são distribuídas a indivíduos de iguais merecimentos (BOBBIO, MATTEUCCI E PASQUINO, 1998). Contudo, o valor relativo da pessoa que recebe, ou seja, o grau do seu merecimento, é objeto de avaliação subjetiva e não de uma verificação objetiva (BOBBIO, MATTEUCCI E PASQUINO, 1998). 
Para tanto, um critério meritocrático não pode prescindir da noção de igualdade de oportunidades (BOBBIO, MATTEUCCI E PASQUINO, 1998). Ou seja, para que um indivíduo tenha a oportunidade de obter determinado benefício, não podem existir obstáculos em seu caminho para tal. Consequentemente, o sucesso na obtenção deste benefício depende apenas de sua habilidade natural ou adquirida, assim como de seu esforço. A igualdade, segundo este critério, só pode ser verificada se todos os indivíduos tiverem, primeiramente, seus caminhos livres de obstáculos e, depois, que os pontos de partida sejam os mesmos.

Nesse sentido, segundo Bobbio, Matteucci e Pasquino (1998), fazem-se necessárias distribuições desiguais para colocar todos ao mesmo nível de partida; devem-se distribuir privilégios jurídicos e benefícios materiais para os economicamente não privilegiados. Tal princípio, compreendido como nivelamento das oportunidades, está conexo com o princípio de nivelamento da satisfação das necessidades fundamentais (à vida, à liberdade e à propriedade, segundo o liberalismo clássico). Assim, abolidos os privilégios, nivelados os pontos de partida e estabelecida a igualdade de oportunidades, não haverá obstáculos para que cada um, segundo seu mérito, atinja a posição à qual sua capacidade plena lhe foi possível conduzir.

Segundo a perspectiva de Rawls (2000), em uma sociedade organizada democraticamente, há uma identidade de interesses em torno da cooperação entre os indivíduos que possibilita que cada um destes conquiste resultados e se desenvolvam mais do que se dependessem unicamente de seus próprios esforços. Porém, estabelece-se um conflito de interesses especialmente acerca da distribuição dos benefícios produzidos coletivamente. Em outras palavras, é necessário considerar critérios para avaliar se as regras de distribuição utilizadas são justas. 
Todavia, segundo Gutstein (2003) a demanda por justiça arriscase ser "egoísta", no sentido que os diversos grupos demandam justiça segundo seus próprios interesses e objetivos. Ou seja, a justiça na perspectiva de uns pode não somente ser conflitante com outros, como também gerar injustiça.

Rawls (2000, p.13) propõe que, desse modo, a sociedade precisaria estabelecer princípios de justiça que determinariam as regras e critérios de distribuição dos benefícios:

São esses princípios que pessoas livres e racionais, preocupadas em promover seus próprios interesses, aceitariam numa posição inicial de igualdade como definidores dos termos fundamentais de sua associação. Esses princípios devem regular todos os acordos subsequentes; especificam os tipos de cooperação social que se pode assumir e as formas de governo que se podem estabelecer.

É nesse sentido que Rawls (2000) assume a justiça como equidade, ou seja, os princípios de justiça passam a ser acordados em uma situação equitativa, assumidos, ainda que tacitamente, por todos.

\begin{abstract}
A justiça como equidade começa com uma das mais genéricas dentre todas as escolhas que as pessoas podem fazer em conjunto, especificamente, a escolha dos primeiros princípios de uma concepção de justiça que deve regular todas as subsequentes críticas e reformas das instituições. Depois de haver escolhido uma concepção de justiça, podemos supor que as pessoas deverão escolher uma constituição e uma legislatura para elaborar leis, e assim por diante, tudo em consonância com os princípios de justiça inicialmente acordados (RAWLS, 2000, p.14).
\end{abstract}

Dessa forma, Rawls (2000) considera que o entendimento da justiça como equidade implica uma concepção teórica contratualista, dada a pluralidade de interesses e reinvindicações conflitantes na escolha dos princípios de justiça.

Segundo Dubet (2004), partindo do contratualismo de Rawls, o 
princípio de justiça primordialmente escolhido pelas sociedades democráticas foi o mérito. Uma escolha justificada pelas próprias bases iluministas sobre as quais a sociedade burguesa se constituiu: por um lado, em contraposição aos privilégios nobres e clericais, era fundamental que desigualdades como as "de nascimento" fossem inaceitáveis; por outro, essa mesma proposta era interessante na perspectiva liberal, pautada pela livre concorrência e pelo acúmulo de capital. A meritocracia, desse modo, se configurou como um "modo de construir desigualdades justas, isto é, desigualdades legítimas" (DUBET, 2004, p. 544).

Em oposição à existência de uma teoria universal de justiça, Walzer (1983) a considera como criações situadas em determinados contextos políticos, históricos e sociais. Desse modo, diferentes comunidades teriam diferentes concepções de justiça. Para Walzer (1983) é o significado social e cultural dos bens produzidos nestas comunidades que determinam a distribuição justa dos mesmos, ou seja, diferentes bens sociais (como a educação, por exemplo) são distribuídos por diferentes razões, justificativas e procedimentos, sendo que tais diferenças derivam das próprias diferenças de entendimento acerca destes bens sociais, assumindo-os como produto de um particularismo histórico e cultural.

Nesta perspectiva, nas diferentes esferas da atividade social são criadas desigualdades próprias. Para Walzer (1983), as desigualdades não são consideradas problemáticas por si só, mas o são quando as desigualdades de uma esfera acarretam em desigualdades nas outras esferas. Segundo Dubet (2004), nesta concepção, um sistema justo é aquele que assegura certa independência entre as diversas esferas. Ou seja, entendendo a escola como uma esfera, desigualdades de renda, por exemplo, não deveriam desigualdades escolares. Assim, uma sociedade que oferecesse mais mobilidade e um maior número de oportunidades, seria possivelmente menos injusta, uma vez que as 
consequências das injustiças nas vidas dos indivíduos se diluiriam em face da maior quantidade de oportunidades (DUBET, 2004).

A despeito das diferenças entre ambas as concepções, tanto Walzer quanto Rawls propõem como forma de assegurar que qualquer sistema seja justo, o princípio de justiça distributiva (WALZER, 1983; RAWLS, 2000).

Para Walzer (1983), os bens precisam ser redistribuídos sempre respeitando seus significados e valores dentro de sua própria esfera, evitando, dessa forma, que bens distribuídos em uma esfera possam ser convertidos em bens de outras esferas, regidas por regras de distribuição distintas. Neste sentido a distribuição dos bens será focalizada na necessidade específica de cada indivíduo.

Para Rawls (2000), uma vez que cada instituição da sociedade possui a compreensão dos princípios de justiça que a regem e, dessa forma, também compreendem suas próprias funções, direitos e obrigações, os critérios de distribuição dos bens devem sempre ser orientados aos menos favorecidos. Segundo esta posição, denominada por Rawls como princípio da diferença, as políticas públicas nunca devem considerar as necessidades dos mais favorecidos em primeiro lugar. O Estado deve garantir que os bens primários (como educação, saúde etc.) sejam distribuídos a partir das necessidades dos menos favorecidos (RAWLS, 2000). A partir do princípio de igual distribuição das liberdades, Rawls (2000) cria condições para que os indivíduos acumulem bens materiais e sociais que os diferenciem dos demais, justificando que, a partir de políticas de tributação progressiva, por exemplo, parte desses bens possa ser redistribuída entre os menos favorecidos. No entanto, segundo Dubet (2004), ambas as concepções sempre enfrentam resistência por parte daqueles ao qual o modelo meritocrático puro assegura a reprodução de vantagens e privilégios. 
À luz de concepções como mérito, diferença, igualdade de oportunidades e justiça distributiva, discutiremos a seguir como a concepção de equidade é considerada nos discursos educacionais.

\subsection{Discursos sobre equidade e educação}

A escola nos séculos XVIII e XIX incorporou os discursos iluministas e liberais sobre equidade. Segundo Boto (2003), a proposta de Condorcet almejava, a partir de um projeto racionalmente projetado, constituir uma escolarização laica, gratuita, pública e universalizada, de modo a fazer justiça para as camadas menos privilegiadas. "Isso conduziria, progressivamente, à equalização das oportunidades de acesso à escola e, por decorrência, a uma diminuição, na ordem social, de clivagens postas pela desigualdade de fortunas" (BOTO, 2003, p.741).

Todavia, tais discursos, segundo Popkewitz (2010, p.78),

Nunca foram meramente sobre liberdade e inclusão. Eles foram gestos dúbios de esperança e medo, produzindo processos de exclusão com os de inclusão. Currículos e ensinamentos, por exemplo, diferenciavam a criança cosmopolita civilizada daquelas que, aparentemente, não incorporavam em si mesmas as características requeridas. As últimas eram crianças retardadas do início do século XX, que hoje são chamadas de imigrantes, em situação de risco ou socialmente menos favorecidas.

A universalização da escola propôs - ao menos idealmente - o encerramento das antigas relações sociais herdadas do feudalismo e do absolutismo ao equalizar todos os indivíduos em seu "ponto de partida". A partir deste princípio, seria promovida a "única desigualdade natural e, portanto, legítima: a desigualdade de talentos" (BOTO, 2003, p.742). Uma vez que todos possuem as "mesmas condições", a mobilidade social e as condições de vida passam a estar atreladas ao mérito individual, justificando e legitimando as desigualdades sociais decorrentes. 
A escola, nesse sentido, assumiu o papel de homogeneizar o entendimento de todos os indivíduos sobre os critérios de igualdade e princípios de justiça, ou seja, promover a equidade, segundo os termos de Rawls (2000). Além desse fato, a escola também se constituiu um papel chave no discurso meritocrático por ser entendida como elemento nivelador, condição para a igualdade de oportunidades.

Valle (2013, p. 292) salienta a influência do pensamento de Condorcet para tal afiliação da escola ao discurso meritocrático:

Condorcet (1743-1794), ao preconizar a difusão das "luzes" a todos, suscita a esperança de edificar um mundo melhor para toda a humanidade; um mundo constituído de cidadãos capazes de usar livremente o julgamento, de compreender e exercer seus direitos e de respeitar os de outrem. A conquista do direito à educação, afirma Condorcet, deve levar a perceber a "comum humanidade" e a aceitar o lugar na hierarquia das posições sociais que Ihe é devido, segundo o princípio da justa apreciação do mérito de cada um. É nesse quadro de reflexões que a igualdade e o mérito passam a figurar como princípioschaves à organização das sociedades, e o acesso de todos à instrução torna-se bandeira de luta dos mais variados movimentos revolucionários.

No entanto, segundo Dubet (2004), a igualdade de oportunidades sempre foi limitada, sendo que o "nascimento" não mais possuía o peso da herança da nobreza, mas sim o da herança do capital, como salientam Gates e Vistro-Yu (2003, p.33), "muitos vivem em uma sociedade injusta e desigual na qual o acesso à educação e à justiça depende do capital que se pode possuir e acumular". Nesse sentido, segundo a perspectiva apresentada em Walzer (1983), a injustiça ocorre pelo fato das desigualdades de uma esfera (do capital financeiro individual) criarem desigualdades em outras esferas (educação).

Para Dubet (2004, p.541),

Durante muito tempo, o mérito desempenhava um papel apenas marginal para os filhos dos trabalhadores e os 
"dotados" que podiam, graças ao sistema de bolsas, ter acesso ao antigo ginásio e, para uma minoria deles, chegar ao colegial. Mas, basicamente, cada categoria social estava vinculada a um determinado tipo de público escolar. Na verdade, a questão não era tanto criar um reino de igualdade de oportunidades, e sim permitir certa mobilidade social graças à escola para as classes médias e uma minoria do povo.

Desse modo, a consolidação da escola pública não tornou mais justa a sociedade porque reduziu as diferenças sociais, mas sim porque permitiu que, por meio da escola, todos os indivíduos entrassem na mesma competição (DUBET, 2004, p. 541), ainda que na prática, o tenha feito em condições desiguais. Nesse sentido, segundo DurutBellat (2005, p.28):

Não é, pois, de admirar que uma certa democratização da educação quase não tenha tido impacto sobre os fenômenos de reprodução social: certamente, a imobilidade social entre gerações é hoje um pouco menos forte que no início do século XX, e o desenvolvimento da instrução teve um papel quanto a isso, mas essa evolução não tem medida comum com o desenvolvimento da escolaridade (Vallet, 1999). Em outras palavras, a diminuição da desigualdade das oportunidades escolares foi mais nítida do que a diminuição da desigualdade das oportunidades sociais.

Apesar disso, o princípio meritocrático associado à equidade posicionou a escola também como elemento fundamental para mobilidade social. Associada à ideia de "competição" citada anteriormente, essa característica agregada pela escola é uma herança da própria sociedade industrial ao se constituir também como uma sociedade do desempenho, delegando ao indivíduo conquistar sua posição na sociedade, particularmente a partir da posição no mercado de trabalho ocupada por este indivíduo.

Em sua análise sobre as mudanças do capitalismo a partir dos anos 1990, Boltanski e Chiapello (2009, p.83) salientam a formação dos sucessores dos executivos e gestores como necessária à própria ampliação capitalismo: 
Esta tem o intuito de fornecer àqueles cujo engajamento é muito necessário à ampliação do capitalismo - sucessores dos executivos - evidências sobre as "boas ações" que devem ser realizadas, discurso de legitimação dessas ações, perspectivas estimulantes de auto-realização, possibilidade de projeção num futuro remodelado em função das novas regras do jogo e sugestão de novas vias de continuidade para os filhos da burguesia e de ascensão social para os outros.

Segundo Boltanski e Chiapello (2009), estabelece-se claramente a divisão de dois grupos ("filhos da burguesia" e os "outros"), aos quais também se destinam dois caminhos distintos ("continuidade" e "ascensão"). Na lógica meritocrática, ambas as posições são justas, já que todos tem o direito de querer ascender socialmente e, da mesma forma, manter as suas posições já estabelecidas. A injustiça cabe ao fato de que as condições para tal não são iguais.

Indiretamente, o acesso e a permanência na escola estariam então conectados à desigualdade social, uma vez que haveria uma conversão quase direta entre educação e capital econômico, deslocando, consequentemente, o significado da educação em termos de autodesenvolvimento, desenvolvimento intelectual e cultural em direção a instrumentalização para o mercado e, consequentemente, para a mobilidade social. É inegável que, numa sociedade capitalista regida por princípios meritocráticos de justiça e igualdade, a educação pode criar condições mais vantajosas para a obtenção de melhores posições no mercado de trabalho, da mesma forma que tal posição pode ser traduzida em vantagens financeiras e mobilidade social. Contudo, o determinismo sugerido por tal conversão possivelmente conduz a uma análise equivocada da realidade.

Skovsmose, Scandiuzzi, Valero e Alrø (2012), propõem um outro olhar sobre a questão da relação entre escola e mobilidade social, posicionando-a mais na perspectiva dos atores envolvidos. Segundo os autores, conscientemente ou não, as intenções que cada indivíduo carrega tanto para o seu envolvimento com a escola quanto para a 
própria aprendizagem dependem daquilo que ele interpreta como oportunidades possíveis, ou perspectivas cabíveis para sua vida, ancorado naquilo que é disponibilizado e percebido em seu contexto, ou seja, seu foreground. Dessa forma, cada indivíduo consegue se situar em suas condições atuais de vida, seu foreground, e vislumbrar, desta perspectiva, outras possibilidades de vida.

É a partir deste exercício que o indivíduo pode projetar onde quer (ou pode) chegar e definir suas intenções para a aprendizagem. 0 indivíduo observa da borda, da fronteira. Desta posição de fronteira, o significado da diferença é negociado, os contrastes entre os mundos ficam mais claros, assim como as barreiras e as dificuldades.

Segundo Boltanski (2013), aqueles sujeitos à dominação, ou ainda, numa situação de acumulação de desvantagens, desenvolvem interpretações realistas, sem ilusões, da condição que Ihes é imposta, permanecem lúcidos desta realidade, não perdem nem seu senso de justiça, nem seu desejo de conquista-las, mas essa lucidez pessoal, individual, que eventualmente toma a forma de ceticismo, raramente leva a uma ação coletiva.

Assim, enquanto alguns projetam quais universidades ou cursos conseguem chegar, outros imaginam diferentes possibilidades, como a inserção mais imediata no mercado de trabalho. A reflexão do indivíduo a partir da referida posição de fronteira pode ser considerada um esforço cognitivo pessoal, refletindo seu foreground e também as mensagens passadas veiculadas, direta ou subliminarmente, acerca de suas próprias possibilidades.

Duru-Bellat (2005) discute essa questão em termos de autoseleção, ou seja, da construção das intenções de futuro do aluno, selecionando trajetórias possíveis, dada a sua condição. Apesar de concordar no peso do contexto social, a autora questiona também a 
responsabilidade da própria escola quanto a construção destas intenções:

\begin{abstract}
Essa auto-seleção é de início escolar: quando o aluno é muito bom ou muito fraco, as intenções das famílias são respectiva e uniformemente ambiciosas ou modestas; mas as intenções dos alunos de desempenho médio caracterizam-se por grande diversidade, estruturada por idade (mesmo apresentando desempenho escolar idêntico, os aluno mais velhos manifestam intenções mais modestas) e, sobretudo, por ambiente social de origem (DURU-BELLAT, 2005, p.19).
\end{abstract}

Acrescenta-se a este quadro, o fato de que a trajetória de vida de um indivíduo é permeada de eventos que não podem ser previstos sejam eles bons ou ruins - da mesma forma que não há garantias de que o indivíduo que obteve uma boa educação consiga convertê-la em um bom emprego, uma vez que isso está condicionado às oscilações e adaptações do próprio mercado de trabalho, além de questões da ordem do perfil pessoal, psicológico ou social do indivíduo.

Outro equívoco da relação direta entre mobilidade social e escola, reside na crença de que os méritos pessoais são inteiramente determinados pelo nível de educação. Ou seja, quanto maior o tempo dedicado à educação e à formação, maior o mérito do indivíduo e, em decorrência disso, maiores os benefícios conquistados. De um lado, esta concepção ignora as diferenças entre a qualidade das escolas, de infraestrutura, de condições sociais, de situação familiar etc. Assim, ignora uma condição chave para a igualdade segundo a meritocracia: o princípio do nivelamento. De outro lado, desconsidera a educação em nível informal, obtida no convívio social e na atuação prática. Mais ainda, considera quais destas experiências são ou não consideradas como "educação" e "formação".

Esta concepção puramente meritocrática, na qual teoricamente existe um cenário de igualdade de oportunidades (a escola é gratuita e universal e qualquer pessoa pode se candidatar ao posto de trabalho e 
função que desejar), segundo Dubet (2004), se defronta com uma série de dificuldades: primeiramente, a abertura de um espaço de competição escolar objetiva não elimina as desigualdades, uma vez que as desigualdades sociais pesam muito nas desigualdades escolares. Depois, este modelo de igualdade de oportunidades meritocrático pressupõe uma oferta escolar perfeitamente igual e objetiva, não somente ignorando as citadas desigualdades sociais dos alunos, como também as legitimando. Outra dificuldade, segundo Dubet (2004), possui raízes pedagógicas, uma vez que, o princípio meritocrático pressupõe que todos os alunos estejam envolvidos na mesma competição, aprofundando as desigualdades entre os alunos que se destacam na "liderança" desta competição e aqueles que parecem incapazes de continuar competindo.

Segundo Dubet (2004), de modo a promover um sistema escolar mais justo, é importante que a escola considere as desigualdades reais entre os alunos, compensando-as a partir do princípio da discriminação positiva, ou seja, segundo Dubet (2004, p.545), evitando "a concentração excessiva de alunos idênticos, de guetos da cultura, do dinheiro e da qualidade, de um lado, e de guetos de pobreza e das dificuldades, do outro".

$\mathrm{Na}$ prática, isso se traduziu com a introdução de mecanismos compensatórios e a garantia limites mínimos, baseada no princípio da diferença proposta por Rawls (2000). Segundo Dubet (2004, p.547):

O fato é que essas garantias visam a limitar os efeitos dos sistemas meritocráticos cuja mecânica muitas vezes leva à manutenção ou mesmo acentuação das desigualdades. Essa concepção de justiça, principalmente a de Rawls, considera que a justiça de um sistema escolar pode ser medida pelo modo como trata os mais fracos e não somente pela criação de uma competição pura. Mais exatamente, ela considera que as desigualdades são aceitáveis, ou mesmo justas, quando não pioram as condições dos mais fracos. (...) Nesse caso, o sistema justo, ou menos injusto, não é o que 
reduz as desigualdades entre os melhores e os mais fracos, mas o que garante aquisições e competências vistas como elementares para os alunos menos bons e menos favorecidos.

Segundo Valle (2013), a igualdade do direito à educação se constituiu como um elemento chave para a consolidação dos projetos de democratização da sociedade. Assim, as decorrentes políticas de equidade se traduziram segundo a ideia de educação gratuita e universal, fundamentando o "dogma meritocrático de que toda expansão da escolarização é justa e eficaz" (VALLE, 2013, p.296).

No entanto, segundo Riscal (2011), apesar da ampliação do acesso à educação, o desempenho escolar dos diferentes grupos sociais é ainda bastante díspar, o que coloca em questão a hipótese de que a igualdade social pode ser atingida a partir da garantia legal de igualdade de acesso aos recursos públicos. Assim, "a concepção de equidade passou a ser concebida como resposta racional para esse dilema, porque permitiria a compensação das desigualdades por meio da alocação pontual de recursos" (RISCAL, 2011, p.249-250).

Nesse contexto, posicionar a escola como agente para a promoção da equidade significa, na realidade, reconhecer as desigualdades de oportunidades e aplicar contrapartidas compensatórias (VALLE, 2013).

\subsection{Discursos sobre matemática, escola e equidade}

No contexto geral do desenvolvimento da escola pública burguesa, o status e a importância da matemática foram reafirmados em vista de uma série de fatores. O mais direto decorre da concepção da matemática atrelada ao progresso e da herança francesa do século XVIII que preconizava uma matemática ligada à resolução de problemas da física e da engenharia (ROQUE, 2012). Desse modo, com o desenvolvimento do capitalismo industrial, a matemática assumiu 
fundamental relevância para a própria indústria (ROQUE, 2012).

No entanto, o discurso sobre a importância da matemática não deixava de se figurar num plano abstrato para a maioria da população: que matemática 0 operário das fábricas no século XIX poderia identificar ou utilizar, dada a própria lógica da linha de montagem e as suas condições de trabalho? Tal importância estava associada a uma minoria, no outro extremo da produção, no âmbito dos que produziam tecnologia. Porém, podemos supor quatro aspectos que contribuíram para que tal discurso se tornasse hegemônico.

O primeiro é a recuperação do status de superioridade a que a matemática havia sido alçada desde os ideais platônicos e aristotélicos. Para Cattanei (2005, p.34), segundo tal perspectiva,

Os entes matemáticos, que contém números da aritmética e as figuras da geometria, são as únicas realidades que existem de modo pleno, autônomo e perfeito. O saber a eles dirigido, ou seja, o saber matemático-quantitativo, constitui a única verdadeira ciência, o mais alto saber. E a ordem matemática define o que é bem e o que é belo.

Desse modo, ser conhecedor da "única verdadeira ciência" implicaria em um status superior para si próprio perante a sociedade. Segundo Keitel (2006, p.13),

Encarando a matemática como a estrutura fundamental na construção do cosmos, o número como a base do universo e enfatizando um caráter hermético da comunidade matemática, o terreno estava pronto para a alta estima da Matemática como meio de segregação de poder político e social.

Do ponto de vista de Foucault (2008, p.211), tal concepção consolida a matemática como,

A única prática discursiva que transpôs de uma só vez o limiar da positividade, o de epistemologização, o da cientificidade e o da formalização. (...) Sua positividade devia constituir uma prática discursiva já formalizada. Daí 
o fato de ser sua instauração ao mesmo tempo tão enigmática (tão pouco acessível à análise, tão fechada na forma do começo absoluto) e tão valorizada (já que vale, concomitantemente, como origem e como fundamento); daí o fato de se ter visto, no primeiro gesto do primeiro matemático, a constituição de uma idealidade que se desenrolou ao longo da história e que só foi questionada para ser repetida e purificada.

Desse modo, como as condições de individualização do sujeito que produz matemática são, de fato, muito restritas e numerosas, elas autorizam a existência de apenas um sujeito possível, já que a posição do sujeito enunciativo só pode ser ocupada pelo autor ou autores da formulação matemática, uma vez que estes estavam inscritos nas circunstâncias, métodos, falhas e inquietações da produção da formulação (FOUCAULT, 2008).

Contudo, este primeiro aspecto, conforme pode ser verificado nas citações de Cattanei (2005) e Keitel (2006), mais qualifica a matemática como um conhecimento revestido de uma aparente condição de intangibilidade, do que agrega a ela importância.

O segundo aspecto se relaciona com este primeiro no plano geral da própria organização da sociedade moderna. Segundo Löwy (2010), Condorcet formulou uma ciência da sociedade, ou uma matemática social, na qual a sociedade deveria ser estudada matematicamente: de forma numérica, precisa e rigorosa; somente assim poderia existir uma ciência dos fatos sociais verdadeiramente objetiva.

Segundo Boto (2003, p.479),

Condorcet acreditava firmemente no progresso do espírito humano, na marcha da civilização contra a ignorância. Esse movimento em direção ao esclarecimento seria, para ele, fonte de prosperidade coletiva e de aprimoramento social. Como iluminista, Condorcet via a caminhada do homem em direção à sua perfectibilidade como uma vocação do próprio gênero humano. Por isso, ele era otimista para projetar o que 
alguns qualificaram como "matemática social".

Condorcet entendia, nestes termos, a matemática e a ciência como "um antídoto contra os preconceitos, as superstições e qualquer forma de obscurantismo" (BOTO, 2003, p. 749), posicionando-as, consequentemente com um papel privilegiado na sociedade.

Estes conceitos constituíram a base do positivismo de Condorcet, que viria a sofrer uma série de modificações ao longo da história, principalmente na formulação de Augusto Comte. Considerado um discípulo indireto de Condorcet ${ }^{4}$, Comte considerava as suas propostas "demasiadamente críticas e negativas; para ele, o pensamento teria que ser inteiramente positivo, dever-se-ia acabar com toda a crítica e negatividade, isto é, com a dimensão revolucionária desse pensamento" (LÖWY, 2010, p.41).

Enquanto o positivismo utópico de Condorcet se direcionava a combater os preconceitos das classes dominantes, o positivismo de Comte refutava justamente o preconceito revolucionário de seus predecessores.

Pode-se perceber, então, que a palavra preconceito muda de função: para o positivismo em sua fase utópica, o termo preconceito serve a uma função revolucionária e crítica - é sempre o preconceito das classes dominantes, preconceito clerical, absolutista, obscurantista, fanático, intolerante, dogmático; com Comte, esse sentido muda, é o preconceito revolucionário de Condorcet, que apoiou a Revolução Francesa, ou revolucionário socialista de Saint-Simon. Deste modo, a luta contra os preconceitos muda radicalmente de função: de uma luta utópica, crítica, negativa, revolucionária, passa a ser uma luta conservadora. Comte se queixa da disposição revolucionária de Saint-Simon, com as quais ele está inteiramente em desacordo. Ele explica que seu método positivo deve se consagrar teórica e praticamente à

Segundo Löwy (2010), Comte era um discípulo indireto de Condorcet, uma vez que sua principal referência foi Saint-Simon, este sim seu discípulo direto e continuador. Saint-Simon é o primeiro a utilizar o termo "positivo" aplicado à ciência, pretendendo formular uma ciência da sociedade segundo um modelo biológico, diferente do modelo matemático de Condorcet. 
defesa da ordem real (LÖWY, 2010, p.41).

Löwy (2010) considera que à burguesia, tal ressignificação do positivismo (do campo crítico, utópico, negativo, revolucionário, para o campo conservador e legitimador da ordem estabelecida) era fundamental. Se nos séculos anteriores a burguesia se constituiu como uma classe contestadora e revolucionária, no século XIX assume a condição de classe dominante e conservadora.

Num âmbito mais amplo, porém não destacado do anterior, a partir de uma perspectiva positivista, a matemática passa a gozar do status de base para todo o conhecimento, uma imagem a ser seguida por toda e qualquer ciência (ROQUE, 2012). Segundo Popkewitz (2010, p.81), "a ciência tinha uma crença milenar no conhecimento racional, como força positiva para a ação e para o progresso trazidos à tona como parte da herança iluminista". O próprio distanciamento entre os conhecimentos científicos e os saberes comuns, decorrente da nova divisão do trabalho nas sociedades industriais (GORZ, 2005), elevou a importância das ciências e da matemática.

O terceiro se relaciona com a própria escola. Schubring (2003) apresenta um exemplo de como a escola e a matemática adquiriram relevância no cenário cotidiano. Segundo Schubring (2003), a proposta educacional de Condorcet possuiu como um elemento fundamental a produção de livros elementares (livros didáticos). Nesse sentido, em 1792, na França, a Comissão de Instrução Pública, propôs um concurso de caráter público para produção de livros didáticos de matemática. Segundo Schubring (2003, p.84), "havia um otimismo amplamente difundido de que todos os conhecimentos $e$ as qualificações necessários existiam, e de que a República tinha somente de apelar a eles para promover o bem estar social". Apesar de este projeto ter encontrado uma série de problemas de ordem política (SCHUBRING, 2003), o concurso publicizou a importância da matemática para a 
escola, assim como a participação de grandes matemáticos na organização do concurso, como d'Alembert e Lagrange, referendou a sua função atrelada à ideia de progresso e desenvolvimento.

Por fim, o quarto aspecto confere uma materialidade, ou uma efetividade prática para o discurso sobre a importância da matemática: sua utilização em exames e seleção. Segundo Roque (2012) um marco nesse sentido foi a utilização da matemática como um dos principais elementos para a admissão na École Polytechnique no período pósRevolução Francesa, consolidando dessa forma, o papel da matemática também no jogo meritocrático. Nesse sentido, segundo Silva (2013, p.87):

No universo da educação, os exames, as avaliações, as provas, os testes etc. são instrumentos que, independentemente da maneira como são abordados e operacionalizados, cumprem, sobretudo, o propósito de aferir méritos.

Amparado nestes aspectos, constitui-se um discurso hegemônico sobre o ensino de matemática, que se manterá relativamente estável nos anos seguintes. O discurso da importância da matemática para o progresso da sociedade e o desenvolvimento tecnológico ultrapassa o cenário das sociedades industriais, se reinterpretam constantemente, seja no contexto da corrida tecnológica entre EUA e URSS no período pós-guerra, seja no contexto da globalização, com o desenvolvimento da informatização e da sociedade em rede. Da mesma forma que na escola do século XIX, a preponderância da matemática nos currículos escolares e seu destacado uso como critério de seleção, reafirmam sua importância.

Inserido no discurso da escola atrelada à formação para a cidadania, o ensino de matemática contribuiria para a consolidação de relações sociais democráticas tanto na esfera escolar, quanto fora. (SKOVSMOSE E VALERO, 2002). No entanto, a própria noção de 
formação do cidadão, implica a adequação do indivíduo a um conjunto de normas e regras sociais. Uma vez que o discurso meritocrático não somente permeia tais normas e regras, como também incorpora a matemática como um elemento para aferição de mérito, posiciona a matemática com uma potencial função excludente.

Dessa forma, Skovsmose e Valero (2002, p.391) ponderam que,

Há uma contradição entre o estabelecimento de uma educação matemática em termos de acesso democrático e, ao mesmo tempo, permitindo que a educação desempenhe funções de diferenciação na sociedade através, por exemplo, com a classificação os alunos de uma forma que influencie significativamente suas possibilidades de carreira futura.

Nesse contexto, tanto a partir do discurso sobre a importância da matemática, quanto de sua função social potencialmente excludente, estabelece-se um discurso que demanda pelo acesso democrático ${ }^{5}$ à matemática em termos globais e que aponta o aprendizado da matemática como um direito humano: "a noção de que as crianças devem ter acesso democrático às poderosas ideias matemáticas é um direito humano, e é importante para o futuro da nossa sociedade" (MALLOY, 2002, p.18).

No entanto, Gutiérrez (2013a, p.47) avalia que a noção de poder na educação matemática se relaciona a dois grandes construtos principais: "o poder da matemática e o poder associado com ser bem sucedido em matemática". O primeiro assume uma perspectiva mais utilitarista da matemática, no sentido de posicioná-la de forma

${ }^{5}$ Segundo Gutstein (2004) e Lerman (2000), o conceito de equidade na educação matemática assumiu diversas interpretações ao longo dos anos, desde a ênfase quanto ao acesso democrático a recursos e condições educacionais na década de 1980 , até as discussões sobre numeramento no fim dos anos 1990 e 2000 . 
privilegiada para arbitrar a verdade a partir de sua razão e formalidade intrínsecas, tal qual defendiam Platão e Aristóteles. "É como se a matemática trouxesse algo separado dos humanos que pode ser transmitido aos indivíduos, proporcionando-Ihes uma visão a mais do mundo" (GUTIÉRREZ, 2013a, p.47).

O segundo construto apontado por Gutiérrez (2013) corresponde ao status conferido àqueles que são considerados bem sucedidos em aprender matemática. Este construto se relaciona intimamente com o primeiro na medida em que, uma vez que a matemática é entendida um "árbitro da verdade", o indivíduo que a domina agrega para si a mesma condição.

Por fim, segundo Valero (2002), afirmar que a matemática é "poderosa" implica que ela em si exerce poder, associando-a consequentemente a uma agência que ela própria não possui, conduzindo desta forma a uma nova concepção platônica. Dito de outra forma, não se deve personificar a matemática, atribuindo-a traços de uma vida própria, de uma autonomia quase humana. A matemática é uma criação humana e, como tal, está sujeita às formas culturais e sociais nas quais é produzida, assim como às inúmeras disputas e interesses, explícitos e implícitos, que permeiam a sua produção. A relevância e o nível de poder da matemática dependem de como a sociedade se constitui e a posiciona segundo um ou outro determinado papel.

Nesse sentido, Gutiérrez (2013a, p. 47) propõe que,

Em vez de perpetuar a ideia de que a matemática tem um poder intrínseco, podemos querer que os cidadãos desenvolvam a habilidade de discernir, por si mesmos, que tipos de perguntas podem ou não ser respondidas usando a matemática. Ao pensar criticamente sobre os benefícios e as desvantagens de formatar realidades com a matemática, podemos ser mais deliberados em como e 
quando usar/criar matemática em nossas vidas cotidianas.

Segundo esta concepção, retira-se o "peso" que paira sobre a necessidade, ou obrigatoriedade, de aprender matemática, colocando-a como mais um elemento de todo arcabouço de conhecimentos de uma determinada cultura e sociedade. Desse modo, para lidar com uma dada situação proposta no convívio social - em face de suas próprias experiências e interesses - o indivíduo analisaria seus repertórios pessoais em busca de abordagens apropriadas para lidar com esta situação (GUTIÉRREZ, ROGOFF, 2003). Em outras palavras, aprender matemática não deveria ser entendido como uma urgência dado o poder que a mesma possui e que o seu aprendizado poderia conferir, mas como um direito que todo cidadão possui de conhecer sua própria história e cultura, e mobiliza-los da maneira que melhor julgar. 


\section{ANÁLISE DOCUMENTAL: DISCURSOS SOBRE EQUIDADE, EDUCAÇÃO E MATEMÁTICAS}

O objetivo deste capítulo não é identificar, documento por documento, como os discursos sobre equidade, educação e matemática se apresentam e articulam entre si, mas entende-los num quadro mais amplo. A justificativa é que entendemos que tais discursos não foram "criados" ou "inventados" especificamente por algum dos documentos citados. Como discutido nos capítulos anteriores, estes discursos possuem um percurso histórico longo, sendo inventados e reinventados por diferentes grupos, em diferentes contextos.

Ao longo deste texto, o termo discurso foi referido e mobilizado em diversas ocasiões sem, no entanto, uma devida conceptualização. Desse modo, a seguir, delinearemos nossa concepção de discurso e apresentaremos, à luz desta concepção, a análise crítica do discurso como abordagem metodológica.

Concebemos o discurso como um conjunto de enunciados e narrativas, seja na forma falada ou escrita, que representam as ideias sobre o mundo, os significados dados às ações na sociedade, as formas de expressá-las e, também, as formas sobre como o mundo é envolvido por tais ideias (FAIRCLOUGH, 2001).

Segundo Foucault (2014), há certo desnivelamento entre os discursos, podendo ser observados dois tipos principais de discursos, que apesar não terem limites sempre perceptíveis, estabelecem papéis "solidários" entre si: existem aqueles próprios das trocas cotidianas, que se extinguem pouco após $o$ ato que os pronunciou, mas também aqueles que,

estão na origem de certo número de atos novos de fala que os retomam, os transformam ou falam deles, ou seja, 
os discursos que, indefinidamente, para além de sua formulação, são ditos, permanecem ditos e estão ainda por dizer (FOUCAULT, 2014, p.21).

Segundo Gutiérrez (2013, p. 43):

Os discursos significam muito mais do que a fala e as palavras. Os discursos incluem instituições, ações, palavras e formas de interação e operação tomadas por garantidas. Então, de certa forma, os discursos podem ser pensados mais como paradigmas nos quais operamos. Os discursos refletem um ponto particular na história, incluindo relações específicas entre pessoas, conhecimento e agência; eles vêm para definir o que pensamos como "normal". (..) A importância de compreender os discursos dessa maneira é que eles produzem "verdades".

Isso se justifica na perspectiva de Foucault (2014, pp.8-9), segundo a qual a produção do discurso passa por procedimentos de controle, seleção, organização e redistribuição, de modo a "dominar seu acontecimento aleatório, esquivar sua pesada e temível materialidade", ou seja, conforme Gutiérrez (2013, p.43), "eles [os discursos] não refletem apenas uma ordem natural do mundo; em vez disso eles estruturam o mundo.

Desse modo, o discurso se encontra implicado num jogo de tensões, disputas e sujeito a relações de poder, se produzindo e renovando segundo uma relação de controle, seleção, organização e redistribuição (FOUCAULT, 2014 E 2008; FAIRCLOUGH, 2001; VALERO, 2002; PAIS, STENTOFT, VALERO, 2010). Assim, o discurso pode ser concebido como uma prática social, não como uma atividade puramente individual ou um reflexo de variáveis situacionais (FAIRCLOUGH, 2001).

Retomando as questões propostas anteriormente à luz da concepção de discurso delineada, a investigação sobre supostos interesses e possíveis beneficiários dos discursos sobre igualdade e 
equidade deve ser considerada de forma secundária, uma vez que o entendimento sobre como tais discursos são produzidos, quais são as relações de poder envolvidas e como operam suas estratégias de controle precisam ser assumidos como o eixo central. Isso porque a sua produção se dá com base em uma multiplicidade de enunciados e discursos, a partir dos quais, segundo Foucault (2008, p.70), são estabelecidas "regularidades e coações discursivas" que ocasionam a sua heterogeneidade.

Em outras palavras, não entendemos que a origem dos conceitos de igualdade e equidade guarde em si concepções ocultas, representativas de um único grupo ou sujeito cognoscente. Tais conceitos são fruto de um jogo discursivo inserido numa arena na qual diversos grupos disputam e negociam seus conceitos, cada qual segundo sua "lente" de valores e entendimento de mundo.

Os discursos sobre a função social da educação e do ensino de matemática, assim como os paradoxos deles depreendidos, determinam o contexto ao mesmo tempo em que são alimentados e reiterados por ele. Uma vez que o discurso é entendido, segundo Fairclogh (2001), como uma forma de ação das pessoas sobre o mundo e sobre outras pessoas, ele assume uma relação dialética com a estrutura social, sendo esta tanto uma condição quanto um efeito do discurso. Em outros termos, o discurso não deve ser considerado nem como um reflexo fiel da sociedade, nem como a fonte do social (FAIRCLOUGH, 2001).

A partir dessa relação, o discurso se configura como uma prática política e ideológica, constituindo, transformando e naturalizando os diversos significados do mundo (FAIRCLOUGH, 2001).

De modo a analisar os discursos presentes nos documentos 
elencados, procuraremos definir procedimentos metodológicos que permitam uma aproximação adequada ao nosso objeto de estudo. Nesse sentido, como já anunciado anteriormente, adotamos a análise do discurso como abordagem metodológica. Esta, por sua vez se encontra inserida no campo da pesquisa qualitativa, entendida aqui como orientação metodológica geral.

Segundo Ollaik e Ziller (2012, p.232),

A pesquisa qualitativa busca descrever e compreender um fenômeno, e não explicá-lo ou fazer previsões. Tais descrição e compreensão estão restritas a um contexto específico a partir do qual se chega a um tipo de conhecimento distinto do que é alcançável por procedimentos estatísticos ou por outras formas de quantificação. Em vez de explicar, busca-se descrever. Em vez de prever, busca-se compreender. Em vez de generalizar, busca-se a possibilidade de extrapolação para situações com contextos similares.

Para Bicudo (2006, p.106), "o significado atribuído a essa concepção de pesquisa também engloba noções a respeito de percepções de diferenças e semelhanças de aspectos comparáveis de experiências". Dessa forma, a pesquisa qualitativa não é isenta dos valores ou das condições sócio-políticas vigentes. Sharma (2013) salienta ainda que a pesquisa qualitativa possibilita uma maior profundidade de detalhes ao trazer para a discussão citações diretas e descrições do contexto. Isso implica também que a pesquisa precisa ser construída de baixo para cima, com idas e vindas entre os temas analisados e o banco de dados, organizando-os em unidades cada vez mais abstratas de informação, até que se obtenha um conjunto relativamente abrangente de temas.

Para Kripka, Scheller e Bonotto (2015, p.244), uma característica dos estudos qualitativos é a busca pela compreensão dos fenômenos 
em seu ambiente natural, ou seja, onde ocorrem e do qual fazem parte. Nesse sentido, sinalizam ao fato de que neste tipo de estudo, o pesquisador "mergulha" no campo de estudo, buscando "captar o fenômeno a partir das perspectivas contidas nos documentos". Uma vez que nesta tese o objeto de estudo é primordialmente o discurso, isso significa realizar, segundo Foucault (2008), a análise no jogo de sua instância, no momento em que se tornam manifestos ou constatáveis. A partir da hipótese assumida nesta tese, de que nos documentos dos quais esta tese se propõe a analisar estão presentes os discursos hegemônicos de um dado período, consideramos que a análise destes documentos possibilitará, dessa forma, cumprir os aspectos levantados por Kripka, Scheller e Bonotto (2015) e Foucault (2008).

$\mathrm{Na}$ realização de um estudo qualitativo, podem ser utilizados procedimentos ou abordagens metodológicas diversas, como o uso de questionários, entrevistas, observação de práticas ou fenômenos etc. Dentre suas possíveis abordagens, adotaremos a pesquisa documental, como já sugerido até este ponto.

Segundo Pimentel (2001), os estudos baseados em documentos como material primordial, extraem deles toda a análise, organizando-os e interpretando-os segundo os objetivos propostos. Uma vez decididos os tipos de documentos que se pretende utilizar (em nosso caso, legislação e documentos oficiais) é necessário construir um corpus, uma amostra representativa destes documentos (já citados no recorte estipulado no tópico anterior).

A aproximação deste corpus se baseará na análise do discurso, entendida, segundo Caregnato e Mutti (2006, p.680), não como uma metodologia, mas como "uma disciplina de interpretação fundada pela intersecção de epistemologias distintas". Desse modo,

O processo de análise discursiva tem a pretensão de 
interrogar os sentidos estabelecidos em diversas formas de produção, que podem ser verbais e não verbais, bastando que sua materialidade produza sentidos para interpretação (CAREGNATO, MUTTI, 2006, p.680)

Mais especificamente, adotaremos a concepção da análise crítica do discurso, proposta em Fairclough (2012). A partir desta concepção, existe uma relação dialética entre a semiose (entendida como uma multiplicidade de formas de construção de sentidos) e as atividades produtivas, meios de produção, relações sociais, identidades sociais, valores culturais e consciência (FAIRCLOUGH, 2012).

A análise crítica do discurso corresponde, dessa forma,

à análise das relações dialéticas entre semioses (...) e outros elementos das práticas sociais. Essa disciplina preocupa-se particularmente com as mudanças radicais na vida social contemporânea, no papel que a semiose tem dentro dos processos de mudança e nas relações entre semiose e outros elementos sociais dentro da rede de práticas (FAIRCLOUGH, 2012, p.319).

Segundo Fairclough (2012), entendida como parte da atividade social, a semiose constitui os gêneros discursivos que, por sua vez, podem ser entendidos como maneiras diversas de agir e de produzir a vida social. É na representação e autorrepresentação das práticas sociais que os discursos se constituem. As funções sociais atribuídas à matemática, por exemplo, estão representadas nas práticas sociais em certa instância, mas não somente - a partir do currículo, sendo que as posições de diferentes atores sobre estas práticas corresponderiam ao que estamos denominando como discurso.

Outro aspecto relevante para a análise crítica do discurso é considerar as ordens do discurso como o aspecto semiótico segundo o qual as diversas ordens socais se relacionam e constituem uma ordem social (FAIRCLOUGH, 2012). 
É a maneira de os diversos gêneros e discursos estarem inter-relacionados entre si. Uma ordem de discurso é uma estruturação social da diferença semiótica, uma ordenação social particular das relações entre os vários modos de construir sentido, isto é, os diversos discursos e gêneros. (...) Um aspecto dessa ordenação é a dominância: algumas maneiras de construir sentido são dominantes ou estão em voga para certas ordens de discurso; outras são marginais, subversivas, alternativas. (FAIRCLOUGH, 2012, p.319).

A partir destes elementos, consideraremos a estrutura analítica proposta por Fairclough (2012) para o estudo sobre o discurso. Em primeiro lugar, a ênfase da análise deve incidir sobre um problema que possua um aspecto semiótico. Nesse sentido, os discursos sobre equidade presentes nos documentos oficiais e na legislação, assim com os seus desdobramentos e inter-relações com o ensino de matemática, possuem tal condição, uma vez que os significados para a equidade são negociados em várias arenas, desde uma conjuntura internacional no âmbito dos governos e das organizações multilaterais, até a sala de aula e o cotidiano dos indivíduos. Da mesma forma, tais discursos quando oficializados nestes documentos, por um lado ganham legitimidade e autoridade, reforçando sua hegemonia, por outro, possibilitam uma crítica mais focada e sistematizada, dada sua própria materialização em forma de documentos escritos.

Em segundo lugar, Fairclogh (2012) propõe que sejam identificados possíveis obstáculos para a resolução deste problema, considerando a rede de práticas na qual se inserem, as relações com outros elementos dentro das práticas em questão e, por fim, o próprio discurso.

Atrelado a isso, mas segundo um ponto de vista analítico, é necessário que se contemple o texto em si, ou seja, segundo Fairclough (2001): que palavras tem significado cultural geral ou mais local? Qual o significado potencial de determinada palavra? Existem 
padrões no texto que permitem avaliar o significado relativo das características da modalidade para as relações sociais no discurso e o controle das representações da realidade? Quais relações e as estruturas sociais hegemônicas que constituem a matriz dessa instância particular da prática social e discursiva? Que efeitos ela traz, em termos de sua reprodução ou transformação?

Por fim, Fairclough (2012) propõe que à luz da análise realizada, sejam identificadas maneiras possíveis de superação dos obstáculos e problemas, assim como refletir criticamente sobre o próprio processo de análise destes obstáculos e problemas.

Nesse sentido, segundo Fairclough (2012), a ordem social pode ser concebida como a forma como diversas práticas sociais se interrelacionam de uma maneira particular. No caso dos documentos aqui contemplados, a ordem social segundo a qual sua produção e circulação estão inseridas é a da globalização do fim dos anos 1980 até os anos 2000, quando o mundo constatava os resultados e efeitos das políticas neoliberais, ampliava a importância e o alcance das organizações multilaterais e desenhava uma nova agenda política internacional para a educação.

Segundo Fairclough (2012, p.310),

O aspecto semiótico de uma ordem social é o que podemos chamar de ordem de discurso. É a maneira de os gêneros e discursos estarem inter-relacionados entre si. Uma ordem de discurso é uma estruturação social da diferença semiótica, uma ordenação social particular das relações entre os vários modos de construir sentido, isto é, os diversos discursos e gêneros. Um aspecto dessa ordenação é a dominância: algumas maneiras de construir sentido são dominantes ou estão em voga para certas ordens de discurso; outras são marginais, subversivas, alternativas.

Assim, de modo a compreender a ordem e a inter-relação dos 
discursos sobre equidade, educação e matemática, organizaremos a análise segundo três grandes temas: educação para todos (contemplando a relação entre os discursos sobre equidade e educação, assim como seus apontamentos para a agenda política internacional para a educação); em seguida, a educação para todos em vista de suas implicações na legislação educacional brasileira; e por fim, a forma como o ensino de matemática dialoga com estes discursos. Primeiramente, situaremos o contexto ou ordem social de cada tema e, de modo a construir uma narrativa analítica, mobilizaremos diferentes documentos do corpus que se relacionam com o tema e a ordem social na qual estão inseridos.

Por fim, a seguir, apresentaremos alguns elementos e concepções que irão compor um quadro analítico geral para orientar o estudo do corpus.

\section{a. Intertextualidade}

A intertextualidade representa a superposição de um texto por outro, ou seja, é a utilização de um texto dentro de outro texto, e assim por diante. Segundo Fairclough $(2001)^{6}$, a intertextualidade representa a inserção da história no texto, ao absorver os textos do passado, e do texto na história, ao retrabalhar os textos do passado e, dessa forma, contribuir para a sua mudança no presente.

No entanto, segundo alerta Fairclough (2001, p.137),

A intertextualidade é a fonte de muita da ambivalência dos textos. Se a superfície de um texto pode ser

6 Em referência a KRISTEVA, J. Word, dialogue and novel. In: Moi, T. (ed.) The Krisieva reader. Oxford: Basil Blackwell, 1986. 
multiplamente determinada pelos vários outros textos que entram em sua composição, então os elementos dessa superfície textual não podem ser claramente colocados em relação à rede intertextual do texto, e seu sentido pode ser ambivalente; diferentes sentidos podem coexistir, e pode não ser possível determinar o sentido.

A intertextualidade pode ser observada tanto horizontalmente, quando os textos se inter-relacionam em cadeia, quanto verticalmente, quando esta relação se estabelece a partir uma ligação histórica ou com base num determinado contexto (FAIRCLOUGH, 2001), como o caso da paráfrase.

Fairclough (2001) aponta, desse modo, que a intertextualidade pode ser manifesta, ou seja, outros textos estão "manifestamente" presentes, indicados por aspas ou pela evocação do autor. É possível, entretanto, que a própria ordem do discurso ou determinadas convenções discursivas estejam claras, sem que a elas se façam referências diretas ou que sejam nominalmente evocadas. Estas, Fairclough (2001) denomina por intertextualidade constitutiva ou interdiscursividade.

\section{b. Modalidade}

Em um enunciado do tipo "aprender matemática é necessário para o exercício da cidadania", fica explícita a ideia veiculada pela frase e associação entre "aprender matemática" e "exercício da cidadania". O mesmo vale para a formulação negativa deste mesmo enunciado, "aprender matemática não é necessário para o exercício da cidadania". O uso dos termos "é" e "não é", segundo Fairclough (2001), comprometem categoricamente o enunciador com o sentido da frase, ou seja, o enunciador deve sempre declarar seu grau de afinidade ${ }^{7}$ com a

7 Em referência a HODGE, R.; KRESS, G. Social semiotics. Cambridge: Polity Press; Ithaca: Cornell University Press, 1988. 
proposição enunciada.

No entanto, é possível obter diferentes graus de comprometimento ao utilizar advérbios modais como "possivelmente", "provavelmente", "certamente" etc., ou variações como "de certo modo" e "pode ser". Em nosso exemplo, são formulações possíveis: "aprender matemática é definitivamente necessário para o exercício da cidadania", ou "aprender matemática possivelmente necessário para o exercício da cidadania"; assim, cada qual apresenta um nível de comprometimento distinto com a relação "aprender matemática" e "exercício da cidadania". Todo enunciado desse tipo é então considerado modalizado.

Segundo Fairclough (2001), o grau de afinidade do enunciador pode ser dado de forma subjetiva ("suponho que aprender matemática é necessário para o exercício da cidadania") ou de forma objetiva ("aprender matemática pode ser necessário para o exercício da cidadania"). No caso da modalidade subjetiva, fica claro qual o grau de comprometimento do enunciador (" $[e u]$ penso que"). Já no caso da modalidade objetiva, esse comprometimento não fica claro ("pode ser" mascara "quem" considera "aprender matemática" como necessário ou não para o "exercício da cidadania".

$\mathrm{Na}$ interpretação ou análise da modalidade em um enunciado, conforme sinaliza Fairclough (2001), é importante considerar que quando um enunciador expressa alta afinidade em relação a uma proposição, isso não necessariamente indica seu alto comprometimento com tal proposição, mas sim uma demonstração de solidariedade para com a ideia expressa no enunciado. Dessa forma, o enunciado "aprender matemática é definitivamente necessário para o exercício da cidadania", por uma lado pode indicar convicção, por outro, pode se configurar como uma estratégia, por exemplo, de convencimento ou 
coerção. Já um enunciado em que está representada uma baixa afinidade com determinada proposição como, "aprender matemática pode ser necessário para o exercício da cidadania", segundo Fairclough (2001), implica em duas situações possível. A primeira é que o enunciador não possui conhecimento suficiente ou conviç̧ão sobre a proposição. A segunda é que o enunciador, a despeito de ter conhecimento e conviç̧ão, não se sente autorizado a utilizar uma modalização mais categórica. Ou seja, existem relações de poder que desautorizam o enunciador. Segundo Fairclough (2001, p.201), "a modalidade é, então, um ponto de intersecção no discurso, entre a significação da realidade e a representação das relações sociais".

\section{c. Transitividade}

Segundo Fairclough (2001), a transitividade lida com os processos e os elementos envolvidos na formulação de um enunciado. Os processos podem ser relacionais, quando o verbo indica uma relação ("ser", "estar" etc.); de ação, quando o verbo aponta para uma ação em direção a um objetivo; de evento, estruturado da mesma forma que o processo de ação, mas sem um objetivo explícito; e mentais, expressos por verbos como "saber", "pensar" (cognitivos), "ouvir", "ver", "sentir" (perceptivos), "gostar" e "temer" (afetivos).

Tomando o seguinte enunciado como exemplo, "os estudantes estão mobilizados para discutir as regras da escola", estão presentes alguns destes processos: "estão" implica uma relação e "discutir", uma ação.

Compreender os tipos de processo nos leva identificar quem são os sujeitos da ação nos enunciados. Quando a análise se expande de uma única oração para um texto maior, isso pode revelar como determinadas vozes assumem a preponderância enquanto outras 
tendem a ser minimizadas ou mesmo silenciadas. No exemplo acima, os sujeitos da ação são os "estudantes". No entanto, se a oração for reformulada como "a discussão das regras da escola mobilizou os estudantes", o foco do enunciado não está mais "nos estudantes", mas na "discussão" ou nas "regras da escola".

Segundo Fairclough (2001), outra característica da transitividade é a nominalização dos processos, ou seja, a conversão de processos em nomes, implicando o efeito de por o processo em segundo plano e tornando implícitos os sujeitos da ação. Segundo Fairclough (2001, p.227), "a nominalização transforma processos e atividades em estados e objetos, e ações concretas em abstratas". Em nosso exemplo, "regras da escola" é um exemplo de nominalização, já que representa todo um conjunto de regras e não explicita quais destas regras são efetivamente o objeto da "discussão" ou que acarretaram na "mobilização dos estudantes".

Segundo Fairclough (2001, p.223),

Uma motivação social para analisar a transitividade é tentar formular que fatores sociais, culturais, ideológicos, políticos ou teóricos determinam como um processo é significado num tipo particular de discurso (e em diferentes discursos), ou num texto particular.

No exemplo, a "mobilização dos estudantes" poderia ser tratada como um processo de evento, algo que ocorre, sem a necessidade de justificar as motivações dos sujeitos envolvidos, a trajetória percorrida pelos sujeitos até que a "mobilização" fosse efetivada, ou se "estudantes" se refere a todo o grupo de alunos da escola ou somente uma parte deles. Nesse sentido, Fairclough (2001) pondera que a escolha do tipo de processo sugere significações políticas ou ideológicas. 
Segundo Fairclough (2001), o uso da voz passiva, associado à nominalização, é outro aspecto que contribui para o apagamento do sujeito da ação.

\begin{abstract}
A voz passiva muda o objeto para a posição inicial de 'tema', o que usualmente significa apresenta-lo como informação já 'dada' ou conhecida; a passiva também muda o agente, se não o omite, para a posição proeminente no final da oração onde em geral encontramos a informação nova (FAIRCLOUGH, 2001, p.226).
\end{abstract}

Nesse sentido, a análise do tema, segundo Fairclough (2001, p.228), "pode jogar luz sobre os pressupostos de senso comum a respeito da ordem social e das estratégias retóricas".

\title{
d. Legitimação
}

Todo enunciado está sujeito a uma dada ordem do discurso, à regras que autorizam ou referendam sua proposição. Entendemos por legitimação, o processo de "autorização" deste enunciado. Segundo Lyotard (2013), a legitimação pode ser entendida, por exemplo, como o processo segundo o qual um legislador é autorizado a promulgar determinada lei como norma, ou o processo pelo qual um discurso científico deve passar para que seja levado em consideração pela comunidade científica.

Leeuwen (2008) destaca que a autorização de um enunciado pode ocorrer de diversas formas: apelar à autoridade pessoal ("eu, como pesquisador, considero que..."), à autoridade impessoal ("é política desta empresa..."), evocar especialistas ("segundo Foucault..."), recorrer a modelos ideais ("segundo o sábio..."), ressaltar a tradição ("assim como desenvolvido por várias gerações..."), ou se utilizar da conformidade ("a maioria dos educadores..."). 
Segundo Leeuwen (2008) a legitimação também pode decorrer de uma avaliação moral, baseada em valores. Nesse sentido, dispensando a imposição de qualquer tipo de autoridade ou justificativa. A legitimação ocorre por meio de palavras chave como "bom", "mal", "útil", "natural" etc. No entanto, estas palavras apenas insinuam os discursos, sem explicitá-los, como por exemplo, em "as políticas de melhoria das condições de vida..." ou "é saudável para a sociedade que...".

Desse modo, para Leeuwen (2008, p.110),

Tais adjetivos são, então, a ponta de um iceberg submerso de valores morais. Eles desencadeiam um conceito moral, mas são destacados do sistema de interpretação do qual derivam, pelo menos em um nível consciente. Transmutam os discursos morais no tipo de "motivos generalizados" que, como disse Habermas $(1976, \text { p.36) })^{8}$, são agora "amplamente usados para garantir a lealdade em massa". Como resultado, não é possível encontrar um método linguístico para identificar avaliações morais desse tipo.

Nesse sentido, a identificação desta forma de legitimação sempre está atrelada ao nosso conhecimento cultural sobre o senso comum Leeuwen (2008).

Outras estratégias de avaliação moral, descritas por Leeuwen (2008), se referem ao uso tanto de abstração, quanto de analogias. No primeiro caso, o enunciador se refere à determinadas práticas de maneira abstrata, de tal forma que as conecte a discursos de valores morais. É o caso, por exemplo, de um aluno que utiliza recursos numéricos ou quantitativos para modelar um dado problema cotidiano. Em relação a esta prática, podemos enunciar que "o aluno, empoderado pelo uso da matemática, resolveu o problema". Da mesma

8 HABERMAS, J. Legitimation Crisis. London: Heinemann, 1976. 
forma, "crianças que tomam decisões sozinhas" pode ser enunciado em termos de "autonomia", ou "alunos trabalhando em grupo" em termos de "sociabilização", "solidarização", "cooperativismo" etc.

O enunciador faz uso de analogias, por sua vez, quando justifica determinada posição a partir da comparação com outras práticas associadas a valores positivos ou negativos, dependendo do caso. Leeuwen (2008) recupera o livro "Sociedade sem escolas", de Ivan Illich, como exemplo deste tipo de produção de julgamento moral: no livro, o autor "importa termos do exército, da prisão, etc., para se referir às ações de professores e fala de "perfurar alunos", "encarcerar alunos", e assim por diante" (LEEUWEN, 2008, p.112).

Por fim, a última estratégia de legitimação descrita por Leeuwen (2008) é a racionalização. Nesse sentido, é a racionalidade que legitima os enunciados por meio da referência a seus objetivos, usos e efeitos ou, por referência a uma ordem natural das coisas. Assim, no primeiro caso, denominado por Leeuwen (2008) como racionalização instrumental, os enunciados geralmente contemplam três elementos nucleares: uma atividade, um propósito e um elemento de ligação entre atividade e propósito (LEEUWEN, 2008). É o caso, por exemplo, de um enunciado como "o professor dirigiu-se para o aluno a fim de responder sua dúvida". A atividade corresponde a "o professor dirigiu-se para o aluno", o propósito é "responder sua dúvida" e o elemento de ligação é "afim de". Contudo, é interessante notar que se forem inseridos adjetivos modais no enunciado, este passa a agregar também uma avaliação moral: "o professor dirigiu-se severamente para o aluno a fim de responder sua dúvida".

Da mesma forma, podemos expandir tal enunciado para a seguinte formulação: "o professor dirigiu-se severamente para o aluno a fim de responder sua dúvida, já que era fundamental que todos 
compreendessem aquele conteúdo". Assim, é adicionada outra tríade de atividade-ligação-propósito que se relaciona com as demais e amplia o grau de legitimação do enunciado, uma vez que novas justificativas e, neste caso, julgamentos morais incorporam $o$ enunciado.

A legitimação de um dado enunciado pode também ser fundamentada não por suas justificativas, seus valores morais ou seus propósitos, mas por algum tipo de verdade fundado na "maneira como as coisas são" (LEEUWEN, 2008, p.116). Este tipo de racionalização teórica, segundo a denominação de Leeuwen (2008), se baseia na naturalização de práticas ou atividades. Para tanto, tal naturalização pode decorrer a partir de uma definição, baseada, por sua vez, em uma atividade moralizada (LEEUWEN, 2008). É o caso, por exemplo, do enunciado: "o desenvolvimento cognitivo da criança é um dos princípios desta escola". Porém, a naturalização também pode se apresentar como uma explicação (LEEUWEN, 2008), ou seja, não é a atividade o alvo da naturalização, mas porque ela deve ser realizada: "a criança aprende matemática para desenvolver-se cognitivamente".

Por fim, Leeuwen (2008) propõe que a previsão como uma forma de naturalização, ou seja, a partir da experiência ou da perícia do enunciador em determinada atividade, é possível prever efeitos ou resultados da prática: "após a fase de adaptação na escola, as crianças se adequam à rotina".

A produção dos documentos que compõem o corpus da pesquisa, dessa maneira, incorporou partes destes discursos, por um lado reinterpretando-os e por outro os reiterando; tais documentos não são nem a origem dos discursos, nem simplesmente um papel branco sobre o qual o discurso hegemônico é oficializado. 
A seguir, será realizada a análise do corpus a luz da concepção de discurso adotada e possuindo como referência a análise critica do discurso.

\subsection{Educação Para Todos}

Os discursos sobre igualdade e equidade se transformaram e se revisaram ao longo da história e dos contextos político, econômico social e cultural; seja quando inseridos no modelo de Estado-educador (CHARLOT, 2013a) e nas políticas de bem estar social do período pós Segunda Guerra Mundial, seja como parte do próprio discurso das políticas neoliberais no contexto da crise estrutural do capitalismo ao final dos anos 1970, a associação destes discursos com a educação assumiu diferentes perspectivas: universalização do ensino, igualdade de acesso à educação, inclusão etc.

No caso da "educação para todos", apesar de popularizada como política internacional a partir dos anos 1990, sua presença nos discursos internacionais sobre educação se confunde com a própria história da UNESCO. Nesse sentido, a Declaração de Jomtien, assinada na Conferência Mundial Sobre Educação Para Todos, realizada sob a égide da UNESCO, do UNICEF, do Programa das Nações Unidas para o Desenvolvimento (PNUD) e do Banco Mundial, demarcou, por um lado, o início de uma agenda política internacional segundo o lema educação para todos, por outro, representou o ápice de uma série de discussões realizadas pela própria UNESCO desde os primeiros anos de sua fundação, em 1945, ao fim da Segunda Guerra Mundial.

O texto da Constituição da UNESCO, de 1945, reflete a perplexidade do mundo com os últimos anos: 
Os Governos dos Estados Partes desta Constituição, em nome de seus povos, declaram: que a grande e terrível guerra que agora terminou foi uma guerra tornada possível pela negação dos princípios democráticos da dignidade, igualdade e respeito mútuo dos homens, e pela propagação, em seu lugar, através da ignorância e do preconceito, da doutrina da desigualdade de homens e raças; que a ampla difusão da cultura e a educação da humanidade para a justiça, a liberdade e a paz são indispensáveis à dignidade do homem e constituem um dever sagrado que todas as nações devem cumprir em espírito de mútua assistência e preocupação (UNESCO, 2002, p.5)

A educação é posicionada pela UNESCO como um instrumento de redenção da humanidade em face à tragédia da Segunda Guerra Mundial, devendo, dessa forma, ser alçada ao mais alto grau de importância, sugerindo-se, metaforicamente, uma deidade, por meio da palavra "sagrado". É neste contexto que o lema educação para todos é proposto na Constituição:

Por estas razões, os Estados Parte nesta Constituição, acreditando em oportunidades plenas e iguais de educação para todos, na busca irrestrita da verdade objetiva, e na livre troca de ideias e conhecimentos, estão acordados e determinados a desenvolver e expandir os meios de comunicação entre os seus povos, empregando esses meios para os propósitos do entendimento mútuo, além de um mais verdadeiro e mais perfeito conhecimento das vidas uns dos outros (UNESCO, 2002, p.5, grifo nosso).

Da forma como é proposta no texto, as funções e objetivos da educação permanecem de certo modo obscurecidos pela própria construção retórica do texto da Constituição da UNESCO, relacionando-se tanto com a produção de conhecimento quanto com a sua circulação cotidiana e um propósito que sinaliza para um contexto de solidarização e tolerância ("entendimento mútuo", "vidas uns dos outros"). 
O trecho, no entanto, oferece referências quanto ao entendimento da UNESCO sobre suas concepções de "educação para todos", amparada no discurso da igualdade de oportunidades ("oportunidades plenas e iguais") e, consequentemente, segundo uma perspectiva meritocrática. A concepção de diferença também é referenciada ("povos", "vidas uns dos outros") sobre o véu da tolerância, como sinalizado acima.

Em novembro de 1949, foi realizada em Paris a $4^{\text {a }}$ Seção da Conferência Geral da UNESCO na qual foram traçados os principais objetivos e linhas de ação da organização para os anos seguintes, particularmente para a educação.

Assim, foram propostos seminários e reuniões regionais de modo tanto a preparar a Conferência Geral que ocorreria no ano seguinte, quanto de questionar os países membros sobre propostas e avanços em relação às proposições da Constituição sobre o oferecimento de "educação para todos" Tais seminários e reuniões abarcaram uma variedade de temas e formas de aproximação a eles, desde propostas de revisão dos livros didáticos de história e geografia, a padronização das terminologias científicas, estratégias para popularização a ciência, até uma força tarefa de pesquisa a ser desenvolvida com a colaboração de outras "organizações internacionais competentes", com o intuito de:

(a) Analisar e definir as principais conotações de liberdade, democracia, lei e igualdade, que surgiram na história da filosofia política e legal; (b) Determinar sua influência prática hoje; (c) Estimar sua importância nas controvérsias ideológicas atuais; e (d) Dar publicidade adequada aos resultados de tal investigação (UNESCO, 1949, p.24).

Este tipo de movimento aponta para alguns resquícios dos impactos causados pela Segunda Guerra Mundial, explicitados nas primeiras proposições de sua Constituição: "desde que a guerra 
começou nas mentes dos homens, é na mente dos homens que a defesa da paz deve ser construída" (UNESCO, 2018, p.5). Ou seja, uma tentativa de reorganizar as nações segundo um sentimento de unidade. No entanto, ele aponta também para uma reorganização da ordem mundial e uma disputa por hegemonia ideológica, política e econômica, personificada pela Guerra Fria.

Nos anos seguintes, a UNESCO disparou e coordenou uma sequência de ações entre seus países membros, inclusive fornecendo por meio do Bureau Internacional de Educação (IBE), uma variedade de materiais impressos, listas de filmes, áudios e suporte educacional para os países membros (VALDERRAMA, 1995).

Segundo Valderrama (1995), apesar das várias discussões sobre a noção de "educação para todos", é somente na Conferência Geral da UNESCO, realizada 1976 em Nairobi (Kênia), que são autorizados oficialmente programas de atividades para a promoção da igualdade de oportunidades na educação. Em novembro de 1982, na 4 à sessão extraordinária da Conferência Geral ocorrida em Paris (França), foi aprovado um conjunto de quinze grandes programas de curto prazo (com validade até 1989):

I: Reflexão sobre problemas mundiais e estudos orientados para o futuro; II: Educação para todos; III: Comunicação a serviço do homem; IV: A formulação e aplicação de políticas educacionais; V: Educação, formação e sociedade; VI: As ciências e sua aplicação ao desenvolvimento; VII: Sistemas de informação e acesso ao conhecimento; VIII: Princípios, métodos e estratégias e ação para o desenvolvimento; IX: ciência, tecnologia e sociedade; X: O ambiente humano e recursos terrestres e marinhos; XI: cultura e futuro; XII: Eliminação do preconceito, intolerância, racismo e apartheid; XIII: Paz, compreensão internacional, direitos humanos e direitos dos povos; XIV: O status das mulheres; e XV: suporte ao programa (VALDERRAMA, 1995, p.277). 
Assim, apesar da "educação para todos" já circular no âmbito das discussões internacionais e em alguns programas locais sobre educação é a partir desta Conferência que o tema efetivamente começa a figurar nas agendas políticas internacionais. Fato este que pode ser justificado pelo próprio avanço das políticas neoliberais de reestruturação do capitalismo, seja pelo aumento do poder e do alcance conferido às organizações multilaterais, seja pelo agravamento das condições de vida nos países periféricos do capitalismo, ou seja pelo próprio desenvolvimento tecnológico e o processo de globalização.

Compreendida como o auge do processo de internacionalização do capitalismo, a globalização foi resultado das políticas neoliberais que buscaram responder à crise estrutural do capitalismo dos anos 1970, marcada pela elevada inflação e pelo início de um período de recessão nos países mais ricos, colocando em questão a própria funcionalidade do modelo keynesiano de estado de bem-estar social. Possuindo como força motriz a revolução tecnológica verificada nos setores de informática e de comunicações desde a década de 1960, a proposta neoliberal para a reestruturação do capitalismo incluiu uma série de aspectos, dentre os quais, a consolidação do domínio do sistema financeiro em um nível global, de processos produtivos mais flexíveis e distribuídos mundialmente, da redução dos custos de transporte e logística, e da elevação da importância das agências financeiras multilaterais (SANTOS, 2002).

Para tanto, foi necessário assegurar o aumento da participação da sociedade civil - entendida segundo a óptica neoliberal como o terceiro setor - e, consequentemente, da participação do capital privado na economia, rumo a um alinhamento com a perspectiva de Estado mínimo. Assim, os próprios processos de descolonização na África e de democratização na América Latina foram fundamentais para o projeto neoliberal. A partir desse movimento, o neoliberalismo passa 
a ser assumido, segundo Dardot e Laval (2016, p.16), como uma "nova razão do mundo":

Devemos entender, por isso, que essa razão é global, nos dois sentidos que pode ter o termo: é "mundial", no sentido de que vale de imediato para o mundo todo; e, ademais, longe de limitar-se à esfera econômica, tende à totalização, isto é, a "fazer o mundo" por seu poder de integração de todas as dimensões da existência humana. Razão do mundo, mas ao mesmo tempo uma "razãomundo".

O neoliberalismo, consumado segundo a noção de globalização, deixa a condição de doutrina e política econômica para se fazer presente como um discurso hegemônico em variadas instâncias da vida pública: desde as concepções de direito, justiça e igualdade, até as formas segundo as quais os países organizam suas políticas públicas e destinam seus investimentos, como o caso da educação.

No entanto, segundo Giddens (2007, p.25), a globalização não se desenvolveu de maneira equitativa, especialmente quanto à distribuição e acesso aos seus benefícios, assumindo culturalmente "uma desagradável aparência de ocidentalização". Na América Latina especificamente, a globalização significou o esgotamento de uma etapa do desenvolvimento econômico que se caracterizou por uma industrialização autocentrada em nível nacional e dependente de financiamento externo; por uma modernização e urbanização aceleradas e descompassadas com a própria capacidade produtiva da indústria; e finalmente, por uma forte presença do Estado interventor, regulando ou substituindo a atividade privada (CORAGGIO, 2000). Este cenário levou muitas das economias à crise, uma vez que não possuíam uma estrutura econômica flexível o suficiente para sustentar a competitividade e a inovação, da mesma forma que a dependência do capital estrangeiro aprofundou a dívida externa destes países e acirrou a situação de pobreza e desigualdade social. 
Enquanto, por um lado, este cenário mobilizou críticas e ações de movimentos sociais, por outro, pressionou as grandes potências mundiais e organizações multilaterais a discutir soluções para amenizar os efeitos negativos da globalização, em certa instância, prejudiciais ao próprio desenvolvimento do projeto neoliberal. Desse modo, as agências financeiras multilaterais passaram a propor um conjunto de condicionalidades de âmbito econômico, político e também ideológicos para os empréstimos aos países periféricos. As políticas de ajuste estrutural, como ficaram conhecidas, incidiram em uma série de reformas e programas de caráter focalizador, ou seja, voltadas à redestinação para os "setores sociais" do gasto público remanescente (CORAGGIO, 2000).

Neste contexto, segundo Valderrama (1995), na Conferência Geral de março de 1984, realizada em Paris, foi assinado um termo que conferiu status de alta prioridade para o programa "educação para todos", especialmente quanto aos pedidos de cooperação vindos dos países em desenvolvimento. Em outubro do mesmo ano, durante a Conferência Internacional sobre Educação, realizada em Genebra (Suíça), foram discutidas possíveis relações entre a "educação para todos" e o contexto das inovações científicas e tecnológicas, salientando a importância do ensino de ciência e de tecnologia na sociedade moderna, a partir do ponto de vista da igualdade de oportunidades (VALDERRAMA, 1995).

Por fim, durante a Conferência Geral realizada em Paris de outubro a novembro de 1989 , foi aprovado o Plano de Ação para a Eliminação do Analfabetismo Até o ano 2000, a ser iniciado no ano de 1990, proclamado, dessa forma, como o Ano Internacional da Alfabetização (VALDERRAMA, 1995) e determinando o teor das propostas realizadas no ano seguinte, na Conferência de Jomtien. 
Paralelamente, a questão da pobreza e o investimento em desenvolvimento humano ganharam centralidade nas discussões de organismos como a Organização das Nações Unidas (ONU), a UNESCO e o Banco Mundial (BM), segundo um discurso de solidarização internacional (CHARLOT, 2013b). Contudo, podemos adjetivar tal solidarização como interesseira, ou segundo Dagnino (2004), como perversa, uma vez que tal discurso se presta apenas à manutenção e sobrevivência do próprio neoliberalismo ao isentar progressivamente o Estado de seu papel como garantidor de direitos e oferecer ao mercado não somente tal atribuição, como também posicioná-lo como representação de democracia, cidadania e justiça. Neste contexto, o BM posiciona a educação como elemento preponderante para a erradicação da pobreza, como pode ser verificado no "Relatório sobre o Desenvolvimento Mundial", subintitulado "A pobreza", publicado em 1990:

\begin{abstract}
Analisando-se a experiência desenvolvimentista, observase que o meio mais eficaz de obter avanços rápidos e politicamente sustentáveis na qualidade de vida dos pobres tem sido a adoção de uma estratégia em dois elementos. O primeiro elemento dessa estratégia é a busca de um modelo de crescimento que garanta o uso produtivo do bem mais abundante entre os pobres - o trabalho. O segundo elemento é o provimento amplo de serviços sociais básicos aos pobres, sobretudo de educação primária, assistência médica básica e planejamento familiar. O primeiro componente cria oportunidades; o segundo capacita o pobre a tirar proveito dessas oportunidades (BANCO MUNDIAL, 1990, p. iii, grifo nosso).
\end{abstract}

A partir deste documento, O BM torna explícito alguns dos propósitos do neoliberalismo em seu "combate à pobreza": primeiramente, garantir mão de obra minimamente qualificada e, em segundo lugar, garantir condições locais favoráveis para o desenvolvimento do mercado. Atrelado a tais propósitos estão presentes os conceitos de justiça distributiva e igualdade de oportunidades, estreitamente vinculadas à lógica meritocrática. Mais 
ainda, ao propor este modelo como "o meio mais eficaz", associa a ideia de equidade às lógicas da eficiência e da eficácia.

Compreendida a trajetória das discussões sobre "educação para todos" no âmbito das propostas internacionais capitaneadas pela UNESCO, com influência direta do Banco Mundial, assim como a conjuntura da globalização e das políticas neoliberais sinalizadas no capítulo de introdução, passaremos a seguir para a análise de alguns trechos da Declaração de Jomtien, particularmente aos que apontam para concepções de igualdade e equidade.

O preâmbulo da Declaração de Jomtien é iniciado com o seguinte texto:

(...) apesar dos esforços realizados por países do mundo inteiro para assegurar o direito à educação para todos, persistem as seguintes realidades:

- mais de 100 milhões de crianças, das quais pelo menos 60 milhões são meninas, não têm acesso ao ensino primário:

- mais de 960 milhões de adultos - dois terços dos quais mulheres - são analfabetos, e o analfabetismo funcional e um problema significativo em todos os países industrializados ou em desenvolvimento:

- mais de um terço dos adultos do mundo não têm acesso ao conhecimento impresso, às novas habilidades e tecnologias, que poderiam melhorar a qualidade de vida e ajudá-los aperceber e a adaptar-se às mudanças sociais e culturais:

- mais de 100 milhões de crianças e incontáveis adultos não conseguem concluir o ciclo básico, e outros milhões, apesar de concluí-lo, não conseguem adquirir conhecimentos e habilidades essenciais (UNESCO, 1998a, preâmbulo). 
Os citados "esforços realizados por países do mundo inteiro" se referem à trajetória percorrida pela UNESCO até a assinatura da presente Declaração. No entanto, como pudemos constatar pela observação histórica desta trajetória, apesar do tema educação para todos já circular nos discursos promovidos pela UNESCO, é somente a partir das Conferências Gerais realizadas em 1982 e 1984 que a "educação para todos" começa a tomar vultos de política pública, ou seja, no sentido do termo utilizado por Höfling (2001, p.31), como o "Estado implantando um projeto de governo, através de programas, de ações voltadas para setores específicos da sociedade". Desse modo, o aparente sentimento de frustração comunicado por este trecho pode ser assumido com um recurso retórico, uma vez que seriam praticamente impossíveis resultados perceptíveis em escala mundial durante os seis ou oito anos que separam a Declaração de Jomtien das referidas Conferências.

Outra questão saliente é o uso de várias nominalizações (FAIRCLOUGH, 2001). É o caso, por exemplo, de "esforços realizados", que atua como uma entidade abstrata, dispensando, uma descrição sobre exatamente que tipo de ações e medidas corresponderia a tais esforços. Contudo, a nominalização mais marcante é justamente "educação para todos". Como pudemos verificar, ao longo da história da própria UNESCO, ela desloca seu sentido desde um objetivo a ser perseguido até se constituir num conceito que abarca não somente tal objetivo, mas também práticas, políticas, programas de governo etc. Esta nominalização pode ser observada no trecho "assegurar o direito à educação para todos". O "direito", como utilizado na frase, deve se referir a um objeto específico ("assegurar o direito a voto", "assegurar o direito à vida" etc.). No caso, o objeto a que se propõe "assegurar o direito" não é a "educação", mas à "educação para todos". 
A frase poderia ser formulada alternativamente como "assegurar o direito de todos à educação". Porém, dessa forma, haveria uma repetição do artigo 26. da Declaração dos Direitos Humanos: "todo ser humano tem direito à instrução" (UNESCO, 1998b, artigo 26), já referido no próprio preâmbulo da Declaração de Jomtien: "há mais de quarenta anos, as nações do mundo afirmaram na Declaração Universal dos Direitos Humanos que toda pessoa tem direito à educação" (UNESCO, 1998a, preâmbulo). Assim, consideramos que a opção pela formulação "assegurar o direito à educação para todos" exprime a intenção da UNESCO em reforçar a "educação para todos" como uma "marca", um conceito ou mesmo um discurso, legitimado pela autoridade representada pela UNESCO, pela tradição de sua trajetória nos discursos desde os anos 1940, por uma avaliação moral, ao associa-lo à equidade e aos direitos humanos (LEEUWEN, 2008).

Nesse sentido, apesar dos "declarantes" se posicionarem como "nós, os participantes da Conferência" (UNESCO, 1998a, preâmbulo), a VOz preponderante no texto é a da UNESCO. Os representantes das várias nações membros da UNESCO ("nós, os participantes"), são apagados, ou intencionalmente isentados das responsabilidades, por exemplo, sobre as "realidades" às quais o trecho faz referência: crianças sem acesso à educação básica, altos índices de analfabetismo, "incontáveis" adultos que não completaram o ciclo básico etc.). O trecho a seguir ilustra esta situação:

Ao mesmo tempo, o mundo tem que enfrentar um quadro sombrio de problemas, entre os quais: o aumento da dívida de muitos países, a ameaça de estagnação e decadência econômicas, o rápido aumento da população, as diferenças econômicas crescentes entre as nações e dentro delas, a guerra, a ocupação, as lutas civis, a violência, a morte de milhões de crianças que poderia ser evitada e a degradação generalizada do meio-ambiente (UNESCO, 1998a, preâmbulo). 
O trecho "o mundo tem que enfrentar" implica um metadiscurso (FAIRCLOUGH, 2001), uma vez que "os participantes da Conferência", que assinam a Declaração se distanciam "do mundo"; fazem parte dele, mas a partir deste recurso, podem falar com uma autoridade gozada pelo próprio distanciamento. Esse tipo de recurso retórico, assim como a nominalização do "mundo" (e da série de problemas elencados na sequência do texto) cria a sensação de que o mundo cria seus próprios problemas, como se fosse uma figura animada, personificada. Desta forma, o "aumento da dívida de muitos países", por exemplo, não estabelece relações com as políticas de ajuste estrutural iniciadas cerca de uma década antes da Declaração de Jomtien, ou com as dívidas contraídas com os países centrais do neoliberalismo que, não obstante, figuram entre "nós, os participantes da Conferência".

Em face de tal "quadro sombrio de problemas", a Declaração prossegue segundo uma perspectiva otimista:

Não obstante, o mundo está às vésperas de um novo século carregado de esperanças e de possibilidades. Hoje, testemunhamos um autêntico progresso rumo à distensão pacífica e de uma maior cooperação entre as nações. Hoje, os direitos essenciais e as potencialidades das mulheres são levados em conta. Hoje, vemos emergir, a todo momento, muitas e valiosas realizações científicas e culturais. Hoje, o volume das informações disponível no mundo - grande parte importante para a sobrevivência e bem-estar das pessoas - é extremamente mais amplo do que há alguns anos, e continua crescendo num ritmo acelerado. Estes conhecimentos incluem informações sobre como melhorar a qualidade de vida ou como aprender a aprender. Um efeito multiplicador ocorre quando informações importantes estão vinculadas com outro grande avanço: nossa nova capacidade em comunicar. Estas novas forças, combinadas com a experiência acumulada de reformas, inovações, pesquisas, e com o notável progresso em educação registrado em muitos países, fazem com que a meta de educação básica para todos - pela primeira vez na história - seja uma meta viável (UNESCO, 1998a, preâmbulo). 
Desse modo, depositam-se na evolução tecnológica e na própria conjuntura geopolítica mundial (a queda do Muro de Berlim e a iminência da dissolução da União Soviética representaram para o bloco capitalista o fim das disputas e a promessa de um futuro pacífico), as possibilidades de efetivação do programa de "educação para todos". O sentimento de otimismo é proporcionado pela modalização de vários dos enunciados presentes no trecho destacado: "extremamente mais amplo", "grande avanço", "notável progresso", "muitas e valiosas realizações".

Este tipo de construção é estratégico para a estrutura do texto. $O$ trecho em questão funciona como um encerramento do preâmbulo, preparando a abertura da Declaração, propriamente dita. Assim, o leitor concebe a leitura dos artigos e propostas segundo tal sentimento a que nos referimos por otimismo. O leitor recebe as informações não somente como uma solução, mas a "mais viável" e possível.

A seguir, analisaremos os artigos 1 e 3 da Declaração de Jomtien, uma vez que sinalizam mais especificamente para as concepções de equidade segundo as quais a própria Declaração se sustenta e, segundo as quais, as agendas de políticas internacionais sobre educação e as políticas públicas nacionais irão se amparar nos anos subsequentes.

Artigo 3. Universalizar o acesso à educação e promover a equidade.

1. A educação básica deve ser proporcionada a todas as crianças, jovens e adultos. Para tanto, é necessário universalizá-la e melhorar sua qualidade, bem como tomar medidas efetivas para reduzir as desigualdades.

2. Para que a educação básica se torne equitativa, é mister oferecer a todas as crianças, jovens e adultos, a oportunidade de alcançar e manter um padrão mínimo de qualidade da aprendizagem. A prioridade mais urgente é 
melhorar a qualidade e garantir o acesso à educação para meninas e mulheres, e superar todos os obstáculos que impedem sua participação ativa no processo educativo. Os preconceitos e estereótipos de qualquer natureza devem ser eliminados da educação.

3. Um compromisso efetivo para superar as disparidades educacionais deve ser assumido. Os grupos excluídos os pobres; os meninos e meninas de rua ou trabalhadores; as populações das periferias urbanas e zonas rurais os nómades e os trabalhadores migrantes; os povos indígenas; as minorias étnicas, raciais e lingüísticas: os refugiados; os deslocados pela guerra; e os povos submetidos a um regime de ocupação - não devem sofrer qualquer tipo de discriminação no acesso às oportunidades educacionais.

4. As necessidades básicas de aprendizagem das pessoas portadoras de deficiências requerem atenção especial. É preciso tomar medidas que garantam a igualdade de acesso à educação aos portadores de todo e qualquer tipo de deficiência, como parte integrante do sistema educativo (UNESCO, 1998a, artigo 3).

A universalização da educação, por sua própria definição (segundo Abbagnano (2007), universal se refere ao que é ou deveria ser válido para todos), já implica a "noção de educação para todos". No entanto, a universalização do acesso, corresponderia à criação de meios legais ou estruturais para todos possam, dessa forma, ter acesso à escola. Nesse sentido, todos os itens compartilham desta preocupação.

A noção de equidade que fundamenta a Declaração torna-se manifesta no item 2, particularmente segundo a ideia de "oportunidade". Ou seja, a equidade é concebida segundo a noção de igualdade de oportunidades. Assim, o próprio sentido da universalização do acesso à educação se estabelece segundo essa mesma noção. A equidade é então definida a partir da igualdade de acesso à escola ou "acesso às oportunidades educacionais" (UNESCO, 1998a, artigo 3) e, dessa forma, intimamente imbricada com um sistema meritocrático. 
Ademais, segundo o item 2, a igualdade de oportunidades de acesso se refere explicitamente a um "padrão mínimo de qualidade da aprendizagem" (UNESCO, 1998a, artigo 3, grifo nosso), refletindo a noção proposta por Rawls (2000) de garantia de limites mínimos ou de um mínimo social, ou seja, um pacote de recursos que um indivíduo necessita para levar uma vida minimamente digna em sua sociedade. Segundo Dubet (2004), seriam garantias com vistas a limitar as desigualdades provocadas nos sistemas meritocráticos.

Nesse sentido, o Artigo 1 da Declaração traduz a noção de "padrão mínimo" segundo a ideia de Necessidades Básicas de Aprendizagem (NEBA):

Artigo 1. Satisfazer as Necessidades Básicas de Aprendizagem

Cada pessoa - criança, jovem ou adulto - deve estar em condições de aproveitar as oportunidades educativas voltadas para satisfazer suas necessidades básicas de aprendizagem. Essas necessidades compreendem tanto os instrumentos essenciais para a aprendizagem (como a leitura e a escrita, a expressão oral, o cálculo, a solução de problemas), quanto os conteúdos básicos da aprendizagem (como conhecimentos, habilidades, valores e atitudes), necessários para que os seres humanos possam sobreviver, desenvolver plenamente suas potencialidades, viver e trabalhar com dignidade, participar plenamente do desenvolvimento, melhorar a qualidade de vida, tomar decisões fundamentadas e continuar aprendendo. A amplitude das necessidades básicas de aprendizagem e a maneira de satisfaze-las variam segundo cada país e cada cultura, e, inevitavelmente, mudam com o decorrer do tempo (UNESCO, 1998a, artigo 1).

Termos e frases como "sobreviver" e "viver e trabalhar com dignidade" ilustram bem a concepção de limites mínimos ou de um mínimo social, expressados por Rawls (2000). Segundo Coraggio (2000), a educação básica passa, a partir de então, a ser definida como 
a educação destinada a satisfação das NEBA, e dessa forma, se configura como,

(...) restrição à degradação humana, um objetivo de, no mínimo, proporcionar aos pobres e despossuídos o indispensável para satisfazer suas necessidades básicas de subsistência, eliminar as fontes da marginalização e desvantagem social. (...) Em tempos de decadência econômica, de austeridade e de demandas sociais e econômicas em competição, é preciso proteger energicamente a educação básica (CORAGGIO, 2000, p.74).

A leitura que Libâneo (2012, p.21) faz desse cenário é mais crítica, no sentido de constatar como a escola pública assume papel, primordialmente, de proporcionar um espaço de convivência e acolhimento social, em contrapartida do atendimento de necessidades mínimas de aprendizagem:

Com apoio em premissas pedagógicas humanistas por trás das quais estão critérios econômicos, formulou-se uma escola de respeito às diferenças sociais e culturais, às diferenças psicológicas de ritmo de aprendizagem, de flexibilização das práticas de avaliação escolar - tudo em nome da educação inclusiva. Não é que tais aspectos não devessem ser considerados; o problema está na distorção dos objetivos da escola, ou seja, a função de socialização passa a ter apenas o sentido de convivência, de compartilhamento cultural, de práticas de valores sociais, em detrimento do acesso à cultura e à ciência acumuladas pela humanidade (LIBÂNEO, 2012, p.21).

A Declaração de Jomtien dialoga com uma série de outros discursos, alguns explícitos e outros não, que se articulam para construir a narrativa até aqui apresentada. Nesse sentido, existem dois problemas efetivos a que esta narrativa faz referência: o primeiro, que milhões de crianças pelo mundo estão excluídas da escola, assim como milhões de adultos também não tem acesso à cultura escrita em suas sociedades; o segundo se refere ao agravamento da pobreza e das desigualdades sociais principalmente nos países periféricos do capitalismo (conforme apresentado no preâmbulo da Declaração de 
Jomtien). Podemos considerar ainda um terceiro problema, marginal a estes dois: em face deste cenário, o mundo está preparado para o "autêntico progresso rumo à distensão pacífica e de uma maior cooperação entre as nações" (UNESCO, 1998a, preâmbulo), segundo o texto da própria Declaração?

Uma resposta mais ampla a estes problemas parte do discurso iluminista da educação a serviço do progresso e do desenvolvimento da sociedade. Em decorrência deste discurso, o primeiro problema pode ser interpretado como causa do segundo e, dessa forma, solucionar o problema do acesso à educação criaria condições para solucionar o problema da pobreza e das desigualdades sociais. Desse modo, universalizar o acesso à educação significaria parte da estratégia proposta pelas organizações multilaterais para a solução destes problemas. O discurso que sustenta essa estratégia é o de que a equidade de acesso à educação é também entendida segundo a perspectiva de igualdade de oportunidades que, por sua vez, é elemento fundamental para a consolidação de um sistema justo, nos termos do discurso meritocrático.

O seguinte trecho da Declaração de Jomtien explicita tais discursos, segundo uma estratégia retórica, um ordenamento lógico dos fatos e a naturalização dos conceitos, que pode muito bem ser interpretada no que Leeuwen (2008) considerou como legitimação pela racionalização:

Relembrando que a educação é um direito fundamental de todos, mulheres e homens, de todas as idades, no mundo inteiro; Entendendo que a educação pode contribuir para conquistar um mundo mais seguro, mais sadio, mais próspero e ambientalmente mais puro, que, ao mesmo tempo, favoreça o progresso social, econômico e cultural, a tolerância e a cooperação internacional; Sabendo que a educação, embora não seja condição suficiente, é de importância fundamental para o progresso pessoal e social; Reconhecendo que 0 
conhecimento tradicional e o patrimônio cultural tem utilidade e valor próprios, assim como a capacidade de definir e promover o desenvolvimento; Admitindo que, em termos gerais, a educação que hoje é ministrada apresenta graves deficiências, que se faz necessário torná-la mais relevante e melhorar sua qualidade, e que ela deve estar universalmente disponível; Reconhecendo que uma educação básica adequada é fundamental para fortalecer os níveis superiores de educação e de ensino, a formação científica e tecnológica e, por conseguinte, para alcançar um desenvolvimento autônomo; e Reconhecendo a necessidade de proporcionar às gerações presentes e futuras uma visão abrangente de educação básica e um renovado compromisso a favor dela, para enfrentar a amplitude e a complexidade do desafio (...)(UNESCO, 1998a, preâmbulo).

A proposta de satisfação das NEBA se amparou, por sua vez, na concepção de equidade como justiça distributiva (RAWLS, 2001). O que implicou, na prática, conjuntamente com as políticas de ajuste estrutural, que os Estados passassem a gerenciar e focalizar os recursos de acordo com as orientações da UNESCO e do Banco Mundial.

Nesse sentido, segundo Coraggio (2000, p.63):

O Banco Mundial promoveu ou capitalizou pesquisas empíricas dos processos de ensino/aprendizagem, que indicam que é conveniente reestruturar o investimento educativo, dando menos peso à infraestrutura e mais aos insumos do próprio processo educativo. (...) As pesquisas orientavam-se para identificar os insumos que resultam mais eficientes como investimento para obter uma educação primária bem sucedida.

Tais insumos segundo Coraggio (2000) corresponderam, na prática, a um currículo, com ênfase na alfabetização e na matemática, livros didáticos, materiais e meios educativos, horas de aula e de permanência na escola, formação de professores, alimentação, transporte escolar etc. 
Nesse sentido, segundo Graciani (2015, p.66),

a escola pública brasileira foi utilizada como centralizadora de uma série de iniciativas que associou o direito humano à Educação e com a afirmação dos direitos humanos de crianças, adolescentes e jovens, tornando-se então, o eixo propulsor de direitos civis e sociais que não foram possíveis de serem assegurados, por exemplo, na família.

Libâneo $(2012)^{9}$ discute que a Declaração de Jomtien se adequou à visão economicista do Banco Mundial, atrelada às lógicas da eficiência e da eficácia. É por esse motivo que a "educação para todos" passou a ser entendida como a "educação dos mais pobres", as "necessidades básicas" como "necessidades mínimas", o "foco na aprendizagem" como "foco na avaliação do rendimento escolar", "condições de aprendizagem" como "organização escolar".

Entretanto, a "visão economicista do Banco Mundial" não pode ser considerada o único fator explicativo desse cenário. Como viemos defendendo, este discurso é também produto de uma série de concepções sobre educação, equidade e justiça, que se tornam hegemônicas (muitas vezes em decorrência da própria forma de utilização destas por organizações como o Banco Mundial ou a UNESCO). Entendemos que existe um propósito (e um interesse) nas concepções do Banco Mundial, por exemplo, no que se refere à educação.

No entanto, consideramos tais interesses e propósitos situados no âmbito da própria hegemonia do discurso político neoliberal que, coadunado aos discursos sobre a globalização, criam um conjuntura internacional que, segundo Burbules e Torres (2000), deixam os Estados sem opção, a não ser se adequar a este conjunto de regras

Baseado em TORRES, Rosa Maria. Educação para todos: a tarefa por fazer. Porto Alegre: Artmed, 2001. 
globais, da qual muitas vezes participa, mas que não são efetivamente de sua própria responsabilidade.

\subsection{Educação para todos e as políticas educacionais brasileiras}

Após a Conferência Mundial Sobre Educação Para Todos de 1990, os diversos países que assinaram a Declaração de Jomtien iniciaram 0 desenvolvimento de políticas públicas de modo universalizar a educação básica, satisfazer as NEBA e se aproximar do objetivo de uma "educação para todos". Segundo Valderrama (1995, p.343), no primeiro biênio após a Declaração de Jomtien foram criados:

118 comitês nacionais, ou pontos de contato oficiais, e uma força-tarefa sobre alfabetização; mais de 300.000 documentos foram produzidos e enviados; mais de cem artigos foram preparados para publicação; respostas foram dadas a mais de 3.000 pedidos de informação e assistência; e milhares de reuniões foram organizadas em todo o mundo.

Neste período foram intensificadas as propostas e pedidos de cooperação com outras agências das Nações Unidas, governos internacionais, organizações não governamentais e mídia (VALDERRAMA, 1995), como um desdobramento direto do artigo 9 ("mobilizar recursos") da Declaração de Jomtien:

Para que as necessidades básicas de aprendizagem para todos sejam satisfeitas mediante ações de alcance muito mais amplo, será essencial mobilizar atuais e novos recursos financeiros e humanos, públicos, privados ou voluntários. Todos os membros da sociedade têm uma contribuição a dar, lembrando sempre que o tempo, a energia e os recursos dirigidos à educação básica constituem, certamente, o investimento mais importante que se pode fazer no povo e no futuro de um país (UNESCO, 1998, artigo 9). 
Tendo em vista a dificuldade, principalmente dos países mais populosos do mundo, nos quais se enquadra o Brasil (além de Indonésia, China, Bangladesh, Egito, México, Nigéria, Paquistão e Índia), quanto ao desenvolvimento de seus programas de "educação para todos", a UNESCO autorizou em 1992 a realização, para dezembro do ano seguinte na cidade de Nova Delhi (Índia), de uma Conferência sobre Educação Para Todos, na qual tais países poderiam discutir as principais dificuldades encontradas na efetivação de seus programas, assim como estabelecer parcerias e propor soluções.

A Declaração de Nova Delhi (como convencionaremos denominar aqui a Declaração de Nova Delhi Sobre Educação Para Todos) possui um formato mais simples do que se comparada com a Declaração de Jomtien. Basicamente, a Declaração de Nova Delhi reitera a sua predecessora:

Nós, os líderes dos nove países em desenvolvimento de maior população do mundo, reiteramos por esta Declaração nosso compromisso de buscar com zelo e determinação as metas definidas pela Conferência Mundial sobre Educação para Todos e pela Cúpula Mundial da Criança, realizadas em 1990 (UNESCO, 1998c, p.1).

E reconhece algumas das dificuldades enfrentadas, principalmente oriundas do tamanho de seus territórios e populações:

as pressões demográficas impõem um ônus por demais pesado à capacidade dos sistemas educacionais e impedem as reformas e melhorias necessárias; além do mais, dada a estrutura etária dos nossos países, esse processo continuará no decorrer da próxima década (UNESCO, 1998c, p.1).

Da análise destes trechos é possível notar uma maior exposição dos sujeitos da Declaração de Nova Delhi em comparação com a Declaração de Jomtien. Enquanto na Declaração de Jomtien os declarantes se posicionaram como "nós, os participantes da 
Conferência", na Declaração de Nova Delhi, os declarantes são bastante explícitos: "nós, os líderes dos nove países em desenvolvimento de maior população do mundo" (nominalmente discriminados no texto do documento).

Por um lado este fato pode ser interpretado pelo número de participantes em ambas as conferências, o que tornaria exaustiva a nominação de cada participante de Jomtien. Por outro lado, pelo próprio caráter de cada declaração: em Jomtien, o objetivo foi lançar mundialmente as bases para uma agenda de políticas e programas sobre a educação, não sendo necessária a personificação em torno de uma ou outra nação, uma vez que a UNESCO se assume como a voz preponderante no texto. Já em Nova Delhi, apesar da conferência ser organizada pela UNESCO e os participantes também dela serem membros, não é a sua voz que predomina no texto. Dada a particularidade destes países, eles se colocam como uma instância a parte e pedem ajuda para os demais países membros e organizações multilaterais. Nesse sentido, é fundamental que fique muito claro quem são os sujeitos da Declaração.

Nesse sentido, o referido pedido de ajuda se expressou na declaração de forma muito mais impositiva:

PORTANTO, convocamos:

4.1 os colaboradores internacionais para que aumentem substancialmente o apoio prestado ao nosso esforço de ampliar nossas capacidades nacionais em benefício da expansão e melhoria dos serviços de educação básica;

4.2 as instituições financeiras internacionais para que, sob o prisma de ajustes estruturais, reconheçam a educação como investimento crítico isento da imposição de tetos preestabelecidos e que promovam um clima internacional capaz de permitir aos países sustentar seu desenvolvimento socioeconômico; 
4.3 a comunidade de nações para que se junte a nós na reafirmação do nosso compromisso com a meta de educação para todos e na intensificação de seus esforços para alcançarmos nossa meta até o ano 2000 ou o mais breve possível (UNESCO, 1998c, p.2, grifo nosso).

Dessa forma, "sob o prisma de ajustes estruturais", a política educacional brasileira passou a estar condicionada pelas propostas não somente da UNESCO e das concepções apresentadas pela Declaração de Jomtien, mas principalmente às orientações e entendimentos sobre a educação do próprio Banco Mundial. Segundo Mota Jr e Maués (2014), a partir da política de ajustes estruturais, o Banco Mundial intencionava a inserção do Brasil (e demais países periféricos) no processo de globalização neoliberal.

Desse modo, segundo Mota Jr e Maués (2014), a radicalização das políticas neoliberais na economia brasileira teve início com o governo de Fernando Collor de Melo, entre 1990 e 1992, marcada pelo avanço das privatizações, pela precarização do sistema público em diferentes níveis, o crescente endividamento do Estado e a deterioração do já precarizado Estado Social. Entre 1995 e 2002, durante o governo de Fernando Henrique Cardoso, segundo Mota Jr e Maués (2014), ocorre um efetivo alinhamento estratégico do Ministério da Educação com o Banco Mundial, explicitado pela própria composição de seus altos cargos, todos com passagens pelos quadros do Banco Mundial, seja como diretores regionais ou como consultores.

Nesse sentido, a política educacional brasileira ao longo dos anos 1990 é marcada pela crescente privatização do ensino superior, o desenvolvimento de macroavaliações e a descentralização na oferta e na gestão dos sistemas educacionais (MOTA JR, MAUÉS, 2014; ALTMANN, 2002). Nesse sentido, as propostas de descentralização, entendidas pelo Banco Mundial como prioritárias, ocorreram segundo 
várias perspectivas, caracterizadas pela transferência de responsabilidade do governo nacional para os municípios (municipalização), para organizações não governamentais (delegação) ou para o setor privado (privatização) (LOCATELLI, 2011).

Paralelamente, segundo Altmann (2002), os sistemas de avaliação da educação se atrelam aos processos de descentralização segundo o duplo propósito de assegurar qualidade e fornecer dados sobre o sistema educacional como um todo. Em outras palavras, por um lado, a criação de macroavaliações como o Saeb ao longo dos anos 1990, se insere no próprio discurso Banco Mundial, focado em meios eficazes e eficientes de formação de mão de obra, por outro, tais avaliações produzem estatísticas e indicadores acerca da eficiência com que o país promove a equidade na educação (ALTMANN, 2002).

O Plano Decenal de Educação Para Todos, publicado em 1993, se inseriu neste contexto geral. Concebido como uma proposta de médio/longo prazo, a sua elaboração ocorreu depois de variados debates ocorridos desde 1990 acerca das dificuldades e possibilidades de se cumprir os objetivos de "educação para todos" propostos pela Declaração de Jomtien. A Semana Nacional de Educação Para Todos, ocorrida em Brasília, de 10 a 14 de maio de 1993 (alguns meses antes da Conferência de Nova Delhi), consolidou tais debates e contribuiu para a formulação deste plano (BRASIL, 1993, p.12).

O Plano Decenal se propõe a "fundamentar os processos de detalhamento e operacionalização [do programa educação para todos], constituindo referência para os correspondentes planos estaduais e municipais". Desse modo, conjuntamente com a Lei de Diretrizes e Bases da Educação Nacional (Lei n. 9.394/96), neles podem ser entendidas as formas como os discursos sobre equidade se aproximam 
da prática, uma vez que são documentos basilares para a produção de políticas públicas.

No Plano Decenal são reiterados os princípios gerais da Declaração de Jomtien. No entanto, a seguir discutiremos algumas diferenças observadas.

Um dos objetivos da Declaração de Jomtien é expresso como "universalizar o acesso à educação e promover a equidade" (UNESCO, 1998a, artigo 3). Conforme discutido anteriormente, segundo uma lógica neoliberal de justiça e igualdade, a universalização do acesso à educação corresponde à criação de oportunidades iguais de acesso para todos à educação. Esta condição, por sua vez, visa equalizar os "pontos de partida" para cada indivíduo tomar parte, de forma "justa", no sistema meritocrático. Nesse sentido, a partir da frase destacada, pode-se inferir que a universalização é uma etapa ou um requisito para a promoção da equidade. Interpretação esta, justificada pela própria Declaração de Jomtien: "para que a educação básica se torne equitativa, é mister oferecer a todas as crianças, jovens e adultos, a oportunidade de alcançar e manter um padrão mínimo de qualidade de aprendizagem" (UNESCO, 1998a, artigo 3). Ou seja, para se atingir a equidade é necessário oportunizar o acesso de todos à educação (universalização).

O Plano Decenal descreve um objetivo equivalente: "universalizar, com equidade, as oportunidades de alcançar e manter níveis apropriados de aprendizagem e desenvolvimento". Nesta formulação, a equidade não é um fim para a universalização, mas uma qualidade desejável da mesma. Nesse sentido, enquanto na Declaração de Jomtien a universalização é tida como um conceito absoluto, que implica oferecer igual oportunidade de acesso a todos, balizada segundo a garantia de um padrão mínimo; no Plano Decenal, tal qual 
formulada a frase, pode-se inferir que a universalização não é um conceito absoluto, ou seja, podem coexistir vários graus ou níveis de universalização que, por sua vez, precisam ser equalizados.

Nesse sentido, o objetivo proposto pela Declaração de Jomtien sugere a existência a priori de um sistema educacional com a capacidade oferecer um padrão mínimo e que, para criar a equidade basta que se criem condições (legais, por exemplo) para que o acesso a este sistema seja universalizado. No caso do texto do Plano Decenal, uma possível interpretação é que não existe tal um sistema educacional a priori. Assim, a construção deste sistema ocorre paralelamente à universalização do acesso a ele. O próprio Plano Decenal descreve um recorte que ilustra a heterogeneidade do sistema educacional brasileiro na época:

É elevada a heterogeneidade das condições de oferta entre as várias regiões e dentro das regiões, entre as redes estadual e municipal e entre as escolas urbanas e rurais. Uma parte considerável dos estudantes, especialmente na zona rural, é atendida em escolas que não oferecem as oito séries do primeiro grau. Cerca de 4,6 milhões de alunos estudam em escolas que funcionam com três ou quatro turnos, em jornadas escolares reduzidas, recebendo, portanto, insuficiente atenção pedagógica. Há cerca de 230 mil escolas que não contam com os equipamentos e materiais mínimos para efetivação do ensino; essas escolas cobrem apenas $25 \%$ do total de alunos e situam-se, em sua maioria, na zona rural. Dotá-las desses meios e mesmo supri-las de recursos de educação a distância não seria tarefa de grande dificuldade. Nas 50 mil escolas com mais de quatro salas de aula e seriação completa, que atendem a mais de três quartos dos alunos, a precariedade dos meios é menos aguda. Há, no entanto, problemas de conservação dos prédios e de qualidade das instalações e dos meios instrucionais (BRASIL, 1993, p.20).

Nesse sentido, o Plano Decenal atribui ao "princípio de equalização de oportunidades educacionais" (BRASIL, 1993, p.20) o complemento "com qualidade", ou seja, reconhece que a igualdade de acesso ao sistema por si só não garante o acesso aos "padrões 
mínimos" a que UNESCO e Banco Mundial se referem, dada a desigualdade de condições entre redes, regiões, estados etc.

\subsection{Educação Para Todos e o ensino de matemática}

A matemática possui uma posição privilegiada nos currículos escolares e nos discursos educacionais, conforme apontado no texto dos Parâmetros Curriculares Nacionais de 1997:

A constatação da sua importância apoia-se no fato de que a Matemática desempenha papel decisivo, pois permite resolver problemas da vida cotidiana, tem muitas aplicações no mundo do trabalho e funciona como instrumento essencial para a construção de conhecimentos em outras áreas curriculares. Do mesmo modo, interfere fortemente na formação de capacidades intelectuais, na estruturação do pensamento e na agilização do raciocínio dedutivo do aluno (BRASIL, 1997, p.15).

No entanto, a sua presença nos principais marcos sobre "educação para todos" discutidos até aqui, permanece discreta. $\mathrm{Na}$ Declaração de Jomtien, a única referência pode ser observada em:

Cada pessoa - criança, jovem ou adulto - deve estar em
condições de aproveitar as oportunidades educativas
voltadas para satisfazer suas necessidades básicas de
aprendizagem. Essas necessidades compreendem tanto
os instrumentos essenciais para a aprendizagem (como a
leitura e a escrita, a expressão oral, o cálculo, a
solução de problemas) (...) (UNESCO, 1998 a, artigo 1 ,
grifo nosso).

No Plano Decenal, a referência à matemática é realizada no mesmo contexto, ao recuperar este mesmo trecho da Declaração de Jomtien: 
Satisfazer as necessidades básicas de aprendizagem (...), garantindo oportunidades a todos de aquisição de conteúdos e competências básicas:

No domínio cognitivo: incluindo habilidades de comunicação e expressão oral e escrita, de cálculo e raciocínio lógico, estimulando a criatividade, a capacidade decisória, habilidade na identificação e solução de problemas e, em especial, de saber como aprender (BRASIL, 1993, p.22, grifo nosso).

Este fato é compreensível, uma vez que tais documentos apontam para a questão da educação para todos segundo uma perspectiva geral, não sinalizando como cada disciplina específica deveria tratar desse problema. Nesse sentido, a preocupação principal da Declaração de Jomtien, assim como Plano Decenal, foi propor soluções para a questão da universalização do ensino primário. A alfabetização é tida como prioritária, uma vez que é considerada segundo o discurso da cidadania, no qual se apropriar da cultura letrada é fundamental para a constituição do indivíduo em cidadão.

No entanto, é possível inferir a posição da matemática na Declaração de Jomtien a partir das discussões que se desdobraram no âmbito da educação matemática entre as décadas de 1970 e 1980, convergindo no programa especial na quinta edição do Congresso Internacional de Educação Matemática (ICME) de 1984, realizado com apoio da UNESCO, sob o título de "Matemática Para Todos". Nele, foram reconhecidas uma série de problemas e desafios como a seletividade cultural e a distribuição desigual do ensino de matemática pelo mundo (GATES, VISTRO-YU, 2003).

O seguinte trecho, retirado da introdução do relatório produzido no Congresso ${ }^{10}$, permite observar como o ensino da matemática é

10 DAMEROW, Peter et al. (ed.). Mathematics for all: problems of cultural selectivity and unequal distribution of mathematical education and future perspectives on mathematics teaching for the majority. Report and papers presented in theme group I, 'Mathematics for All' at the 5th International Congress on Mathematical Education, Adelaide, August 24-29, 1984. UNESCO, 1984. 
considerado num contexto mas geral:

Muitos fatores trouxeram uma mudança no geral na situação da educação matemática. Estes incluem a universalização do ensino básico nos países em desenvolvimento, a universalização do ensino secundário em países industrializados (onde também houve o aumento da demanda por competências matemáticas, face a um mundo cada vez mais tecnologicamente e cientificamente orientado) (...) (DAMEROW et al., 1984, p.3).

Em vista desse contexto, as discussões contidas no relatório podem ser resumidas, conforme Gates e Vistro-Yu (2003), segundo duas grandes propostas. A primeira divide a matemática em dois blocos, um primeiro, mais instrumental, dedicado à maioria dos alunos e ensinado nos primeiros anos de escolarização, no qual os alunos aprenderiam as operações fundamentais e técnicas de resolução de problemas. O segundo bloco seria destinado aos que desejassem se especializar em matemática, considerando-a em uma perspectiva mais abstrata, tomada a partir de suas estruturas e rigor lógico e formal. A segunda proposta mantinha a matemática da forma como já vinha sendo trabalhada na maioria dos currículos, mas buscaria encontrar maneiras mais efetivas de ensina-la "para todos". Isso implicava questionar o modelo de currículo europeu, desenhado no século XIX, e sua pertinência ou relevância para toda e qualquer cultura.

Em vista disso, é possível verificar como os textos do relatório produzido pelo ICME-5 e da Declaração de Jomtien se relacionam interdiscursivamente. Em primeiro lugar, existe um discurso comum a ambos os documentos no sentido de que a meta da universalização do ensino básico estaria orientada aos países em desenvolvimento, estando os países industrializados voltados para a universalização do ensino secundário.

Como, segundo o relatório do ICME-5, o ensino de matemática 
associado à formação de indivíduos "competentes matematicamente", voltado a suprir a "demanda" criada por um "mundo cada vez mais tecnologicamente e cientificamente orientado", se daria a princípio nos países industrializados, não haveria sentido de que tal discussão fossem incorporada à Declaração de Jomtien. Por outro lado, nota-se como a primeira grande proposta observada por Gates e Vistro-Yu (2003) no relatório do ICME-5, é apropriada pelo discurso da Declaração de Jomtien, segundo a perspectiva das NEBA, ao resumir o ensino de matemática "para todos" a partir das operações fundamentais e da resolução de problemas a elas relacionados.

Nesse sentido, é importante assinalar como o entendimento sobre as funções sociais da matemática estão em constante disputa, seja na esfera acadêmica, seja nos discursos veiculados no âmbito internacional, dos governos e das agências multilaterais.

Nesse ínterim, é particularmente interessante o caso do artigo publicado por Aaron Benavot (atualmente diretor dos Relatórios de Monitoramento Global sobre Educação Para Todos, da UNESCO) em 1991, resultado do estudo encomendado pelo Banco Mundial sobre os currículos de educação básica de 60 países durante o período entre 1960 e 1985 e seu impacto efetivo no desenvolvimento econômico. Benavot (1991, p.1) declara como uma de suas principais preocupações o impacto que a matemática e as ciências poderiam ter no desenvolvimento econômico: "matemática e educação científica, duas áreas temáticas que muitos acreditam ser especialmente pertinentes para a prosperidade econômica das nações, são destacadas ao longo do artigo". Curiosamente, a análise dos dados apontou que "não há evidências de que as horas de instrução dedicadas à matemática elementar tenham impacto significativo no crescimento econômico" (BENAVOT, 1991, p.17) e que a matemática "têm associações positivas, mas não especialmente fortes, com o 
desenvolvimento" (BENAVOT, 1991, p.12).

Benavot (1991, p.10) justifica os resultados, aparentemente contraditórios em relação ao discurso da importância da matemática para o progresso da sociedade e o desenvolvimento tecnológico, a partir da hipótese expressada pela questão: "será que os dados oficiais mais obscurecem do que revelam?".

Se as políticas oficiais no âmbito do currículo são simplesmente afirmações ideológicas desenvolvidas pelos líderes nacionais sobre educação, de modo a refletir apropriadamente os parâmetros das agências doadoras internacionais (que tomam decisões críticas quanto aos empréstimos e subvenções), então nossos dados podem mostrar nada além de padrões superficiais de concordância global (BENAVOT, 1991, p.12).

Desse modo, Benavot (1991), assumindo o ponto de vista das "agências doadoras internacionais", culpabiliza os países por mascarar a situação real de seus sistemas educacionais de modo a se manter dentro dos "parâmetros" destas agências e, dessa forma, garantir os empréstimos ou financiamentos. Tacitamente, Benavot (1991) sinaliza para a necessidade de que estas agências criem formas de avaliação da eficiência com que tais países desenvolvem seus sistemas educacionais.

Valero (2017) aponta como tais agências posicionam a educação como elemento fundamental para o progresso, no sentido de qualificar a mão de obra com vistas à inovação, produtividade, desenvolvimento etc. Se recuperarmos a concepção exposta pelo Banco Mundial no relatório "A Pobreza", citado anteriormente, segundo a qual o desenvolvimento depende da exploração do "bem mais abundante dos pobres", ou seja, o trabalho, verificamos que tal discurso se mantém.

No entanto, uma vez que a educação se constitui como "uma porta de entrada para o emprego e a inclusão social" (Comissão 
Europeia, 2012, apud Valero, 2017), os discursos sobre a relação entre mercado de trabalho e educação assumem mais claramente as relações entre escolaridade e empregabilidade, assim como entre empregabilidade e status ou mobilidade social.

A matemática, por sua vez, é associada a este discurso a partir de uma função bastante peculiar, associada ao desenvolvimento tecnológico, como já sinalizado no documento "Matemática para Todos":

Causa preocupação o fato de não ter aumentado o número de estudantes nos níveis mais altos de proficiência, o que pode indicar que o país não está se preparando para formar adequadamente estudantes para funções mais complexas, que demandam grande conhecimento da matemática, como as áreas da engenharia (OCDE, 2012, p.22).

Contudo, Valero (2017) sinaliza ao fato de que este não é o único motivo pelo qual a matemática pode ser considerada fundamental na sociedade contemporânea: o ensino de matemática confere às crianças qualidades como racionalidade, objetividade, universalidade e subjetividade. Ou seja, a matemática poderia empoderar os alunos segundo sua característica intrínseca de sintetizar a lógica racional. Skovsmose e Valero (2002) propõem outros pontos de vista utilizados para justificar a importância de se aprender matemática: psicológico (associado a experiência de aprender matemática, no desenvolvimento do raciocínio matemático, naquilo que os alunos possam compreender e fazer sentido); sociocultural (os alunos devem experimentar a relevância e o significado da sua aprendizagem em relação à sua experiência sociocultural; assim, o poder das ideias matemáticas está relacionado às possibilidades pelas quais os alunos interpretam e conceituam - explícita ou implicitamente, consciente ou inconscientemente - as suas condições futuras de vida dado o ambiente social, cultural, econômico e político em que se vivem). 
Tomando este cenário como pano de fundo, observaremos a seguir como os Parâmetros Curriculares Nacionais (PCN) para os primeiro e segundo ciclos (publicado em 1997) e para os terceiro e quarto ciclos (publicado em 1998) contemplam o ensino de matemática. Nesse sentido, cabe ressaltar que a proposta de criação de um currículo mínimo comum para a educação nacional já estava preconizada na Constituição da República de 1988:

Serão fixados conteúdos mínimos para o ensino fundamental, de maneira a assegurar formação básica comum e respeito aos valores culturais e artísticos, nacionais e regionais (BRASIL, 1988, artigo 210).

Da mesma forma como na LDB de 1996:

A União incumbir-se-á de: (...) IV - estabelecer, em colaboração com os Estados, o Distrito Federal e os Municípios, competências e diretrizes para a educação infantil, o ensino fundamental e o ensino médio, que nortearão os currículos e seus conteúdos mínimos, de modo a assegurar formação básica comum (BRASIL, 2006, artigo 9).

Segundo Bonamino e Martínez (2002, p.373), a produção dos PCN foi marcada pelas disputas entre o Ministério da Educação (MEC) e o Conselho Nacional de Educação (CNE), num processo caracterizado pela "excessiva centralização das decisões no governo federal e escasso envolvimento das outras instâncias políticoinstitucionais e da comunidade científica com a educação básica". Para Bonamino e Martínez (2002, p.382):

O fato mais relevante e que mais chamou nossa atenção durante a leitura dos PCN é que, apesar da existência de documentos do CNE que tratam das diretrizes curriculares para a educação nacional, como a Exposição de Motivos que fundamentam as $D_{C N}{ }^{11}$ e das próprias DCN, O MEC optou por ignorar essas referências,

11 As Diretrizes Curriculares Nacionais foram desenvolvidas pela CNE com o intuito de estabelecer uma base nacional comum para orientar a organização, articulação, o desenvolvimento e a avaliação das propostas pedagógicas de todasas redes de ensino brasileiras (BRASIL, 2013). 
preferindo basear-se em documentos legais de caráter mais geral.

Apesar de Bonamino e Martínez (2002) não delimitarem exatamente quais seriam os citados "documentos legais de caráter mais geral", o texto introdutório dos PCN explicita as referências às Declarações de Jomtien e de Nova Delhi, assim como ao Plano Decenal de Educação para Todos. Desse modo, em vista da linha de raciocínio estabelecida nesta tese, a análise dos PCN será importante para a compreensão de como os discursos presentes nestes documentos se apresentam no âmbito dos currículos nacionais de matemática.

No entanto, como os PCN se dividem em vários documentos, convencionaremos denominar neste texto os PCN de Matemática para 0 primeiro e segundo ciclos por PCN1/2, assim como os PCN de Matemática para o terceiro e quarto ciclos por $P C N 3 / 4$. Tal distinção, de cunho prático, será necessária uma vez que buscaremos realizar paralelos entre as concepções e discursos presentes nos dois documentos.

Nos textos de apresentação de ambos os documentos, é possível constatar elementos de interdiscursividade com o trecho do documento "Matemática para Todos", destacado no início deste subcapítulo. Para facilitar a análise, iremos recuperar o trecho citado a seguir:

Muitos fatores trouxeram uma mudança no geral na situação da educação matemática. Estes incluem a universalização do ensino básico nos países em desenvolvimento, a universalização do ensino secundário em países industrializados (onde também houve 0 aumento da demanda por competências matemáticas, face a um mundo cada vez mais tecnologicamente e cientificamente orientado) (...) (DAMEROW et al., 1984, p.3).

No PCN1/2 ressalta-se a importância do aprendizado da matemática tendo em vista a participação em uma sociedade que "se 
utiliza, cada vez mais, de conhecimentos científicos e recursos tecnológicos":

A Matemática é componente importante na construção da cidadania, na medida em que a sociedade se utiliza, cada vez mais, de conhecimentos científicos e recursos tecnológicos, dos quais os cidadãos devem se apropriar (BRASIL, 1997b, p.19).

Ambos os trechos associam o ensino de matemática a uma sociedade cada vez mais determinada pela ciência e pela tecnologia. Contudo, a distinção observada entre os textos ocorre pelo fato de que, enquanto o documento "Matemática para Todos" atribui o aprendizado de matemática ao cumprimento de uma demanda criada pela sociedade, o PCN1/2 atribui a este mesmo aprendizado a função de formação para a cidadania e de inserção na sociedade como cidadão. Nesse sentido, entendemos a existência de uma distância temporal de mais de uma década entre a publicação de ambos os documentos, mas ainda assim podemos inferir que tal diferenciação é fruto dos próprios contextos a que se referem os textos. No caso de "Matemática para Todos", o texto delimita claramente que esta é uma preocupação dos ditos "países industrializados", que, ao menos teoricamente, superaram a questão da universalização do ensino básico. Em um país como o Brasil, de profundas desigualdades sociais, aprender matemática é entendido como um meio para a participação em uma "sociedade que utiliza, cada vez mais, conhecimentos científicos e recursos tecnológicos" e, dessa forma, adquirir cada vez mais o status de cidadão.

No caso do $\mathrm{PCN} 3 / 4$, a referência à tecnologia e à ciência não é feita, optando por indicações mais gerais "nova realidade" e "diversos campos da atividade humana":

Discussões no âmbito da Educação Matemática que acontecem no Brasil e em outros países apontam a 
necessidade de adequar o trabalho escolar a uma nova realidade, marcada pela crescente presença da Matemática em diversos campos da atividade humana (BRASIL, 1998, p.19).

$\mathrm{Na}$ sequência da leitura dos documentos, ambos apresentam a seção "O conhecimento matemático: principais características". Nesse aspecto, pudemos verificar como ambos os documentos apresentam características distintas. Enquanto o PCN1/2 caracteriza a matemática segundo seu rigor lógico e estrutura abstrata:

Mesmo com um conhecimento superficial da Matemática, é possível reconhecer certos traços que a caracterizam: abstração, precisão, rigor lógico, caráter irrefutável de suas conclusões, bem como o extenso campo de suas aplicações (BRASIL, 1997b, p.23).

Assim, mesmo assumindo que o conhecimento matemático tem sua origem em problemas "do mundo real" (BRASIL, 1997b, p.23), o PCN1/2 mantém o foco em uma matemática entendida como um exercício puramente mental: "a Matemática move-se quase exclusivamente no campo dos conceitos abstratos e de suas interrelações" (BRASIL, 1997b, p.23). Ou ainda:

O conhecimento matemático é fruto de um processo de que fazem parte a imaginação, os contraexemplos, as conjecturas, as críticas, os erros e os acertos (BRASIL, 1997b, p.23).

Ao longo deste trecho, é possível verificar o comprometimento do autor com estas ideias a partir da utilização de série de termos modalizados: "[a matemática] converteu-se em um imenso sistema de variadas e extensas disciplinas"; "o extenso campo de suas aplicações"; "alto grau de minuciosidade, que os torna incontestáveis e convincentes" (BRASIL, 1997b, p.23, grifo nosso).

Por fim, no próprio campo da interdiscursividade é possível notar como a voz presente neste texto se afilia a um discurso positivista: "[a 
matemática] como as demais ciências, reflete as leis sociais e serve de poderoso instrumento para o conhecimento do mundo e domínio da natureza" (BRASIL, 1997b, p.23, grifo nosso).

Por outro lado, a concepção de matemática apresentada no $\mathrm{PCN} 3 / 4$ assume uma direção distinta:

\begin{abstract}
A Matemática caracteriza-se como uma forma de compreender e atuar no mundo e o conhecimento gerado nessa área do saber como um fruto da construção humana na sua interação constante com o contexto natural, social e cultural. Esta visão opõe-se àquela presente na maioria da sociedade e na escola que considera a Matemática como um corpo de conhecimento imutável e verdadeiro, que deve ser assimilado pelo aluno (BRASIL, 1998, p.24).
\end{abstract}

Em PCN3/4, existe uma preocupação em constantemente aproximar a matemática do seu aspecto como "construção humana" ou como "invenção humana" Da mesma forma, a crítica feita à concepção de uma matemática "imutável" é referida variadas vezes: "a Matemática é uma ciência viva"; "desenvolveu-se seguindo caminhos diferentes nas diversas culturas"; "não há uma via única ligando a Matemática e o mundo físico" e "o saber matemático como algo flexível e maleável (BRASIL, 1998, pp.24-26). A crítica realizada à visão presente na "maioria da sociedade e na escola" de que a matemática é um "conhecimento imutável e verdadeiro" é no mínimo curiosa, uma vez que assume uma abordagem oposta da apresentada em PCN1/2.

Entretanto, apesar de partirem de concepções distintas acerca do "conhecimento matemático", ambos os documentos convergem em torno de um ponto particular: a função da matemática na "construção da cidadania".

Nesse sentido, a formação para a cidadania, ganha nos PCN a possibilidade de uma manifestação mais prática no âmbito das aulas de 
matemática a partir dos denominados temas transversais. A sua inclusão nos PCN se deu, em parte, pela necessidade de integrar os conteúdos disciplinares e superar a fragmentação do conhecimento escolar, mas também pela própria conjuntura dos anos 1990: por um lado, a redemocratização do país propiciava a inclusão de temas como cidadania, democracia, diversidade nos currículos, por outro, havia a pressão do próprio cenário da globalização, demandando a formação de outro tipo de cidadão "para o mundo" (WENCESLAU E SILVA, 2017).

$O$ texto dos $\mathrm{PCN} 1 / 2$ pondera tal fragmentação dos conhecimentos, assim como o aparente "isolamento" do ensino de matemática:

Centrado em si mesmo, limitando-se à exploração de conteúdos meramente acadêmicos, de forma isolada, sem qualquer conexão entre seus próprios campos ou com outras áreas de conhecimento, o ensino dessa disciplina pouco tem contribuído para a formação integral do aluno, com vistas à conquista da cidadania (BRASIL, 1997b, p.26).

No texto dos PCN3/4, por sua vez, é salientada a necessidade dos currículos incluírem também "questões sociais":

A proposta de trabalhar com questões de urgência social
numa perspectiva de transversalidade aponta para o
compromisso a ser partilhado pelos professores das
áreas, uma vez que é o tratamento dado aos conteúdos
de todas as áreas que possibilita ao aluno a
compreensão de tais questões, o que inclui a
aprendizagem de conceitos, procedimentos e o
desenvolvimento de atitudes (BRASIL, 1998, p.28).

No entanto, enquanto ambos os documentos apontam para temas como ética, diversidade sexual, meio ambiente, pluralidade cultural e saúde, especificamente o $\mathrm{PCN} 3 / 4$ propõe também o tema "trabalho e consumo": 
Para atender as demandas do trabalho contemporâneo é inegável que a Matemática pode dar uma grande contribuição à medida que explora a resolução de problemas e a construção de estratégias como um caminho para ensinar e aprender Matemática na sala de aula. Também o desenvolvimento da capacidade de investigar, argumentar, comprovar, justificar e o estímulo à criatividade, à iniciativa pessoal e ao trabalho coletivo favorecem o desenvolvimento dessas capacidades (BRASIL, 1998, p.28).

Da mesma forma, no trecho abaixo:

Falar em formação básica para a cidadania significa refletir sobre as condições humanas de sobrevivência, sobre a inserção das pessoas no mundo do trabalho, das relações sociais e da cultura e sobre 0 desenvolvimento da crítica e do posicionamento diante das questões sociais. Assim, é importante refletir a respeito da colaboração que a Matemática tem a oferecer com vistas à formação da cidadania (BRASIL, 1998, p.24, grifo nosso).

Mesmo não aparecendo como um tema transversal no documento a relação entre cidadania e mundo do trabalho também é ponderada no PCN1/2:

O papel que a Matemática desempenha na formação básica do cidadão brasileiro norteia estes Parâmetros. Falar em formação básica para a cidadania significa falar da inserção das pessoas no mundo do trabalho, das relações sociais e da cultura, no âmbito da sociedade brasileira (BRASIL, 1997b, p.25, grifo nosso).

A relação também se manifesta em outros documentos, como na Constituição de 1988:

A educação, direito de todos e dever do Estado e da família, será promovida e incentivada com a colaboração da sociedade, visando ao pleno desenvolvimento da pessoa, seu preparo para o exercício da cidadania e sua qualificação para o trabalho. (BRASIL, 1988, artigo 205). 
Assim como na LDB, parafraseando o Artigo 205 da Constituição da República:

A educação, dever da família e do Estado, inspirada nos princípios de liberdade e nos ideais de solidariedade humana, tem por finalidade o pleno desenvolvimento do educando, seu preparo para o exercício da cidadania e sua qualificação para o trabalho BRASIL, 2006, artigo 2).

Porém, nota-se que enquanto os dois últimos trechos aproximam cidadania e qualificação para o trabalho ao tratar ambos no mesmo conjunto de funções da educação, os trechos extraídos dos PCN estabelecem entre tais termos uma relação mais direta. Ao propor que "falar em formação básica para a cidadania significa falar da inserção das pessoas no mundo do trabalho" o PCN1/2 passa a não distinguir mais ambas as noções de forma independente.

Esta relação direta entre trabalho e cidadania, segundo Silva (1995), pode ser associada à concepção de cidadania social, entendida por sua vez, a partir das concepções de cidadania civil (baseada nas concepções liberais de propriedade, privacidade etc.) e cidadania política (associada a direitos políticos, como o voto e a participação nas decisões da esfera pública).

(...) historicamente o sujeito típico da cidadania social é o cidadão-trabalhador, tanto na condição de pagador de impostos quanto na de recebedor de serviços. Ambas as condições dependem da atividade do trabalhador, ou seja do trabalho. O trabalho entra aqui como um elemento fundamental, de um lado, para a formação da identidade do indivíduo no domínio privado da família e no espaço público do sistema educacional e, de outro, para a sua participação na produção social e no exercício do poder político (SILVA, 1995, p.9).

Um dos riscos do excessivo direcionamento dos currículos de matemática nesta direção é justamente de cair no paradoxo da cidadania (SKOVSMOSE E VALERO, 2002), ou seja, ao reduzir o 
ensino à adequação a determinadas normas sociais e à inserção do indivíduo no mercado de trabalho, arrisca-se a assumir a educação e, especificamente neste caso, a matemática simplesmente como uma "porta" para a mobilidade social. Consequentemente, uma vez que a própria lógica meritocrática cria "vencedores e perdedores", a matemática torna-se parte de um mecanismo de exclusão. 


\section{EDUCAÇÃO MATEMÁTICA: CONTRAPONTOS AO DISCURSO HEGEMÔNICO}

As discussões e análises desenvolvidas nos capítulos anteriores permitiram o esboço da função social do ensino de matemática, particularmente a partir da década de 1990. Uma vez que este esboço se construiu a partir de diferentes discursos identificados em marcos internacionais e na legislação nacional, ele representa a função social atribuída ao ensino de matemática pelo discurso hegemônico.

Trata-se de um discurso que se apropria da educação segundo as lógicas e interesses do neoliberalismo, personificados por organizações multilaterais como UNESCO, Banco Mundial e OCDE. Em última análise tais interesses sobre a educação representam estratégias para a própria sobrevivência e manutenção do liberalismo.

A apropriação dos discursos neoliberais sobre a educação, principalmente no caso dos países considerados periféricos segundo a ordem capitalista, já ocorria no âmbito das influências políticas e ideológicas, assim como na forma de empréstimos e investimentos focados na área educacional, como o caso dos acordos MEC/USAID firmados a partir de meados dos anos 1960. No entanto, é a partir das políticas de ajuste estrutural dos anos 1980 e 1990, que esta influência torna-se institucionalizada em nível global. Ou seja, o conjunto de condicionalidades estipuladas pelos ajustes aponta tanto para a apropriação econômica, uma vez que os programas e políticas públicas necessitam do financiamento de organizações como o Banco Mundial; quanto para a apropriação ideológica, uma vez que ao assumir esta dívida, os países também assumem a responsabilidade de alinhar seus currículos, propostas pedagógicas e, principalmente, as formas de gestão e distribuição dos recursos, com as orientações destas organizações. Em outras palavras, a consolidação do discurso 
hegemônico sobre a educação dos países periféricos não ocorreu necessariamente plano da influência, ou pela obtenção de um consenso, como se referiu Apple (2001), mas pela imposição. No entanto, isso não significa que tenha ocorrido por meio de coerção. $\mathrm{Na}$ verdade, existia uma própria demanda dos países periféricos em se inserir cada vez mais no projeto neoliberal.

Em uma esfera mais ampla, este discurso hegemônico é marcado pela lógica da eficiência e da produtividade, tanto na produção de indicadores e no acompanhamento dos resultados dos processos educacionais a partir de macro avaliações locais e internacionais (por exemplo, o Saeb e o PISA, respectivamente), quanto na gestão e alocação dos recursos em áreas consideradas prioritárias, partindo de uma concepção de justiça distributiva, associada à noção de equidade. São outros elementos deste discurso: a universalização do ensino entendida como igualdade de oportunidades, a correspondência entre a formação para a cidadania e a inserção no mercado de trabalho; a relação entre empregabilidade, escolaridade e mobilidade social; a política de garantias mínimas associada à satisfação das NEBA; a descentralização da gestão dos sistemas de educação, abrindo espaço para a inserção gradual do capital privado na educação pública, especialmente na figura de organizações não-governamentais.

Em outra esfera, o ensino de matemática é posicionado como responsável tanto por preparar o aluno para a cidadania e a sua inserção numa sociedade progressivamente mais pautada pela tecnologia, quanto, segundo Valero (2017), conferir aos alunos qualidades como racionalidade, objetividade, universalidade e subjetividade.

Este discurso representa uma série de problemas do ponto de vista do ensino: (i) ao postular a inclusão de todos, estabelece também 
uma norma que representa as expectativas da sociedade quanto ao aprendizado deste indivíduo, excluindo automaticamente aqueles que não se adequam à norma; (ii) ao considerar que a universalização do ensino básico segundo a lente da igualdade de oportunidades, legitima um jogo meritocrático constituído sobre uma falácia, no sentido que a igualdade de acesso ao sistema educacional não é garantia de igualdade de acesso à qualidade; (iii) sob a lente da equidade, os recursos, assim como as políticas públicas, precisam ser destinados aos setores sociais que mais necessitam, ou seja, para a escola pública, uma vez que tradicionalmente é a escola que recebe a população das classes com maiores necessidades sociais. Isso significa que, enquanto a rede particular goza de certa autonomia para o desenvolvimento de seus programas e currículos, a escola pública deve se alinhar a políticas como a (iv) política de limites mínimos e de satisfação das NEBA, que cria um currículo focado na aquisição de competências mínimas, mas segundo uma lógica da eficiência em termos de produção de mão de obra. De modo geral, ao mesmo tempo em que este discurso postula a inclusão, ele provoca a exclusão.

Em face deste problema, o presente capítulo se propõe a elencar e descrever algumas concepções e perspectivas de ensino de matemática com o potencial de promover uma inclusão de fato, que operem no sentido da redução das desigualdades sociais, que deem voz aos excluídos e "invisibilizados" pelo discurso hegemônico. Em outras palavras, são perspectivas que apresentam alternativas ao discurso hegemônico. No entanto, o objetivo do capítulo não é esgotalas, dada a própria complexidade e abrangência de cada uma, assim como da obra de seus principais nomes e autores, mas oferecer subsídios para se pesquisar e discutir o tema a partir de pontos de vista diversos que, em variadas instâncias, representam contrapontos a tal discurso hegemônico. 
Nesse sentido, desde meados dos anos 1980, porém mais preponderantemente nos anos 1990, as discussões sobre acesso à matemática e sobre o alegado poder que representa seu aprendizado para o indivíduo marcaram as discussões sobre algumas áreas da educação matemática (ENGLISH, 2002), especialmente vertentes que abordam a educação segundo uma perspectiva social, ou seja, que descentralizam a estrita preocupação pelo indivíduo para ampliar o grau de importância de questões como a cultura da sala de aula, formas de participação dos alunos, processos de socialização e novas formas de desenvolvimento profissional docente (GUTIÉRREZ, 2013).

$\mathrm{Na}$ educação matemática, a denominada virada social (LERMAN, 2000) se desenvolveu especialmente no fim dos anos 1980 , com base em disciplinas como antropologia, sociologia e psicologia cultural, no sentido de construir estruturas teóricas que interpretassem as origens sociais do conhecimento e da consciência, dando origem à teorias que veem o significado, o pensamento e o raciocínio como produtos da atividade social.

Segundo Lerman (2000), a influência do cognitivismo foi hegemônica nas teorias da aprendizagem nos anos 1960 e 1970, especialmente a partir da abordagem da epistemologia genética de Jean Piaget, criticando as concepções apriorísticas, empiristas e behavioristas do conhecimento (PIAGET, 1970, 1971; PIAGET E INHELDER, 1968).

A partir de meados dos anos 1970, segundo Lerman (2000), ganham espaço na pesquisa e nos discursos educacionais as discussões sobre o fracasso escolar baseadas na sociologia da diferença e nas teorias da reprodução e do déficit cultural (BOURDIEU, 1978, 1998 e 2003). No entanto, segundo Charlot (2000), algumas distorções decorrentes de interpretações destas perspectivas teóricas, 
resultaram na concepção de que a origem social é a causa do fracasso escolar.

Em contrapartida, segundo Lerman (2000), a partir dos anos 1980, verifica-se o reenquadramento do olhar da pesquisa educacional para uma abordagem histórico-cultural ofereceu possibilidades de ultrapassar a suposição de que as características dos grupos culturais estão localizadas dentro dos indivíduos - como portadores da cultura do grupo - imutáveis ao longo do tempo, independente do contexto e das ações do indivíduo (GUTIÉRREZ E ROGOFF, 2003). Tal "essencialização", ou seja, a tendência em reduzir um grupo a uma única (ou poucas) característica de modo a transmitir a essência desse grupo (GUTIÉRREZ, 2013), implica também na rotulação dos indivíduos com base nesta suposta essência (GUTIÉRREZ E ROGOFF, 2003), desconsiderando a diversidade que existe dentro dos próprios grupos e a subjetividade em suas relações.

Lerman (2000) analisa as principais ideias veiculadas no âmbito da pesquisa em educação matemática neste período, denominando este cenário como a virada para o social na educação matemática. Entre as principais ideias e perspectivas teóricas, Lerman (2000) destaca a concepção de aprendizagem situada (LAVE, 1988; LAVE E WENGER, 1991), que desafiou o cognitivismo e a teoria da transferência cultural na aprendizagem, posicionando a matemática como prática social; a partir da perspectiva da psicologia social, Carraher, Carraher e Schliemann (1988) analisaram as diferenças entre a matemática "das ruas" e matemática escolar, contrapondo a crença de que ser competente na matemática escolar é um indicador de inteligência; Walkerdine (1988) analisou a produção dos significados nas práticas e demonstrou como a própria noção de criança é o produto de uma prática discursiva; Bishop (1988) apresentou a concepção de enculturação matemática, a partir da qual a aprendizagem de um 
indivíduo é profundamente influenciada pela aprendizagem dos demais; D’Ambrósio (1984) apresentou a teoria da etnomatemática que, a exemplo de outras perspectivas, transferia a matemática para a esfera da prática social e, particularmente, propunha alternativas à visão eurocêntrica da matemática; por fim, considerou também a influência da concepção socio-construtivista de Vygotsky, especialmente nos trabalhos de Bruner (1986) e Wertsch (1981).

A produção deste novo conjunto de conhecimentos no campo da educação matemática - contrariando as teorias então hegemônicas propôs que elementos como significado, pensamento e raciocínio deixassem de ser objetos que emergem na mente de sujeitos cognitivos descontextualizados e passassem a ser constituídos no encontro de sujeitos contextualizados e historicamente fundamentados (VALERO, 2004).

As contribuições da educação crítica (FREIRE, 1998; MCLAREN, 2007; GIROUX, 1983; LADSON-BILLINGS, 1995) - assim como seus desdobramentos na educação matemática crítica (SKOVSMOSE, 1994, 2004; FRANKENSTEIN, 1987, 1998) - colocaram em foco a questão do poder e do caráter político da educação. Gutstein (2007) resume os objetivos pedagógicos da educação matemática crítica no sentido tanto do desenvolvimento de competências matemáticas, quanto da consciência crítica nos alunos. Mais ainda, tal perspectiva propõe que tais objetivos sejam dialeticamente interrogados de maneira consciente tanto por professores quanto por alunos. Assim, a matemática se constitui como um veículo para o aprofundamento da compreensão do indivíduo quanto ao contexto sociopolítico de suas próprias vidas e que estes, ao fazê-lo, fortalecem seu entendimento conceitual e procedimental da matemática. 
A inclusão destas discussões no âmbito da educação matemática, por sua vez, ampliou a virada social no sentido de uma virada sociopolítica. Gutiérrez (2013) posiciona tal virada na educação matemática como o movimento de entender os aspectos como conhecimento, poder e identidade a partir de discursos sociais, além de referenciar um crescente corpo de pesquisadores e professores que buscam destacar e se envolver nas tensões políticas concernentes à educação. Segundo Gutiérrez (2013, p.40), "adotar essa postura significa descobrir regras e formas de operação que garantem privilégios a alguns indivíduos e excluem outros".

Em seguida serão apresentadas algumas das perspectivas citadas: aprendizagem situada, etnomatemática e educação matemática crítica. O objetivo não é esgotá-las - mesmo porque seria impossível contemplar toda a sua produção, impactos e vicissitudes - mas analisálas no sentido de compreender como elas interrogam questões como poder, discurso, legitimação, equidade e justiça social.

\subsection{Aprendizagem situada}

As teorias situadas, consolidadas a partir do fim dos anos 1980 , principalmente por Jean Lave e Etienne Wenger (LAVE E WENGER, 1991; LAVE, 1988, 1996; WENGER, 1998) proporcionaram significados bastante diferentes às concepções de conhecimento e aprendizagem.

A partir de uma investigação etnográfica na Libéria nos anos 1970, Jean Lave analisou como os aprendizes de alfaiate aprendiam seu ofício (LAVE, 1988, 2015; LAVE E WENGER, 1991). Dessa investigação originaram profundos questionamentos sobre o processo de aprendizagem fora de uma perspectiva centrada na escola.

Lave (1996) concluiu que toda atividade é situada nas relações entre pessoas, contextos e práticas. A aprendizagem situada implica 
que o conhecimento está localizado em formas particulares de experiência situada, não simplesmente no conteúdo mental. Nesse sentido, Lerman (2000) considera que o conhecimento passa a ser então entendido de forma relacional.

Assim, a aprendizagem é situada em complexas comunidades de práticas. Wenger (1998) destaca três elementos fundamentais para distinguir uma comunidade de práticas de outros grupos ou comunidades: (i) o domínio: uma comunidade de prática é algo mais do que uma rede de conexões entre as pessoas. Tem uma identidade definida por um domínio compartilhado de interesse, o que implica um compromisso e uma competência partilhada que distingue os seus membros das "pessoas de fora"; (ii) a comunidade: os membros de seu domínio se envolvem em atividades e discussões conjuntas, ajudam uns aos outros e compartilham informações, constroem relacionamentos que thes permitam aprender conjuntamente; (iii) a prática: os membros de uma comunidade desenvolvem um repertório compartilhado de recursos, experiências, histórias, ferramentas, formas de lidar com problemas recorrentes, o que demanda tempo de contato e uma interação permanente com tal prática.

Em uma comunidade de práticas, a forma como as pessoas aprendem não é definida por pressupostos naturalizados sobre aquisição de conhecimentos. Ao mesmo tempo, a aprendizagem não ocorre paralelamente à prática, mas se configura como uma parte integrante de uma prática social. Nesse sentido, aprender é um processo no qual o indivíduo progressivamente se insere em uma comunidade de práticas. Este movimento, igualmente, se dá, em primeira instância, a partir da observação de seus limites, de suas fronteiras, ou, como uma "participação periférica legitimada" (WENGER, 1998). 
Além disso, a aprendizagem através da participação periférica legitimada ocorre independentemente da existência ou não de um contexto intencional de ensino (LAVE E WENGER, 1991).

Conforme a aprendizagem e a participação naquela comunidade se ampliam, o participante passa do papel de observador para o de agente pleno. É justamente a participação periférica legitimada que permite que o recém-chegado se aproprie progressivamente do repertório cultural do grupo até que passe a ser um membro da comunidade. Para ser capaz de participar dessa forma, os recémchegados precisam, no entanto, de amplo acesso a práticas plenamente estabelecidas e maduras (LAVE E WENGER, 1991).

Desse modo, a matemática pode ser entendida como uma prática social, já que o desenvolvimento de situações de modelagem matemática, do trabalho do matemático ou de um profissional que usa a matemática, também comporta mestres e aprendizes, assim como os procedimentos, linguagens e objetivos, como qualquer outra prática social (LERMAN, 2000).

Lave (1996) ressalta ainda que os conhecimentos formais e/ou escolares muitas vezes não são mobilizados tão facilmente para a solução de problemas práticos. As resoluções de problemas quantitativos, por exemplo,

Raramente chegam a respostas erradas, já que (as pessoas) tem uma noção clara do sentido das relações quantitativas que procuram e daquilo que será uma solução numérica em termos aproximados, mesmo porque, tendo também uma noção muito forte do significado do que estão a fazer, são capazes de por de lado os problemas que se reconhecem incapazes de resolver dentro do tempo e pelas razões disponíveis (LAVE, 1996, p.121). 
Nesse sentido, a partir da perspectiva da psicologia cultural, Schliemann (2006) comparou o desempenho de marceneiros que aprenderam a profissão de modo informal - como aprendizes de seus pais ou de outros mestres marceneiros - com estudantes de um curso formal de marcenaria. No estudo, foram propostos problemas práticos e as estratégias de resolução adotadas pelos dois grupos tornaram evidente a relação com o tipo de experiência de cada grupo.

Segundo Schliemann (2006), enquanto os marceneiros profissionais buscavam adequar suas peças a medidas padrão, encontradas no mercado, os estudantes tentavam medidas ideais; da mesma forma, os marceneiros profissionais buscavam sempre soluções viáveis, enquanto boa parte dos estudantes se detinha à solução obtida via geometria, por exemplo. No uso da aritmética, além de recorrer muito mais facilmente a aproximações e estimativas, os marceneiros profissionais utilizavam estratégias mais rápidas e econômicas de cálculo que os estudantes. O melhor desempenho dos marceneiros profissionais nesta situação pode ser justificado pelo fato de que o problema apresentado era naturalmente oriundo de sua comunidade de práticas. Apesar de ambas as comunidades (marceneiros profissionais e estudantes do curso marcenaria) possuírem um mesmo objeto de conhecimento (marcenaria), no que concerne às práticas, à linguagem, os procedimentos e os métodos as comunidades são bastante diferentes.

Supondo que alunos do curso de marcenaria já tivessem uma participação maior em uma comunidade de práticas de marceneiros profissionais, como ele lidaria com tais questões? De fato, independente de participar ou não de uma ou outra comunidade específica, os repertórios e as experiências pessoais de cada membro tornam a sua relação com a comunidade de práticas bastante particular. 
Nesse sentido, de modo a contemplar a questão da subjetividade, ou seja, da regulação dos indivíduos dentro das práticas (LERMAN, 2000; WALKERDINE, 1997), estas precisam ser entendidas como segundo à ótica do discurso (LERMAN, 2000; FOUCAULT, 1999, 2008). Nelas, são produzidas múltiplas e diferentes significações, uma vez que estão sujeitas não só às experiências particulares de cada indivíduo, como também as relações de poder que permeiam esta prática. Ressalta-se também que as práticas não podem ser delimitadas claramente, estando continuamente mudando de uma prática discursiva para outra através de cadeias de significação. Assim, os significados precisam ser constantemente renegociados a partir de uma série de situações.

Apesar da concepção de aprendizagem como participação periférica legitimada abrir novas possibilidades para a compreensão dos processos de ensino e aprendizagem, os seus desdobramentos para o âmbito da sala de aula precisam ser considerados com cautela. Segundo enfatizam Lave e Wenger (1991, p.40):

a participação periférica legitimada não é, por si só, uma forma educacional, muito menos uma estratégia pedagógica ou uma técnica de ensino. É um ponto de vista analítico sobre a aprendizagem, uma forma de compreender a aprendizagem.

Contudo, considerada como um ferramenta analítica, uma de suas principais contribuições é justamente a contraposição à teorias hegemônicas da aprendizagem, que a concebem como resultado da transmissão cultural, ou seja, aprender é um "desdobramento não problemático, um resultado, da transmissão ou da socialização" (LAVE, 2015, p.38). Coadunando esta concepção com pressupostos da psicologia cognitiva, a aprendizagem passa a ser concebida como um "desdobramento cognitivo do ensino, ou seja, como um resultado da 
missão da escola de realizar a transmissão cultural" (LAVE, 2015, p.38).

\subsection{Etnomatemática}

A etnomatemática passou a ser reconhecida internacionalmente após a conferência "Bases socioculturais para a educação matemática"12, proferida por Ubiratan D'Ambrosio no $5^{\text {th }}$ International Congress on Mathematics Education (ICME-5), ocorrido em Adelaide (Austrália) no ano de 1984. D’Ambrósio proferiu uma crítica ao que na época vinha sendo discutido como "solução de problemas", "matemática aplicada" ou "matemática utilitária", discutindo a concepção de matemática como sistema cultural, associado a noções como "história social da matemática" e "antropologia matemática" (KNIJNIK, 1996).

O fundamento da etnomatemática repousa na conscientização sobre as variadas maneiras de conhecer e de fazer matemática, relacionadas com os valores, ideias, noções, procedimentos e práticas em uma diversidade de contextos (ROSA E SHIRLEY, 2016). Ou ainda, nas várias maneiras, técnicas, habilidades de explicar, de entender, de lidar e de conviver com distintos contextos naturais e socioeconômicos da realidade (D'AMBROSIO, 2005). Com efeito, a disciplina a que denominamos por "matemática" é também uma "etnomatemática", porém desenvolvida no continente europeu, com algumas contribuições dos árabes e hindus chegando à forma atual ao longo dos séculos XVI e XVII (D'AMBROSIO, 2005).

A etnomatemática é referida por D'Ambrosio como um programa de pesquisa, no sentido do termo atribuído por Lakatos e Muskrave (1979), ou seja, caracterizado por um núcleo - a geração, organização e difusão do conhecimento - e pelo cinto de proteção a este núcleo -

12 Tradução própria para "Socio-cultural bases for mathematics education". 
todo aparato teórico e metodológico utilizado pelos pesquisadores (FERREIRA, 2007).

Segundo D’Ambrósio (2001, p. 17),

\begin{abstract}
Ao insistir na denominação Programa Etnomatemática, procuro evidenciar que não se trata de propor uma outra epistemologia, mas sim entender a aventura da espécie humana na busca de conhecimento e na adoção de comportamentos. (...) A pesquisa em etnomatemática deve ser feita com muito rigor, mas a subordinação desse rigor a uma linguagem e a uma metodologia padrão, mesmo tendo caráter interdisciplinar, pode ser deletério para o Programa Etnomatemática.
\end{abstract}

Desse modo, o programa etnomatemática pode ser abordado segundo uma série de dimensões inter-relacionadas (D'AMBRÓsIO, 2001; ROSA E OREY, 2016): (i) cognitiva, que diz respeito à aquisição, acumulação e disseminação do conhecimento matemático ao longo das gerações; (ii) conceitual, no sentido da elaboração de representações da realidade por grupos distintos; (iii) educacional, a partir da incorporação de valores humanos aos conhecimento de matemática tradicionalmente ensinados na escola; (iv) epistemológica, no sentido de refletir sobre a evolução do conhecimento matemático em relação às suas formas de criação, organização e disseminação; (v) histórica, a partir do estudo das correlações entre a história da matemática e a realidade dos alunos; (vi) política, no sentido de desenvolver ações políticas com vistas à formação de autonomia e da luta por direitos e da cidadania.

A pesquisa na área de etnomatemática é ampla, abordando desde as produções de fora do eixo ocidental-europeu e as formas de matemática dos povos nativos colonizados, até a matemática praticada no cotidiano por diversos grupos ou comunidades, assim como possibilidades e implicações para a matemática escolar (FERREIRA, 1994; BORBA, 1987, KNIJNIK, 1995, 1996; CARVALHO, 1991). Nesse 
sentido, as relações entre a etnomatemática e a aprendizagem situada não são coincidência, uma vez que compartilham de objetivos muito próximos. Da mesma forma, apesar de utilizar diferentes métodos e pressupostos teóricos, ambas as áreas também compartilham interesses comuns à psicologia cultural (ABREU, 2002; SCHLIEMANN, 2006; CARRAHER, 2006; CARRAHER E SCHLIEMANN, 2006).

A grande contribuição da etnomatemática para a educação matemática é o fato de ela possibilitar um olhar para a matemática não só como um produto social (a exemplo da aprendizagem situada), mas ao posicioná-la como produto cultural, reafirma e valida a produção e os modos de fazer matemática de diferentes povos e civilizações e, ao fazer isso, também assume o caráter político da matemática.

\subsection{Educação matemática crítica}

Partindo de um ponto de vista mais geral, Skovsmose (2001) salienta a teoria crítica e a Escola de Frankfurt (Theodor W. Adorno, Max Horkheimer, Herbert Marcuse, entre outros), assim como o marxismo, como grandes fontes de inspiração das então denominadas pedagogias críticas. Estas, segundo Gutstein (2007), assumem caráter decisivo para o desenvolvimento da educação matemática crítica, principalmente a partir dos trabalhos de Paulo Freire (FREIRE, 1968, 1978, 1979, 1985), Henry Giroux (GIROUX, 1983, 1988), Gloria LadsonBillings (LADSON-BILLINGS, 1995) e Peter McLaren (1989).

Nesse sentido, a seguir serão discutidos alguns elementos e conceitos-chave da educação matemática crítica à luz das pedagogias críticas, especialmente na perspectiva de Paulo Freire.

O pensamento freireano é profundamente político, uma vez que política, poder e educação se constituem para Paulo Freire num bloco indissociável (TORRES, 2003). Segundo Freire (1993, p.25), 
A compreensão dos limites da prática educativa demanda indiscutivelmente a claridade política dos educadores em relação a seu projeto. Demanda que o educador assuma a politicidade de sua prática. Não basta dizer que a educação é um ato político assim como não basta dizer que o ato político é também educativo. É preciso assumir realmente a politicidade da educação.

No âmbito da educação matemática crítica, a "politicidade" de Paulo Freire é abordada por Skovsmose (2001, p.38) segundo a perspectiva de um "engajamento crítico" de professores e alunos, no sentido de orientar o processo educativo para a resolução de problemas de "fora da sala de aula".

Tal compromisso político com a educação transborda sobre a concepção de conhecimento, ensino e aprendizagem de ambas as perspectivas críticas. Nesse sentido, a oposição às concepções positivistas de conhecimento na educação se estabeleceu como um dos principais pontos da epistemologia da pedagogia crítica (FRANKENSTEIN, 1983).

A concepção positivista de que o conhecimento é neutro, isento de valores e de existência independente da consciência humana, por suas próprias características o isentavam do aspecto político. Segundo Löwy (2010, p.39), a concepção positivista,

Afirma a necessidade e a possibilidade de uma ciência social completamente desligada de qualquer vínculo com as classes sociais, com as posições políticas, os valores morais, as ideologias, as utopias, as visões de mundo. Todo esse conjunto de elementos ideológicos, em seu sentido amplo, deve ser eliminado da ciência social. O positivismo geralmente designa esse conjunto de valores ou de opções ideológicas como prejuízos, preconceitos ou prenoções. A ideia fundamental do método positivista é de que a ciência só pode ser objetiva e verdadeira na medida em que eliminar totalmente qualquer interferência desses preconceitos ou prenoções. 
No caso da matemática, há uma dupla implicação da concepção positivista: dos elementos acima destacados - mais próximos do positivismo de Comte - deriva diretamente uma concepção de matemática ideal, próxima de uma perspectiva platônica, destituída das interferências humanas, valores e interesses inerentes ao seu processo de construção e desenvolvimento; do positivismo de, a matemática assume uma posição preponderantemente superior às demais ciências, segundo a qual a própria sociedade deveria ser organizada. Segundo Löwy (2010), para Condorcet, a precisão e o rigor da matemática seriam os únicos meios para a consolidação de uma ciência dos fatos sociais efetivamente objetiva, livres dos preconceitos das classes dominantes (clericais, absolutistas, dogmáticos etc.).

Tanto Paulo Freire quanto Henry Giroux se opunham a esta concepção (FRANKENSTEIN, 1983), uma vez que ela descarta questões como a construção social do conhecimento, os interesses e valores envolvidos na seleção, organização e avaliação dos dados e fatos, além de descartar a subjetividade e a dinamicidade do conhecimento.

Nesse sentido, a concepção de conhecimento proposta pela pedagogia crítica é a de um conhecimento dinâmico, produzido socialmente e estreitamente vinculado à consciência humana. Por sua dinamicidade e subjetividade, o conhecimento nunca pode ser dado como acabado, estando sempre sujeito a revisões. Uma das implicações diretas deste raciocínio é a própria condição do homem como ser inacabado ou inconcluso e que, por isso, se educa (FREIRE, 2003). Essa é uma condição fundamental para discutir algumas das relações de poder que envolvem a aquisição de conhecimentos e a educação, uma vez que, estando todos em uma mesma condição "inacabada", não há detentores supremos da razão e do conhecimento, 
da mesma forma que não existem ignorantes absolutos. A aprendizagem, então, deve se estabelecer dialogicamente:

\begin{abstract}
É através deste [do diálogo] que se opera a superação de que resulta um termo novo: não mais educador do educando, não mais educando do educador, mas educador-educando com educando-educador. Desta maneira, o educador já não é apenas o que educa, mas o que, enquanto educa, é educado, em diálogo com o educando que, ao ser educado, também educa. Ambos, assim, se tornam sujeitos do processo em que crescem juntos e em que os "argumentos de autoridade" já não valem (FREIRE, 2005, p.78-79).
\end{abstract}

Todavia, apesar de postular a não existência de sabedoria ou ignorância absoluta, é um fato que, especialmente em países de grandes desigualdades sociais, ou ainda, em sociedades opressivas com uma maioria dominada, a maioria possui uma consciência fragmentada de sua própria condição, sendo incapazes de pensar dialeticamente sobre ela, atribuindo a si mesmos as causas de sua condição (FRANKENSTEIN, 1983).

Desse modo, para que ocorra uma mudança social ou a libertação do oprimido, segundo uma concepção freireana, é necessário que haja um processo de conscientização dos indivíduos. Segundo Torres (2003, p.223),

A conscientização torna mais claro o caminho para uma compreensão crítica da situação de opressão e o modo de ultrapassá-la. Esta consciência crítica emerge num contexto específico de contradições sistêmicas e luta de classe, e, portanto, na radicalidade das classes populares.

A educação matemática crítica, por sua vez, interroga tais questões segundo a perspectiva do ensino e da aprendizagem em matemática, no sentido de compreender o seu papel no processo de tomada de consciência sugerido acima. Há também que se questionar como os seus usos cotidianos e perspectivas pedagógicas apoiam 
ideologias hegemônicas que impedem o indivíduo de atingir a consciência sobre sua condição (FRANKENSTEIN, 1983).

Outra preocupação da educação matemática crítica, compartilhada também pela pedagogia crítica, refere-se à democratização do conhecimento,

Isto é, preocupada com o fornecimento de acesso a ideias matemáticas para todos, independente de cor da pele, gênero e classe. Preocupa-se com o uso e a função de matemática na prática, sendo uma aplicação tecnológica avançada ou um usar. Preocupa-se com a vida em sala de aula, que deve representar um fórum democrático, onde ideias são apresentadas e negociadas (SKOVSMOSE E BORBA, 2004, p.207).

Skovsmose (2001) identifica dois tipos de argumentos acerca do relacionamento entre matemática e democracia. O argumento social, "tenta identificar um assunto relevante da educação matemática por meio de reflexões sobre possibilidades para a construção e o aperfeiçoamento de instituições democráticas e capacidades democráticas na sociedade, melhorando o conteúdo da educação" (SKOVSMOSE, 2001, p. 39). Este tipo de argumento se baseia em três premissas: (i) de que a matemática possui aplicações na sociedade e que, desse modo, (ii) tem a capacidade de formatar a sociedade e, finalmente, (iii) a partir do entendimento de tais aplicações, capacitar o indivíduo a exercer seus direitos e deveres (SKOVSMOSE, 2001).

O segundo argumento - o pedagógico - consiste em um olhar interno ao processo educacional. Skovsmose (2001) o considera a partir das premissas de que (i) existe uma lacuna entre o currículo oficial e aquilo que efetivamente é aprendido pelo aluno; (ii) que existe um currículo oculto da matemática que reitera, a partir da ideia de sucesso ou fracasso escolar, o seu próprio papel como meio de ascensão social; e que, como um próprio desdobramento desta premissa, (iii) considera a importância de salas de aula de matemática 
democráticas, como uma construção em nível micro para um exercício da democracia no âmbito social.

Todavia, segundo Skovsmose (2004), da mesma forma que a educação matemática pode "empoderar", ela também pode suprimir, uma vez que os papéis sócio-políticos da matemática não são fixos ou determinados, estando sujeitos às ideologias e à cultura dominantes.

Eu não relaciono a educação matemática com nenhuma posição otimista, alegando a existência de uma conexão intrínseca entre matemática, educação e, digamos, valores democráticos. Nem afirmo que a educação matemática por si só servirá interesses antidemocráticos. Em vez disso, simplesmente afirmo que nenhuma função da educação matemática representa tal essência.

Desse modo, a natureza crítica da educação matemática é incerta. Skovsmose (2004) pondera que reconhecer tal natureza é justamente uma das funções da educação matemática crítica. No entanto, a educação matemática crítica não deve ser concebida como uma metodologia, mas sim como um "conjunto de preocupações emergentes da natureza crítica da educação matemática", oriundas tanto da pesquisa quanto da prática.

Skovsmose (2001 e 2004) explicita algumas destas preocupações: (i) a "guetorização" (derivado da palavra "gueto") como um efeito da globalização, no sentido de que a matemática pode se configurar como elemento fundamental de ascensão e mobilidade social, resultando na exclusão daqueles que não são capazes de dominá-la; (ii) a concepção de que os progressos científico e social estão intimamente relacionados; (iii) a possibilidade de avaliar e decidir qual conhecimento é considerado válido, assim como as formas de ensiná-lo e aprendê-lo; (iv) a forma como os discursos no cotidiano 
articulam e conferem identidade à matemática; (v) concepções de educação matemática que provocam exclusão e discriminação.

\subsection{Educação matemática culturalmente relevante}

Gloria Ladson-Billings é considerada a precursora da denominada pedagogia culturalmente relevante. O seu desenvolvimento se deu como uma contraposição ao crescimento das disparidades observadas desde os anos 1980 entre as características raciais, étnicas e culturais de professores e alunos, especialmente entre as comunidades negras e latinas nos EUA (Ladson-Billings, 1995a, p. 483).

Nesse sentido, Ladson-Billings (1995b) a define como uma pedagogia da oposição, semelhante à pedagogia crítica, mas comprometida fundamentalmente com o "empoderamento coletivo", não apenas em termos individuais. Segundo esta concepção, para que uma pedagogia seja culturalmente relevante, os alunos como um todo precisam (i) adquirir experiências de sucesso acadêmico (escolar); (ii) desenvolver ou manter suas competências culturais; e (iii) desenvolver consciência crítica para desafiar o status quo da ordem social vigente (LADSON-BILLINGS, 1995b).

Estas três proposições se articulam na medida em que, a despeito das desigualdades sociais - ou como resposta a elas - todos os alunos precisam se alfabetizar, utilizar a matemática, as tecnologias, além desenvolver habilidades sociais e políticas para uma atuação democrática na sociedade, ao mesmo tempo em que faz uso, reforça e legitima as suas próprias referências culturais e, a partir delas, desenvolvem uma consciência crítica acerca de sua condição social (LADSON-BILLINGS, 1995b). Desse modo, um dos principais focos da pedagogia culturalmente relevante é desenvolver ambientes de aprendizagem onde os alunos são capazes de manter sua 
integridade cultural e, ao mesmo tempo, explorar as dinâmicas de poder para entender barreiras à acessibilidade da aprendizagem (GUTSTEIN, 2003, 2007).

Os argumentos por uma pedagogia da matemática culturalmente relevante indicam que esta deveria se basear no conhecimento cultural dos alunos, atreladas às suas experiências de vida (GUTIÉRREZ, 2002, 2013; GUTSTEIN, 2003, 2007). Desse modo, a sua identidade como aluno, as suas representações de matemática e o desenvolvimento de seu raciocínio matemático partiriam de seu contexto cultural. Segundo Freire (2003, p. 61), "nenhuma ação educativa pode prescindir de uma reflexão sobre o homem e de uma análise sobre suas condições culturais".

Gutstein (2003 e 2007) se apoia nas noções freireanas de conscientização (FREIRE, 2003, 2005) e de leitura do mundo (FREIRE E MACEDO, 2011) para propor alternativas efetivas para um ensino de matemática culturalmente relevante, a partir da articulação de três tipos de conhecimento (comunidade, crítico e clássico). O conhecimento da comunidade se situa no âmbito dos conhecimentos prévios que o aluno leva para dentro da escola, oriundos de suas experiências pessoais e do aprendizado informal, seja a partir de outras pessoas, familiares ou não, sejam de ambientes que frequenta, como o trabalho, cursos, internet, televisão, igreja, parques, biblioteca, ONGs etc. Os conhecimentos crítico e clássico correspondem à compreensão dos problemas e desafios encontrados na realidade social e ao conhecimento formal, aprendido na escola, respectivamente.

Todavia, segundo Gutstein (2007), os limites entre eles não são bem definidos, havendo invariavelmente a sobreposição dos três. Da mesma forma, a compreensão de sua realidade não assegura o 
conhecimento crítico, confundindo-se em muitos casos com o próprio conhecimento da comunidade. A realidade social precisa ser interrogada para que, desse modo, o conhecimento da comunidade possa se tornar crítico.

\subsection{Educação matemática realística}

A educação matemática realística foi desenvolvida pelo Instituto Freudenthal, na Holanda, deste a década de 1970, possuindo como base as ideias do matemático e educador Hans Freudenthal. A partir de suas observações sobre a forma como a matemática escolar era conduzida, especialmente a sua desvinculação com a realidade, ou seja, a matemática escolar se resumia a técnicas e algoritmos que pouco, ou nada, se relacionavam com utilizações práticas.

Segundo Gravemeijer e Terwel (2000), Freudenthal entendia a matemática como uma atividade humana, da mesma forma que o ponto de partida para o seu ensino não poderia se dar com base na transmissão de conhecimentos, mas como uma reinvenção. Nesse sentido, Freudenthal entendia que o ensino de matemática, especialmente para as crianças, deveria partir da "matematização da realidade".

As crianças pequenas não podem matematizar a matéria matemática, uma vez que, no início, não há matéria matemática que seja empiricamente real para elas. Além disso, matematizar os assuntos da realidade também familiariza os alunos com uma abordagem matemática das situações cotidianas. Podemos também nos referir aqui à atividade matemática de "procurar problemas", mencionada por Freudenthal, que implica uma atitude matemática que engloba o conhecimento das possibilidades e limitações de uma abordagem matemática, ou seja, saber quando uma abordagem 
matemática é apropriada e quando não é (GRAVEMEIJER, TERWEL, 2000, p. 782).

Desse modo, tal "matematização da realidade" poderia ocorrer tanto horizontalmente (no sentido do mundo para a matemática), quanto verticalmente (interna a própria matemática), sendo que tal diferenciação, na verdade, se estabeleceria a partir dos pontos de vista dos próprios atores (GRAVEMEIJER E TERWEL, 2000).

Nesse sentido, segundo Gravemeijer e Terwel (2000), a discussão em torno da educação matemática realística se baseia na necessidade de desenvolver uma pedagogia e uma didática que consiga integrar dois objetivos: entender a matemática como um processo, uma atividade humana; e obter, como produto deste processo, uma atividade genuinamente matemática. Uma possibilidade para tal se baseou na concepção de reinvenção guiada. Segundo (GRAVEMEIJER E TERWEL, 2000, p.788), "a ideia era permitir que os aprendizes considerassem o conhecimento que adquirissem como seu próprio conhecimento pessoal, conhecimento pelo qual eles mesmos são responsáveis". Além disso, este processo deveria ser experimentado pelo estudante como "matematização progressiva", ou seja, primeiramente, os estudantes devem começar por matematizar um determinado assunto da realidade para, em seguida, analisar a própria atividade matemática.

Nesse sentido, a educação matemática realística possibilita o rompimento com os discursos que posicionam a matemática segundo uma condição de intangibilidade ou distanciada de sua construção social. Proporciona-se, consequentemente, o desenvolvimento de contextos mais significativos para a aprendizagem da matemática, assim como compreender a interação social como parte deste processo. 


\section{CONSIDERAÇÕES FINAIS}

Abrimos esta tese compartilhando uma série de inquietações originadas em minha trajetória profissional como professor de matemática e educador social. Tais inquietações possuíam em grande parte uma raiz comum: os discursos ${ }^{13}$ sobre a educação e o ensino de matemática.

No entanto, a particularidade dos discursos que geraram tais inquietações remete ao fato de que deles emanam uma variedade de narrativas que incorporam dualidades ou paradoxos. É o caso de discursos que, por um lado se comprometem com um princípio de inclusão, mas que na prática se confirmam excludentes; ou que anunciam a defesa da igualdade, mas legitimam a desigualdade.

Em vista deste cenário assumimos como objetivo desta tese, não somente a identificação destes discursos, mas também a forma como são apropriados pelo ensino de matemática e se desdobram nos programas e propostas curriculares para a educação básica. Paralelamente, buscamos também compreender como os discursos sobre a identidade, função e status social da matemática influenciam e se fazem presentes nos próprios discursos sobre equidade.

Compõem esse tipo de discurso, enunciados como: "a noção de que as crianças devem ter acesso democrático à poderosas ideias matemáticas é um direito humano, e é importante para o futuro da nossa sociedade" (MALLOY, 2002, p.18).

13 O discurso é entendido nesta tese como um conjunto de enunciados e narrativas, faladas ou escritas. Trata-se de uma prática social, representa ideias, ações e significados sobre o mundo, assim como se insere num jogo de tensões, disputas e relações de poder que determinam sua produção, organização e redistribuição (Foucault, 2014 e 2008;

Fairclough, 2001; Valero, 2002; Pais, Stentoft, Valero, 2010). 
Esta afirmação contém elementos que apontam para princípios não só bem aceitos no discurso educacional, como também representando de uma série de bandeiras pelas quais lutar: "democracia", "direitos humanos", "acesso ao conhecimento" etc. No entanto, o que faz dela motivo de inquietação?

Com base em Valero (2002) e Gutiérrez (2013), verifica-se que as bandeiras e princípios citados giram em torno da noção de poder atribuída à matemática. Isso implica a atribuição de uma agência à matemática que ela própria não possui, personificando-a e separando-a de sua condição como criação humana. Além disso, ao propor a existência de um poder intrínseco, por um lado, a matemática pode ser entendida como um "árbitro da verdade", por outro, o indivíduo que a domina agrega para si a mesma condição. Nesse sentido, o paradoxo se apresenta, por exemplo, ao se questionar como se daria o "acesso democrático" a um conhecimento aparentemente intangível, alheio à criação humana? Ou ainda sendo ela objeto de disputa pelo poder, como garantir que, dada a existência de forças assimétricas nesta disputa, não ocorra a sua apropriação por somente uma parte destas forças, excluindo as demais?

Nesse sentido, enquanto parte da inquietação residia na constatação deste tipo de paradoxo em uma série de outros discursos e enunciados, outra parte remetia à aparente aceitação inequívoca destes discursos, circulando tanto ao nível do falatório (HEIDEGGER, 2005), como algo dito e repetido tantas vezes que torna-se naturalizado como verdade, esvaziando-se de significado e isento de críticas, quanto ao nível do senso comum, ou seja, como um conhecimento evidente, produzido nas interações cotidianas, que se renova em si mesmo, também refratário à críticas (SANTOS, 2010). 
Neste ínterim, os discursos que mais deflagraram inquietações foram aqueles que remetiam aos conceitos de igualdade e equidade, especialmente os veiculados por agências multilaterais como UNESCO, Banco Mundial e a OCDE. Tais discursos, por sua vez, se tornaram hegemônicos no âmbito da educação a partir da Declaração Mundial sobre Educação para Todos, assinada em 1990 na cidade de Jomtien (Tailândia). Este documento representou um marco histórico, inaugurando uma agenda internacional segundo o mote "educação para todos", capitaneada pela UNESCO, com apoio do Banco Mundial.

Assim, é importante recuperar as questões e hipóteses que orientaram esta tese: (i) os discursos que se formalizam nos marcos legais e documentos oficiais representariam o discurso hegemônico sobre a educação e o ensino de matemática? (ii) Uma vez que tais marcos e documentos geram programas sociais e políticas públicas, em que medida estes discursos se inserem na lógica cotidiana da escola e influenciam o próprio discurso educacional? (iii) Entendendo como os discursos são produzidos e ressignificados a partir de todo um espectro de concepções, intenções, interesses, justificativas e disputas, ao menos parcialmente, o discurso hegemônico também seria construído no (e pelo) próprio cotidiano escolar? Nas considerações a seguir, procuraremos retomar as discussões realizadas ao longo dos capítulos no sentido de responder tais questões.

A Declaração de Jomtien, tal qual nos referimos ao longo desta tese, representou não somente o marco inicial para a internacionalização de políticas públicas na educação, como também sintetizou o discurso neoliberal nas propostas educacionais direcionadas principalmente aos países periféricos do capitalismo. Da mesma forma, demarcou a posição proeminente do Banco Mundial e da UNESCO como referências mundiais em educação, orientando pedagogicamente as ações dos países, desenvolvendo materiais 
didáticos, propondo avaliações em larga escala para acompanhar os resultados, segundo a lógica da eficiência, e direcionando a forma como os países gerenciam e distribuem seus recursos.

A partir da agenda internacional sobre "educação para todos", o discurso da equidade passou a se figurar de forma mais preponderante nas políticas e discursos educacionais. Uma preocupação suscitada ao longo da tese é como tais discursos, ao postular e defender princípios de igualdade e equidade, podem ocasionar a desigualdade. Assim, com base em Abbagnano (2007) e Bobbio, Matteucci e Pasquino (1998), foram discutidas as principais concepções de igualdade produzidas ao longo da história, bem como critérios para que uma distribuição de benefícios, ou de ônus, pudesse ser considerada igualitária. Neste contexto, a concepção de equidade surge como aspecto de justiça nos critérios de distribuição ao reposiciona-los das concepções de "tudo para todos" ou de "partes iguais para todos", para "partes proporcionais de acordo com as necessidades" ou, numa formulação segundo a qual - próprio Estado Moderno se consolidou a partir da Revolução Francesa e da Independência dos EUA, "partes proporcionais de acordo com o mérito".

Nesse sentido, de modo a compreender como a educação se apropria, e é apropriada, pelos discursos sobre igualdade e equidade, consideramos ao longo do texto o próprio processo de consolidação do projeto de escola pública nos séculos XVIII e XIX. Historicamente, tais discursos se compuseram de uma série de narrativas de salvação e redenção, de valorização das liberdades individuais, de princípios de igualdade, cidadania e aquisição de direitos civis, amparados segundo ideais liberais, burgueses e republicanos.

A principal narrativa, na qual educação e igualdade se vinculam, se situa no sentido de que, ao romper com as relações sociais 
herdadas do feudalismo e do absolutismo, especialmente quanto à determinação da posição social "por nascimento", o então cidadão republicano, fazendo uso de suas liberdades, poderia almejar e ascender socialmente livremente, sendo os únicos obstáculos para tal seriam suas próprias limitações de talento ou mérito. A universalização da educação se inseriu dessa forma, como instrumento para a equalização das oportunidades, ou seja, ao menos em teoria, todo cidadão poderia tomar parte do jogo meritocrático a partir das mesmas condições.

Desse modo, recuperamos as considerações feitas por Dubet (2004), no sentido de que a consolidação da escola pública não tornou a sociedade mais justa porque reduziu as diferenças sociais, mas porque permitiu a todos os indivíduos, sobre o princípio da igualdade de oportunidades, participar do jogo meritocrático.

A matemática, por sua vez, assumiu na consolidação da escola pública burguesa, um papel fundamental no cotidiano escolar, tanto por ser considerada fundamental para o progresso das ciências e da indústria (ROQUE, 2012; GOMES, 2008), quanto pelo seu peso na seleção de candidatos às universidades europeias, como o caso da École Polytechnique (ROQUE, 2012; SILVA, 2013). Tal discurso sobre a importância da matemática para o progresso se renovou ano após ano, seja no modelo de estado desenvolvimentista, seja sob a perspectiva do tecnicismo, seja em sua associação com a computação e a informática a partir dos anos 1980 .

Entretanto, a concepção de equidade adotada pelo discurso hegemônico neoliberal, presente nos documentos e propostas políticas para a educação das agências multilaterais, se aproxima da reinterpretação desta concepção realizada por John Rawls nos anos 1970. De modo geral, esta reinterpretação agregou à noção de 
equidade o princípio da diferença (RAWLS, 2000), segundo o qual o Estado, por meio de políticas públicas, deveria garantir que bens primários como educação, saúde etc. fossem distribuídos sempre a partir das necessidades dos "menos favorecidos". No entanto, a partir do princípio de igual distribuição das liberdades, Rawls (2000) também cria condições para que os "mais favorecidos" possam acumular bens materiais e sociais que os diferenciem ainda mais dos demais. No entanto, segundo a perspectiva de Rawls (2000), tal diferença não deixaria de ser benéfica também aos menos favorecidos, no sentido de que, a partir de políticas, por exemplo, de tributação progressiva, parte dos recursos acumulados pelos mais favorecidos seria redistribuída, via políticas públicas, aos menos favorecidos.

Assim, dado que sob a lente da equidade, as políticas públicas precisam ser destinadas primariamente aos setores sociais que apresentem maiores necessidades, no âmbito da educação brasileira isso significou que tais políticas deveriam focalizar a escola pública, uma vez que, tradicionalmente, é espaço de acolhimento das classes com maiores necessidades sociais. Desse modo, se por um lado é a escola pública a grande beneficiária dos empréstimos realizados por agências internacionais, como o Banco Mundial, é também sobre ela que incidirão as normativas e exigências destas agências. Esse alinhamento com os discursos neoliberais, veiculados pelas agências multilaterais e presentes por toda a agenda de políticas sobre "educação para todos", foi traduzido na escola pública como a garantia de limites mínimos de aprendizagem ou a satisfação das necessidades básicas de aprendizagem que, a partir da lógica da eficiência e da formação para o mercado de trabalho, garantiam uma mão de obra minimamente qualificada. Isso, de certa forma, referendado pelo próprio Banco Mundial, como pode ser constatado no relatório publicado em 1990 sob o título "A pobreza": 
(...) observa-se que o meio mais eficaz de obter avanços rápidos e politicamente sustentáveis na qualidade de vida dos pobres, (...) é a busca de um modelo de crescimento que garanta o uso produtivo do bem mais abundante entre os pobres - o trabalho (BANCO MUNDIAL, 1990, p.iii, grifo nosso).

A este contexto soma-se o fato de que, por sua obrigatoriedade, a escola pública também goza de uma posição privilegiada dentre os órgãos do Estado para acessar a população mais pobre, permitindo que gradualmente, também passasse a centralizar ações e políticas compensatórias; condição esta garantida pela própria Lei de Diretrizes e Bases da Educação Nacional, de 1996:

Atendimento ao educando, no ensino fundamental público, por meio de programas suplementares de material didático-escolar, transporte, alimentação e assistência à saúde (BRASIL, 2005, artigo 4).

Nesse sentido, segundo Graciani (2015, p.66),

A escola pública brasileira foi utilizada como centralizadora de uma série de iniciativas que associou o direito humano à Educação e com a afirmação dos direitos humanos de crianças, adolescentes e jovens, tornando-se então, o eixo propulsor de direitos civis e sociais que não foram possíveis de serem assegurados, por exemplo, na família.

Neste ponto, gostaríamos de retomar o objetivo principal estabelecido para esta tese: "identificação de como os discursos sobre igualdade e equidade, presentes nas normativas internacionais propostas por organizações multilaterais como UNESCO, OCDE e Banco Mundial, são apropriados pelo ensino de matemática e se desdobram nos programas e propostas curriculares para a educação básica. Da mesma forma, buscamos compreender como os discursos sobre a identidade, função e status social da matemática influenciam e 
se fazem presentes nos próprios discursos sobre equidade" ${ }^{14}$.

Nesse sentido, a partir da análise dos documentos produzidos pela UNESCO, ressaltando a Declaração Mundial sobre Educação para Todos (1990) e a Declaração de Nova Delhi sobre Educação para Todos (1993); e também de documentos legais nacionais, como Plano Decenal de Educação para Todos (1993), a Lei de Diretrizes e Bases da Educação Nacional (1996) os Parâmetros Curriculares Nacionais (1997 e 1998), foi possível constatar que:

i. O contexto político, econômico e social do neoliberalismo, no qual estava inserida a produção dos documentos citados, representado na ordem dos discursos, torna-se explícito principalmente nas Declarações de Jomtien e Nova Delhi. Devido à própria ideia de "declarar" algo, ou seja, revelar uma intenção, tornar público um determinado posicionamento. Este, por sua vez, é carregado de discursos que compõem a sua identidade ideológica. Ou seja, a própria constituição do texto das Declarações agrega tais discursos de um modo quase natural. Entretanto, é fundamental entender que ao declarar seu posicionamento, organizações como UNESCO e Banco Mundial, estão intencionalmente instituindo discursos e concepções, como equidade, justiça e as funções da educação, em nível global. Ou seja, dada a sua própria autoridade tais organizações legitimaram internacionalmente tais discursos, os oficializaram e materializaram segundo estas Declarações.

ii. Seja como demonstração de afinidade ou afiliação com o discurso neoliberal, seja como condição obrigatória a partir da política de ajustes estruturais, as políticas públicas e a legislação educacional brasileira na década de 1990 reestruturaram o ensino

14 Ver Apresentação. 
segundo os discursos expressados nas Declarações de Jomtien e Nova Delhi. Da análise do texto dos documentos é possível verificar vários momentos de intertextualidade, recuperando e reiterando as Declarações, e também, como uma marca mais constante a interdiscursividade. Esta se manifesta nos textos da legislação nacional, por meio de termos e conceitos como "igualdade de oportunidades", "valorização das diferenças", "satisfação de necessidades básicas", "programas suplementares", "parcerias com setor privado" etc.

iii. Uma vez que o foco destas Declarações se fixou na "satisfação de necessidades básicas de aprendizagem" e no âmbito mais geral da universalização do acesso à educação, as referências ao ensino de matemática se resumiram à indicações sobre o aprendizado das operações fundamentais. A análise dos PCN tanto para $\circ 1^{\circ}$ e $2^{\circ}$ ciclos quanto para $\circ 3^{\circ}$ e $4^{\circ}$ ciclos, demonstrou que, em termos de conteúdo, pouco foi acrescentado ou subtraído. De fato, segundo Godoy e Santos (2012, p.274), "os conhecimentos e saberes matemáticos, eles pouco, ou quase nada, sofreram alterações ao longo do século $X X$, no que tange aos documentos curriculares". Nesse sentido, um dos principais destaques dos PCN é o posicionamento da matemática segundo a função de formar para a cidadania, segundo um discurso de inserção no mercado de trabalho e da preparação para a participação em uma sociedade cada vez mais permeada pela tecnologia, a informática e a computação. É a partir desta linha de raciocínio que o eixo Tratamento da Informação ganha importância nos currículos, principalmente quando utilizado em associação com os Temas Transversais, seja na obtenção, organização, e interpretação de informações, seja na produção de argumentos para orientar e fundamentar as conclusões. 
A análise dos documentos possibilitou avaliar como o ensino de matemática, se insere no discurso hegemônico, principalmente ao reforçar elementos como formação para cidadania e a formação para o mundo do trabalho, ambos, por sua vez, possuindo como contexto de fundo, a necessidade de adaptação às demandas de uma sociedade cada vez mais caracterizada pelas tecnologias da informação e globalizada. Nesse sentido, segundo Skovsmose e Valero (2002, p.401), "a educação matemática poderia ajudar a garantir o acesso a sociedade informacional, bem como estabelecer e legitimar sua exclusão".

Finalmente, à luz das discussões apresentadas nos capítulos que compõem esta tese, propomos a reflexão no que se referem às inquietações a que nos referimos no início da tese, originadas essencialmente da aparente dubiedade a que estão sujeitos os discursos sobre equidade no âmbito da educação. No entanto, quando dito desta forma, fica subentendido que o problema reside na interpretação sobre tais discursos. Assim, atores e movimentos sociais, ao empunharem bandeiras como igualdade de acesso à educação, inclusão, diversidade, ou da defesa de ações afirmativas, estão, na verdade, iludidos segundo uma interpretação que, na prática, terá efeitos potencialmente inversos. Desse modo, é mais pertinente o entendimento desse cenário no sentido da existência de uma apropriação perversa destes discursos por parte do discurso hegemônico, segundo Dagnino (2004).

Enquanto, por um lado, os maiores interessados na defesa da equidade são aqueles que se encontram em uma condição na qual o acesso a determinados benefícios é concedido de forma desigual; por outro, existem aqueles que não se encontram nesta condição, mas que defendem a mesma bandeira da equidade, seja por estarem sujeitos a reflexos negativos da desigualdade, seja por contemplarem nesta 
defesa formas de agregar para si outros benefícios. Em outras palavras, existiria uma identidade de propósitos, sobre a defesa da equidade.

Este é o caso, por exemplo, da discussão em torno da concepção de diversidade e diferença no âmbito da educação. Se por um lado passaram a incorporar os discursos sobre igualdade, por outro, a forma como tais noções são veiculadas nestes discursos podem incorrer em uma série de "ciladas" (CANDAU, LEITE, 2011, ABRAMOWICZ, RODRIGUES, CRUZ, 2011).

\begin{abstract}
A narrativa da nação diversa, de um povo diverso, gera materiais didáticos no campo da educação e não sabemos mais se falamos de raça ou de cultura ou de desigualdade social, ou de diferença. Assim ficamos em um campo nebuloso onde se obscurecem as diferenças, e também as desigualdades. De maneira que esta espécie de outro onde foram colocados e excluídos os diferentes, os racializados, colocados no lugar da doença e/ou do desvio e tratados como inexistentes, incivilizados, bárbaros, estranhos são de alguma maneira recapturados por uma rede denominada diversidade, e incorporados, ou melhor, incluídos, de forma que a diferença que anunciam não faça nenhuma diferença (ABRAMOWICZ, RODRIGUES E CRUZ, 2011, p.93).
\end{abstract}

Nesse sentido, Abramowicz, Rodrigues e Cruz (2011) pontuam como os discursos sobre diferença e diversidade podem ser considerados através de ópticas distintas: a primeira é que geram contradições, porém passíveis de serem apaziguadas a partir da máxima da tolerância; a segunda, é que existem diferenças que geram diferenças e que, por não se tratar de uma contradição, não podem ser apaziguadas; por fim, a sua apropriação pelo discurso neoliberal ao conceber a diferença e a diversidade como estratégia para a ampliação das fronteiras do próprio mercado.

É a esta última concepção a que nos referimos, com base em Dagnino (2014), como apropriação perversa do discurso. Mais 
especificamente, no caso delineado nesta tese, a apropriação perversa do discurso de equidade na educação pelo neoliberalismo. Da mesma forma que no exemplo da diversidade, o que se opera no caso da equidade na educação é tanto o esvaziamento de seus sentidos políticos e sociais quanto a sua apropriação pelo discurso hegemônico do neoliberalismo. Nesse sentido, ressaltamos que ambos os movimentos - de esvaziamento e apropriação - não ocorrem de forma independente, uma vez que o próprio esvaziamento dos discursos facilita a sua apropriação. As interpretações dúbias ao qual nos referimos inicialmente nada mais são que deslocamentos de sentido nos discursos, são instrumentos para que tal apropriação ocorra.

Finalmente, apresentamos concepções ou perspectivas teóricas que inspiram possibilidades de um ensino de matemática que não somente apresente alternativas ao discurso hegemônico, mas que também possua o potencial de ressignificar a própria noção de matemática para todos. As perspectivas em educação matemática orientadas segundo um eixo social e sociopolítico, conforme apresentadas no texto, representam uma base importante para este movimento, no sentido de romper com a aparente idealidade a que a matemática está sujeita e posiciona-la como prática social, produzida por sujeitos situados num determinado contexto histórico e cultural; de compreender o contexto das relações de poder e disputas em que o ensino de matemática está inserido; e de, dessa forma, dissolver problemas que implicam ou legitimam a exclusão. 


\section{REFERÊNCIAS}

ABBAGNANO, Nicola. Dicionário de filosofia. 5 ed. Tradução de Alfredo Bosi. São Paulo: Martins Fontes, 2007.

ABRAMOWICZ, Anete; RODRIGUES, Tatiane C.; CRUZ, Ana Cristina J. da. A diferença e a diversidade na educação. Contemporânea. São Carlos, n.2, p. 85-97, jul./dez., 2011.

ABREU, Guida de. Mathematics learning in out-of-school contexts: a cultural psychology perspective. In: ENGLISH, Lyn D. Handbook of International Research in Mathematics Education. New Jersey: Lawrence Earlbaum Associates, 2002.

APPLE, Michael W. Política cultural e educação. Tradução de Maria José do Amaral Ferreira. 2 ed. São Paulo: Cortez, 2001.

ALTICK, Richard Daniel. The english common reader: a social history of the mass reading public (1800-1900). Columbus: Ohio State University Press, 1998.

ARAÚJO, Gilda Cardoso de. Estado, política educacional e direito à educação no Brasil: O problema maior é o de estudar. In: Educar em Revista, Curitiba, Brasil, n. 39, p. 279-292, jan./abr. 2011. Editora UFPR.

ARENDT, Hannah. A condição humana. 10. ed. Rio de Janeiro: Forense Universitária, 2007.

ARON, Raymond. Dezoito lições sobre a sociedade industrial. Tradução de Sérgio Bath. São Paulo: Martins Fontes, 1981.

AZANHA, José Mário Pires. Educação: temas polêmicos. São Paulo: Martins Fontes, 1995.

BANCO MUNDIAL. Relatório sobre o desenvolvimento mundial 1990: a pobreza. São Paulo: FGV, 1990.

BENAVOT, Aaron. Curricular Content, Educational Expansion, and Economic Growth. Washington, DC: PRE Dissemination Center, 1991. 
A global study of intended instructional time and official school curricula, 1980-2000. Genebra: IBE/UNESCO, 2004.

BICUDO, Maria Aparecida Viggiani. Pesquisa qualitativa e pesquisa qualitativa segundo a abordagem fenomenológica. In: BORBA, Marcelo de Carvalho; ARAÚJO, Jussara de Loiola (orgs.). Pesquisa qualitativa em educação matemática. Belo Horizonte: Autêntica, 2006.

BOBBIO, Norberto; MATTEUCCI, Nicola; PASQUINO, Gianfranco. Dicionário de política. Vol.1., ed. 11. Tradução de Carmem C. Varriale, Gaetano Lo Mônaco, João Ferreira, Luís Guerreiro Pinto Cacais e Renzo Dini. Brasília: Editora UnB, 1998.

BOLTANSKI, Luc. Sociologia da crítica, instituições e o novo modo de dominação gestionária. Tradução de Philippe Dietman Sociologia \& Antropologia, Rio de Janeiro, v.3, n.6, p.441-463, nov./2013.

BOLTANSKI, Luc; CHIAPELLO, Ėve. O novo espírito de capitalismo. Tradução de Ivone C. Benedetti. São Paulo: Martins Fontes, 2009.

BOLTANSKI, LUc; THÉVENOT, Laurent. The sociology of critical capacity. European Journal of Social Theory. Londres, v. 2, n. 3, p. 359-377, 1999.

BORBA, Marcelo de Carvalho. A pesquisa qualitativa em educação matemática. In: Reunião Anual da Anped, 27, 2004, Caxambu. Anais.

BOTO, Carlota. Na Revolução Francesa, os princípios democráticos da escola pública, laica e gratuita: o relatório de Condorcet. In: Educação e sociedade. V. 24, n. 84, p. 735-762, setembro, 2003. Disponível em $<$ http://www.cedes.unicamp.br $>$ Acessado em 01/05/2018.

BRIZUELA, Bárbara M. CARRAHER, David W. SCHLIEMANN, Analúcia $D$. El carácter algebraico de la aritmética. De las ideas de los niños a las atividades en el aula. Buenos Aires: Paidós, 2011.

BRUNER Jerome. Actual minds, possible worlds. Cambridge: Harvard University Press, 1986.

BRASIL. Constituição, 1988. Constituição: República Federativa do Brasil. Brasília: Senado Federal, 1988. 
BRASIL. Plano decenal de educação para todos. Brasília: MEC, 1993.

BRASIL. Parâmetros curriculares nacionais: matemática. Brasília: MEC/SEF, 1997.

BRASIL. Parâmetros curriculares nacionais. Terceiro e quarto ciclos do ensino fundamental: matemática. Brasília: MEC/SEF, 1998.

BRASIL. Lei de diretrizes e bases da educação nacional. Brasília: Edições Câmara, 2006.

CANDAU, Vera Maria; LEITE, Mirian Soares. Diferença e desigualdade: dilemas docentes no ensino fundamental. Cadernos de Pesquisa. São Paulo, v. 41, n. 144, p. 948-967, set./dez., 2011.

CAREgnATO, Rita Catalina A.; MUTTI, Regina. Pesquisa qualitativa: análise de discurso versus análise de conteúdo. Texto e Contexto Enfermagem, Florianópolis, v.4, n.15, p. 679-684, out./dez., 2006.

CARRAHER, Terezinha; CARRAHER, David; SCHLIEMANN, Analúcia. $\mathrm{Na}$ vida dez, na escola zero. $14^{\mathrm{a}}$ ed. (2006). São Paulo: Cortez, 1988.

CASTELLS, Manuel. A Sociedade em Rede. 2 ed.Tradução de Roneide Venâncio Majer. São Paulo: Paz e Terra, 2005.

CATTANEI, Elisabetta. Entes matemáticos e metafísica. Platão, a Academia e Aristóteles em confronto. São Paulo: Loyola, 2005.

CEFAÏ, Daniel. Como nos mobilizamos? A contribuição de uma abordagem pragmatista para a sociologia da ação coletiva. Dilemas: Revista de Estudos de Conflito e Controle Social, Rio de Janeiro, v. 2, n. 4, p. 11-48, abr./maio/jun., 2009.

CHARLOT, Bernard. Da relação com o saber. Porto Alegre: Artmed, 2000.

A mistificação pedagógica. Realidades sociais e processos ideológicos na teoria da educação. Tradução de Maria José do Amaral Ferreira. São Paulo: Cortez, 2013 a.

educativas. São Paulo: Cortez, 2013 b. 
CHIAPPIN, José Raymundo N.; LEISTER, Carolina. New Origin for the Law, Politics and Economics of Institutions: Classical Contractualism and Utilitarianism Programs of the Emergence of Cooperation and their Social and Political Technologies. The institutions of the State, of the corporation and of the market for the construction of the Nation-state. 2017. No prelo.

CORAGGIO, José Luís. Desenvolvimento humano e educação. 3.ed.São Paulo: Cortez, 2000.

CRUICKSHANCK, Marjorie. Factory children and compulsory education: the short-time system in the textile areas of north-west England (183364). In: The vocational aspect of education. V. 30, n. 77, p. 111-117, 1978. Disponível em: <https://doi.org/10.1080/10408347308001101>. Acessado em 22/12/2017.

DAGNINO, Evelina. ¿Sociedade civil, participação e cidadania: de que estamos falando? In: MATO, Daniel (org.). Políticas de ciudadanía y sociedad civil en tiempos de globalización. p. 95-110. Caracas: FACES, 2004.

D’AMORE, Bruno. Epistemologia e didática da matemática. São Paulo: Escrituras, 2005.

D'AMBROSIO, Ubiratan. Socio-cultural bases for mathematical education. In: Proceedings of the Fifth International Congress on Mathematical Education. Boston: Birkhäuser, 1984.

Sociedade, cultura, matemática e seu ensino In: Educação e Pesquisa, São Paulo, v. 31, n. 1, p. 99-120, jan./abr. 2005

Etnomatemática. Elo entre tradições e modernidade. Belo Horizonte: Autêntica, 2005.

DAMEROW, Peter et al. (ed.). Mathematics for all: problems of cultural selectivity and unequal distribution of mathematical education and future perspectives on mathematics teaching for the majority. Report and papers presented in theme group I, 'Mathematics for All' at the 5th International Congress on Mathematical Education, Adelaide, August 24-29, 1984. UNESCO, 1984. 
DARDOT, Pierre; LAVAL, Christian. A nova razão do mundo: ensaio sobre a sociedade neoliberal. Tradução de Mariana Echalar. São Paulo: Boitempo, 2016.

DUARTE, André. Heidegger e a linguagem: do acolhimento do ser ao acolhimento do outro. Curitiba: UFPR, 2007.

DUBET, François. O que é uma escola justa? Tradução de Édi Gonçalves de Oliveira e Sérgio Cataldi. Cadernos de Pesquisa, São Paulo, v.34, n.123, p. 539-555, set./dez. 2004.

DUFFY, Brendan. The analysis of documentary evidence. In: BELL, Judith. Doing your research project. A guide for first-time researches in education, health and social science. 4 ed. Nova Iorque: Open University Press, 2005.

DURU-BELLAT, Marie. Amplitude e aspectos peculiares das desigualdades sociais na escola francesa. In: Educação e Pesquisa, São Paulo, v. 31, n. 1, p. 13-30, jan./abr. 2005.

ENGLISH, Lyn D. Priority Themes and Issues in International Research in Mathematics Education. In: ENGLISH, Lyn D. 3rd Handbook of International Research in Mathematics Education. p.3-15 New Jersey: Lawrence Earlbaum Associates, 2002.

EVES, Howard. Introdução à história da matemática. Campinas: Ed. UNICAMP, 2004.

FREUDENTHAL, Hans. Mathematics as an educational task. Dordrecht: D. Reidel Publishing Company, 1973.

. Didactical phenomenology of mathematical structures. Nova York: Kluwer Academics, 2002.

FAIRCLOUGH, Norman. Discurso e mudança social. Brasília: Editora UnB, 2001.

Análise crítica do discurso como método em pesquisa social científica. Tradução de Iran Ferreira de Melo. Linha d'Água, São Paulo, v.2, n.25, p. 307-329, 2012.

FOUCAULT, Michel. A arqueologia do saber. 7 ed. Rio de Janeiro: Forense Universitária, 2008. 
A ordem do discurso. Tradução de Laura Fraga de Almeida Sampaio. 24 ed. São Paulo: Loyola, 2014.

Ditos e escritos IV: estratégia, poder-saber. 2 ed. Rio de Janeiro: Forense Universitária, 2010.

GALLO, Silvio. A escola pública numa perspectiva anarquista. Verve, São Paulo, n.1, 2002.

GATES, Peter; VISTRO-YU, Catherine P. Is mathematics for all? In: BISHOP, Alan J.; KEITEL, Christine; CLEMENTS, M.A.; LEUNG, Frederick K.S. Second International Handbook of Mathematics Education. p. 31-73. Nova York: Kluwer Academic Publishers, 2003.

GERRARD, Steve. Wittgenstein's philosophies of mathematics. In.: Synthese. Vol. 87. Nova York: Kluwer Academic Publishers, 1991.

Wittgenstein in transition: the philosophy of mathematics. Chicago: The University of Chicago, 1987. (tese de doutorado).

GIDDENS, Anthony. Mundo em descontrole. 6 ed. Rio de Janeiro: Record, 2007.

GIROUX, Henry. Theory and Resistance in Education. London: BergineGarvey, 2001.

GLOCK, Hans-Johann. Dicionário Wittgenstein. Rio de Janeiro: Zahar, 1998.

GODOY, Elenilton Vieira; SANTOS, Vinício de Macedo. O cenário do ensino de matemática e o debate sobre o currículo de matemática. Práxis Educacional, Vitória da Conquista, v.8, n.13, p.253-280, jul./dez. 2012.

GOFFMAN, Erving. A representação do eu na vida cotidiana. Petrópolis: Vozes, 1975.

GOLDIN, Gerald. Representation in mathematical learning and problem solving. In: ENGLISH, Lyn D. Handbook of International Research in Mathematics Education. New Jersey: Lawrence Earlbaum Associates, 2002. 
GOMES, Maria Laura Magalhães. Quatro visões iluministas sobre a educação matemática:Diderot, D'Alembert, Condillac e Condorcet. Campinas: Editora UNICAMP, 2008.

GORZ, André. O imaterial: conhecimento, valor e capital. Tradução de Celso Azzan Jr. São Paulo: Annablume, 2005.

GOTTSCHALK, Cristiane. A Natureza do Conhecimento Matemático sob a Perspectiva de Wittgenstein: algumas implicações educacionais. Cadernos de História Filosofia e Ciências, série 3, v. 14, n. 2, p. 305-334, jul.-dez. Campinas, 2004.

A construção e transmissão do conhecimento matemático sob uma perspectiva wittgensteiniana. Caderno Cedes, Campinas, v. 28, n. 74, p. 75-96, jan./abr., 2008.

GRACIANI, G.D. A função social da escola pública brasileira: um estudo exploratório. São Paulo: Universidade de São Paulo, 2015. (tese de doutorado).

GRAVEMEIJER, Koeno; TERWEL, Jan. Hans Freudenthal a mathematician on didactics and curriculum theory. Journal of Curriculum Studies, 32, no. 6, p. 777-796, 2000.

GUZMAN, Virginia; BAROZET, Emmanuelle; MÉNDEZ, María Luisa. Legitimation and critique of inequality: a pragmatic approach. Convergencia: Revista de Ciencias Sociales, n. 73, 2017, Universidad Autónoma del Estado de México

GUTSTEIN, Eric. Teaching and learning mathematics for social justice in an urban, latino school. Journal for Research in Mathematics Education, Vol. 34, No.1, pp. 37-73, 2003.

Connecting community, critical and classical knowledge in teaching mathematics for social justice. The Montana Mathematics Enthusiast, Monograph 1, pp. 109-118, 2007.

GUTIÉRREZ, Kris D.; ROGOFF, Barbara. Cultural ways of learning: individual traits or repertorie of practice. In: Educational Researcher, Vol. 32, No. 5, pp. 19-25. 2003.

GUTIÉRREZ, Rochelle. Enabling the practice of mathematics teachers in context: Towards a new equity research agenda. In: Mathematical Thinking and Learning. Vol.4, No. 2-3, pp. 145-187, 2002. 
GUTIÉRREZ, Rochelle. The sociopolitical turn in mathematics education. In: Journal for Research in Mathematics Education. Vol. 44, No 1, pp. 37-68, 2013 a.

GUTIÉRREZ, Rochelle. Why (urban) mathematics teachers need political knowledge. In: Journal of Urban Mathematics Education. Vol.6, No. 2, pp.7-19, 2013 b.

HALL, Stuart. A identidade cultural na pós-modernidade. 11 ed. Rio de Janeiro: DPeA, 2006.

HABERMAS, Jürgen. O espaço público, 30 anos depois. Tradução de Felipe Chanial. 1990.

HARDT, Michael; NEGRI, Antonio. Multidão: guerra e democracia na era do império. Tradução de Clóvis Marques. Rio de Janeiro: Record, 2005.

HARDY, Godfrey H. Em defesa de um matemático. São Paulo: Martins Fontes, 2000.

HARVEY, David. La condición de la posmodernidad. Investigación sobre las orígenes del cambio cultural. Tradução Martha Eguía. Buenos Aires: Amorrortu Editores, 1998.

HARVEY, David. A brief history of neoliberalism. Nova lorque: Oxford, 2005.

HEIDDEGER, Martin. O ser e o tempo. Parte I. Petrópolis: Editora Vozes, 2005.

ILLICH, Ivan. Sociedade sem escolas. Tradução de Lúcia Mathilde Endlich Orth. 7 ed. Petrópolis: Vozes, 1985

INNERARITY, Daniel. A filosofia como uma das belas artes. Lisboa: Teorema, 2007.

JONES, Graham. LANGRALL, Cynthia. THORNTON, Carol. NISBET, Steven. Elementary students' acess to powerful mathematical ideas. In: ENGLISH, Lyn D. 3rd Handbook of International Research in Mathematics Education. New Jersey: Lawrence Earlbaum Associates, 2002. 
KEITEL, Christine. Mathematics, knowledge and political power. In: MAASZ, J., SCHLOEGLMANN, W. (Eds.). New mathematics education research and practice. Dordrecht: Sense Publishers, 2006.

KILPATRICK, Jeremy. Fincando estacas: uma tentativa de demarcar a Educação Matemática como campo profissional e científico. In: Revista Zetetiké. v.4, n.5. Campinas: UNICAMP, 1996.

KLINE, Morris. O fracasso da matemática moderna. São Paulo: Ibrasa, 1976.

KRIPKA,Rosana Maria Luvezute; SCHELLER, Morgana; BONOTTO, Danusa de Lara. Pesquisa documental: considerações sobre conceitos e características na pesquisa qualitativa. In: Congresso IberoAmericano em Investigação Qualitativa, 4, Agosto de 2015. Atas.

LADSON-BILLINGS, Gloria. Toward a theory of culturally relevant pedagogy. In: American Educational Research Journal, Vol. 32, No. 3 , pp. 465-491. Washington: American Educational Research Association, 1995 a.

LADSON-BILLINGS, Gloria. But that's just good teaching! The case for culturaly relevant pedagy. In: In: Theory into practice, Vol. 34, No. 3, pp. 159-165. Ohio: The Ohio State University, 1995 b.

LANGRALL, Cynthia W.; JONES, Graham A.; NISBET, Steven. Elementary students' access to powerful mathematical ideas. In: ENGLISH, Lyn D. Handbook of International Research in Mathematics Education. New Jersey: Lawrence Earlbaum Associates, 2002.

LAVE, Jean. Cognition in practice. Cambridge: Cambridge University Press, 1988.

A selvajeria da mente domesticada. Revista Crítica de Ciências Sociais, n.46, 1996.

Aprendizagem como na prática. In: Horizontes Antropológicos, ano 21, n. 44 Porto Alegre: 2015.

LAVE, Jean; WENGER, Etienne. Situated learning: legitimate peripheral participation. Nova lorque: Cambridge, 1991. 
LEEUWEN, Theo Van. Discourse and practide: new tools for critical discourse analysis. Nova lorque: Oxford University Press, 2008.

LEONEL, Zélia. Contribuição à história da escola pública: elementos para a crítica da teoria liberal da educação. Tese (Doutorado em Educação) - Faculdade de Educação da Universidade Estadual de Campinas. Campinas, p.258, 1994.

LERMAN, Stephen. The social turn in mathematics education research. In: BOALER, Jo. (ed.) Multiple perspectives on mathematics teaching and learning. p.19-44. Ablex: Westport, 2000.

LIBÂNEO, José Carlos. O dualismo perverso da escola pública brasileira: escola do conhecimento para os ricos, escola do acolhimento social para os pobres. Educação e Pesquisa, São Paulo, v. 38, n. 1., p.13-28, jan./mar., 2012.

LÖWY, Michel. Ideologias e ciência social: elementos para uma análise marxista. 19 ed. São Paulo: Cortez, 2010.

LUZURIAGA, Lorenzo. Historia de la educacion y de la pedagogia. 9 ed. Buenos Aires: Editorial Losada, 1971.

LYOTARD, Jean-François. A condição pós moderna. Tradução de Ricardo Corrêa Barbosa. 15 ed. Rio de Janeiro: José Olympio, 2013.

MALLOY, Carol. Democratic access to Mathematics through democratic education: an introduction. In: ENGLISH, Lyn D. Handbook of International Research in Mathematics Education. p.17-25. New Jersey: Lawrence Earlbaum Associates, 2002.

MARSHALL, Thomas Humprey. Cidadania, classe social e status. Rio de Janeiro: Zahar, 1967.

MELO, Cristiane. Estudo sobre a utilização da legislação educacional e da imprensa periódica como fontes para a história da educação. In: Reunião científica regional da ANPED. Curitiba: UFPR, 2006.

MIORIM, Maria Ângela. Introdução à história da Educação Matemática. São Paulo: Atual, 1998. 
MIORIN, Maria Ângela; MIGUEL, Antônio; FIORENTINI, Dario. Ressonâncias e dissonâncias do movimento pendular entre álgebra e geometria no currículo escolar brasileiro. Zetetiké, Campinas, Ano I, n. $1,1993$.

MORENO, Arley R. Wittgenstein através das imagens. Campinas: UNICAMP, 1993.

MORENO-ARMELLA, Luis; BLOCK, David. Democratic access to powerful mathematics in a developing country. In: ENGLISH, Lyn D. Handbook of International Research in Mathematics Education. p. 301-321. New Jersey: Lawrence Earlbaum Associates, 2002.

MOTA Jr., William Pessoa da; MAUÉS, Olgaíses Cabral. O banco mundial e as políticas educacionais brasileiras. Educação e Realidade, Porto Alegre, v.39, n.4, p. 1137-1152, out./dez., 2014.

NEGRI, Antonio. Cinco lições sobre império. Rio de Janeiro: DPeA, 2003.

NISS, Mogens. The concept and role of theory in mathematics education. In: NORMA, 5, 2006, Trondheim. Artigo.

NÓVOA, António. Professores: imagens do futuro presente. Lisboa: Educa, 2009.

OECD. Brazil Country Note. Results from PISA 2012. Disponível em: $<$ http://download.inep.gov.br/acoes_internacionais/pisa/resultados/2013 /country_note_brazil_pisa_2012.pdf $>$. Acessado em 10 de fevereiro de 2014.

OLLAIK, Leila Giandoni; ZILLER, Henrique Moraes. Concepções de validade em pesquisas qualitativas. Educação e Pesquisa, São Paulo, v.38, n.1, p. 229-241, 2012 .

O'RILL, Robert. Mathematics, Numeracy and Democracy. In: NCTM. Mathematics and democracy. The case for quantitative literacy. Estados Unidos da América: The Woodrow Wilson National Fellowship Foundation, 2001.

PAIS, Alexandre; STENTOFT, Diana; VALERO, Paola. From questions of how to questions of why in mathematics education research. In: INTERNATIONAL MATHEMATICS EDUCATION AND SOCIETY CONFERENCE, 6, 2010, Berlim. Proceedings. v. 2, p. 398-407. 
PERONI, Vera. A relação público/privado e a gestão da educação em tempos de redefinição do papel do Estado. In: ADRIÃO, Teresa; PERONI, Vera (orgs.). Público e privado na Educação: novos elementos para o debate. São Paulo: Xamã, 2008.

PERRY, Bob; DOCKETT, Sue. Young children's access to powerful mathematical ideas. In: ENGLISH, Lyn D. Handbook of International Research in Mathematics Education. New Jersey: Lawrence Earlbaum Associates, 2002.

PETITAT, Andre. Produção da escola/produção da sociedade: análise sócio-histórica de alguns momentos decisivos da evolução escolar no ocidente. Trad. Eunice Gruman. Porto Alegre: Artes Médicas, 1994.

PIMENTEL, Alessandra. O método da análise documental: seu uso numa pesquisa historiográfica. Cadernos de Pesquisa, São Paulo, n.114, p.179-195, nov., 2001.

PLATÃO. Menon. São Paulo: Loyola, 2001.

POPKEWITZ, Thomas. The alchemy of the mathematics curriculum: inscriptions and the fabrication of the child. American Educational Research Journal. v.41, n.1, p.3-34, 2004.

abjeção: diferença e construção da desigualdade. Educação e Realidade, Porto Alegre, v.35, n.3, p.77-98, set./dez., 2010.

RAWLS, John. Uma teoria da justiça. Tradução de Almiro Pisetta e Lenita M. R. Esteves. São Paulo: Martins Fontes, 2000.

RISCAL, Sandra A. Política educacional, justiça distributiva e equidade: considerações sobre as políticas compensatórias para a educação. Revista HISTEDBR On-line, Campinas, n.44, p.248-261, dezembro 2011.

ROJANO, Teresa. Mathematics learning in the Junior Secondary School: students' access to significant mathematical ideas. In: ENGLISH, Lyn D. Handbook of International Research in Mathematics Education. New Jersey: Lawrence Earlbaum Associates, 2002. 
ROQUE, Tatiana. História da matemática: desfazendo mitos e lendas. Rio de Janeiro: Zahar, 2012.

SANTOS, Boaventura de Sousa. Introdução a uma ciência pósmoderna. Rio de Janeiro: Graal, 2010

SANTOS, Milton. Por uma outra globalização. 10 ed. Rio de Janeiro: Record, 2002.

SANTOS, Vinicio de Macedo. A matemática escolar, o aluno e o professor: paradoxos aparentes e polarizações em discussão In: Caderno Cedes, Campinas, v. 28, n. 74, pp. 25-38, jan./abr, 2008.

SANTOS, Boaventura de Sousa; CHAUÍ, Marilena. Direitos humanos, democracia e desenvolvimento. São Paulo: Cortez, 2013.

SAVIANI, Demerval. Escola e democracia. 38 ed. Campinas: Autores Associados, 2006.

- Aberturas para a história da educação. Do debate teórico-metodológico no campo da história ao debate sobre a construção do sistema nacional de educação no Brasil. Campinas: Autores Associados, 2013 a.

. História das ideias pedagógicas no Brasil. 4 ed. Campinas: Autores Associados, 2013 b.

- lunar de Sepé. Paixão, dilemas e perspectivas na educação. Campinas: Autores Associados, 2014.

SAVIANI, Demerval; ALMEIDA, Jane Soares de; SOUZA, Rosa Fátima; VALDEMARIN, Vera Teresa. O legado educacional do século XIX no Brasil. 3 ed. Campinas: Autores Associados, 2014 a.

SAVIANI, Demerval; ALMEIDA, Jane Soares de; SOUZA, Rosa Fátima; VALDEMARIN, Vera Teresa. O legado educacional do século XX no Brasil. 3 ed. Campinas: Autores Associados, 2014 b.

SCHLIEMANN, Analucia D. Escolarização formal versus experiência prática na resolução de problemas. In: CARRAHER, T., CARRAHER, D., SCHLIEMANN, A. Na vida dez, na escola zero. São Paulo: Cortez, 2006. 
SCHUBRING, Gert. Análise histórica de livros de matemática: notas de aula. Tradução de Maria Laura Magalhães Gomes. Campinas: Autores Associados, 2003.

SENNETT, Richard. A cultura do novo capitalismo. Tradução de Clóvis Marques. Rio de Janeiro: Record, 2006.

SHARMA, Sashi. Qualitative approaches in mathematics educatio research: challenges and possible solutions. Education Journal, v.2, n.2, p.50-57, 2013.

SILVA, Josué Pereira. Repensando a relação entre trabalho e cidadania social. São Paulo em Perspectiva, São Paulo, v.4, n.9, 1995.

SILVA, Roberto. Fundamentos teóricos e metodológicos da pedagogia social no Brasil. In: Congresso Internacional de Pedagogia Social, 1, 2006, Anais.

SILVA, Alexandre. Meritocracia, educação matemática: um estudo relacional. Tese (Doutorado em Educação) - Faculdade de Educação da Universidade Estadual de Campinas. Campinas, p.229, 2013.

SKOVSMOSE, Introduction to the section: mathematics, culture and society. In: MAASZ, Jürgen; SCHLOEGLMANN, Wolfgang (Eds.). New mathematics education research and practice. Dordrecht: Sense Publishers, 2006.

SKOVSMOSE, Ole; VALERO, Paola. Democratic access to powerful mathematical ideas. In: ENGLISH, Lyn D. Handbook of International Research in Mathematics Education. p. 383-407. New Jersey: Lawrence Earlbaum Associates, 2002.

SKOVSMOSE, Ole; VALERO, Paola; SCANDIUZZI, Pedro Paulo; ALR $\varnothing$, Helle. A aprendizagem matemática de uma posição de fronteira. Foregrounds e intencionalidade de estudantes de uma favela brasileira. Bolema. Rio Claro, v. 26, n. 42, p. 231-260, abril, 2012.

TATE, William. Returning to the Root: A Culturally Relevant Approach to Mathematics Pedagogy. Theory into practice, Ohio, v. 34, n. 3, p. 166 $173,1995$.

TATE, William; ROUSSEAU, Celia. Access and opportunity: the political and social context of mathematics education. In: ENGLISH, Lyn D. 
Handbook of International Research in Mathematics Education. p. 269-299. New Jersey: Lawrence Earlbaum Associates, 2002.

TORRES, Carlos Alberto. A pedagogia política de Paulo Freire. In: TORRES, Carlos Alberto (org.). Teoria crítica e sociologia política da educação. Tradução de Maria José do Amaral Ferreira. São Paulo: Cortez, 2003.

UNESCO. Declaração mundial sobre educação para todos: satisfação das necessidades básicas de aprendizagem. UNESCO, 1998.

Declaração de Nova Delhi sobre Educação para Todos Nova Delhi, 6 de dezembro de 1993. UNESCO, 1998.

Constituição da Organização das Nações Unidas para a Ē ducação, a Ciência e a Cultura. Brasília: UNESCO Brasília Office, 2002.

VALDERRAMA, Fernando. A history of UNESCO. Paris: UNESCO Publishings, 1995.

VALERO, Paola. Consideraciones sobre el contexto y la educación matemática para la democracia. Quadrante, Lisboa, v. 11, n. 1, p. 4959, jan./jun., 2002.

Capital humano: o currículo de matemática escolar e a fabricação do homus oeconomicus liberal. In: Fórum Nacional de Currículos de Matemática, 4, 2017, São Paulo. No prelo.

VALLE, Ione Ribeiro. Uma escola justa contra o sistema de multiplicação das desigualdades sociais. Educar em Revista. Curitiba, n.48, p. 289-307, abr./jun. 2013.

VILELA, Denise $S$. Usos e jogos de linguagem na matemática. Diálogos entre filosofia e educação matemática. São Paulo: Livraria da Física, 2013.

VILELA, Denise S., MIGUEL, Antonio, MOURA, A. R. Desconstruindo a matemática escolar sob uma perspectiva pós-metafísica de educação. Zetetiké, v.18, Número Temático. Campinas, 2010. 
indisciplinar de uma prática cultural numa perspectiva wittgensteiniana. Revista Reflexão e Ação, v.20, n2, p.06-31, jul./dez. Santa Cruz do Sul, 2012. WEBER, Max. Economia e sociedade. Fundamentos da sociologia compreensiva. Vol. 2. São Paulo: Imprensa Oficial, 2004.

WALKERDINE, Valerie. The mastery of reason. London: Routledge, 1988.

WALKERDINE, Valerie. Redefining the subject in situated cognition theory. In: KIRSHNER, David; WHITSON, James A. (Eds.) Situated cognition: Social, semiotic and psychological perspectives. Mahwah: Lawrence Erlbaum, 1997.

WALZER, Michael. Spheres of justice: a defense of pluralism and equality. New York: Basic Books, 1983.

WENGER, Etienne. Communities of practice: learning, meaning and identity. New York: Cambridge, 1998.

WERTSCH, James $V$. The concept of activity in soviet psychology. Armonk: M. E. Sharpe, 1981.

WILLIANS, Raymond. Palabras clave: un vocabulario de la cultura y la sociedad. Buenos Aires: Nueva Visión, 2003.

WITTGENSTEIN, Ludwig J.J. Investigações filosóficas. Coleção Os Pensadores. São Paulo: Ed. Nova Cultural, 1999.

mathematics. Sussex: The Harverster Press, 1976.

Remarks on the foundations of mathematics. Massachusetts: The M.I.T. Press, 1967. 